TRAFFIC SIGNAL COORDINATION FOR WELLINGTON STREET WEST, TORONTO, ONTARIO

by

Sharareh Shadbakhsh,

B.Eng., Ryerson University, 2014

\author{
A Project \\ presented to Ryerson University \\ in partial fulfillment of the \\ requirements for the degree of \\ Master of Engineering \\ in the Program of \\ Civil Engineering
}

Toronto, Ontario, Canada, 2017

(C)Sharareh Shadbakhsh, 2017 


\section{Author's Declaration}

I hereby declare that I am the sole author of this MRP. This is a true copy of the MRP, including any required final revisions.

I authorize Ryerson University to lend this MRP to other institutions or individuals for the purpose of scholarly research.

I further authorize Ryerson University to reproduce this MRP by photocopying or by other

means, in total or in part, at the request of other institutions or individuals for the purpose of scholarly research.

I understand that my MRP may be made electronically available to the public. 


\title{
TRAFFIC SIGNAL COORDINATION FOR WELLINGTON STREET WEST, TORONTO, ONTARIO
}

\author{
Sharareh Shadbakhsh \\ Master of Engineering, 2017 \\ Civil Engineering, Ryerson University \\ Toronto, Canada
}

\begin{abstract}
The increasing volume of traffic in cities has a significant effect on road traffic congestion and the travel time it takes for road users to reach their destinations. Coordinating traffic signals, which is a system of light that cascade in sequence where a platoon of vehicles can travel through a continuous series of green light without stopping, can improve the driver's experience significantly. This report covers the development of a coordinated traffic signal system along Wellington Street West from Church Street to Blue Jays Way Street as part of a City of Toronto signal coordination project. The objective of this study is to improve coordination through modification of signal timing plans while maintaining reasonably minimal impacts to the side street levels of service and delays. The overall goal is to reduced travel times, delays, number of stops and fuel consumption, resulting in public benefit.
\end{abstract}




\section{Acknowledgments}

I would like to thank the team at the City of Toronto, especially Rajanath Bissessar, Hao Le, and Darryl Spencer, for providing me with the support, training, data and topic for the project undertaken for this report. I would also like to thank Dr. Bhagwant Persaud for being my graduate student advisor over the last two years and Rachel Peluso for the administrative help throughout my time at Ryerson. Lastly, I would like to thank Dr. Sognlian Li, Dr. Arnold Yuan and Dr. Bhagwant Persaud for evaluating this report. 


\section{Table of Contents}

























2.1.4 Posted Speed Limit.....................................................................................................





2.1.7 Pedestrian and Cyclist Activities ................................................................................. 4

2.1.8 Construction Area - Temporary Construction Timings.................................................... 4





2.3.1 Travel Time and Delay Study Analysis......................................................................... 5

3. Base Synchro Model Development and Adjustments ...............................................................8



4. Calibration Methodology and Validation of the Synchro Model ............................................10



4.1.1 Intersections with On-Street Parking ......................................................................... 14





5.1 Methodologies for Signal Optimization ............................................................................... 18

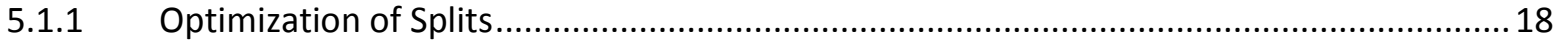







$6.1 \quad$ Intersection and Movement Traffic Operations ..................................................................... 21 


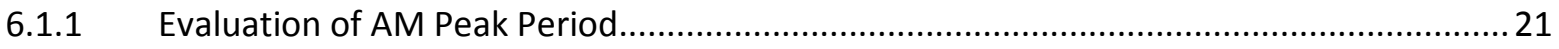

6.1.2 Evaluation of PM Peak Period Alternatives ................................................................. 22

6.1.3 Evaluation of OFF Peak Period Alternatives.................................................................. 22













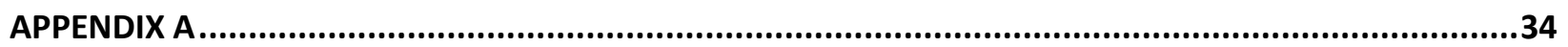





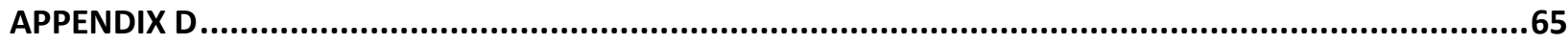





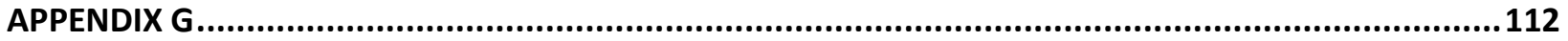

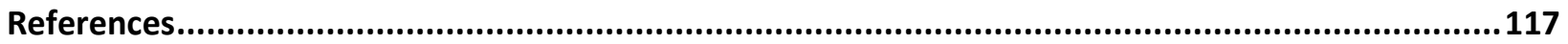




\section{List of Tables}







Table 4: Calibration Assumption for PM peak ..................................................................................... 12







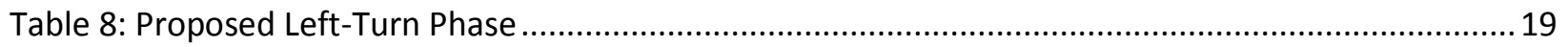









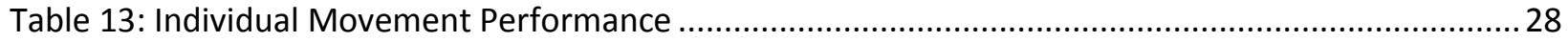



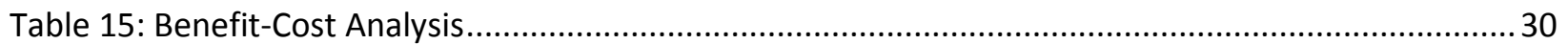




\section{List of Figures}



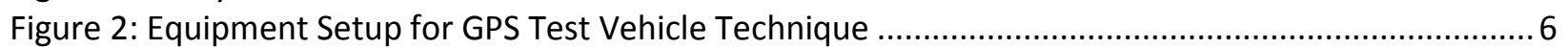







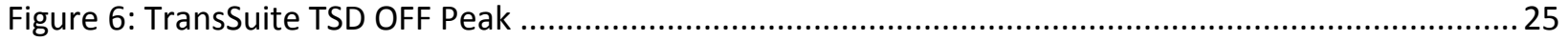






\section{List of Appendices}

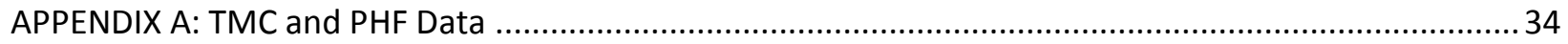

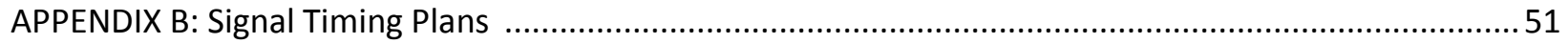

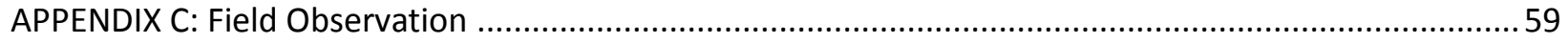

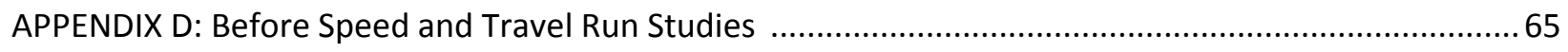



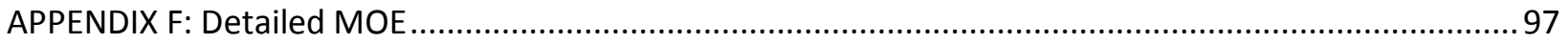

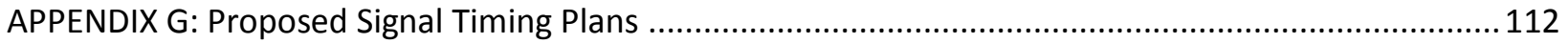




\section{Introduction}

Traffic signal progression or coordination aims to provide a wave of "green lights" on corridors. Under the direction of the City of Toronto, this study was completed to improve the coordination of traffic signals along Wellington Street West from Church Street to Blue Jays Way Street.

The objective of this report is to analyze the existing conditions in terms of traffic flow and traffic operation. It further identifies deficiencies and provides solutions to improve the measure of effectiveness. This goal would be accomplished by conducting a comprehensive study of the existing conditions as well as developing alternative analysis along with recommendations on new signal timings for the study corridor. The study corridor includes 8 signalized intersections as illustrated in Figure 1.

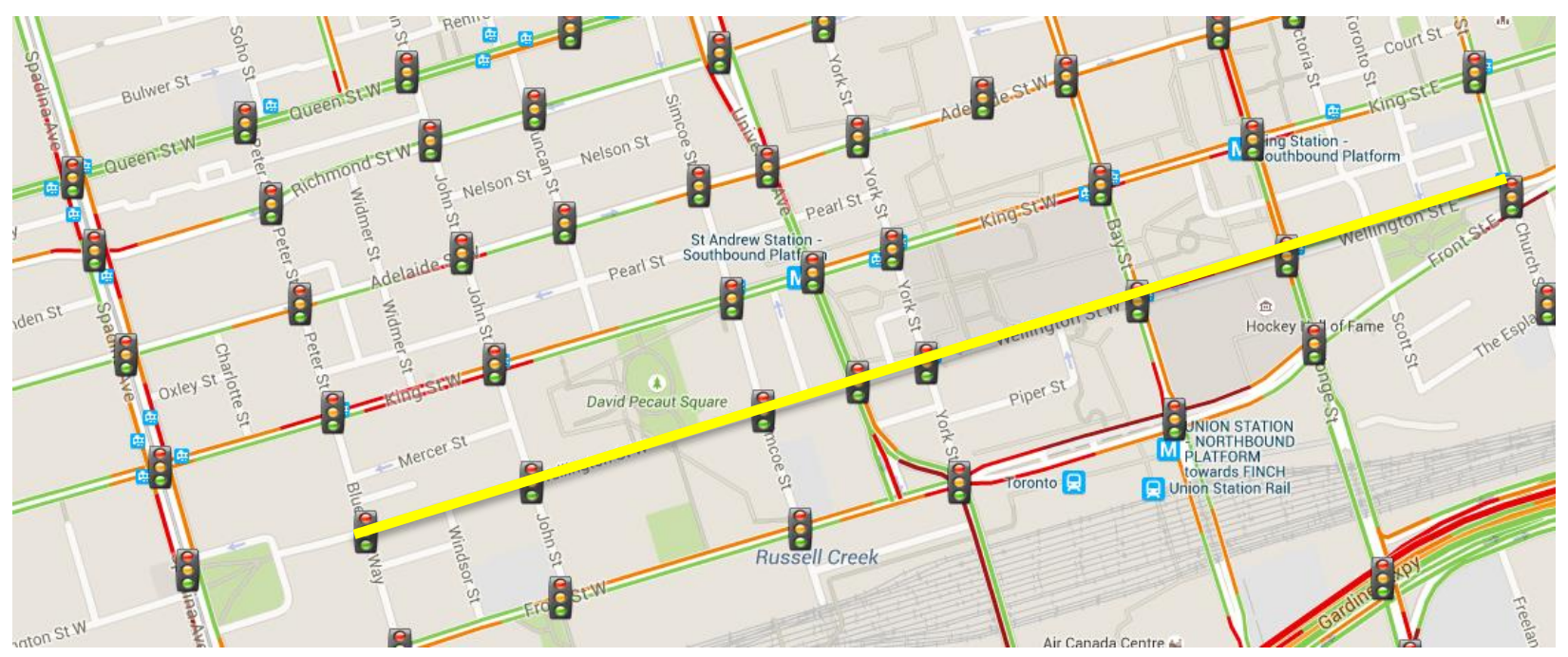

Figure 1:Study Area

All the intersections in this study are operating under TransSuite control system. TransSuite traffic control system is a family of transportation management software products. It relies on a second-by-second communication system that also displays real-time graphical information. It depends on site equipment where it can maintain coordination up to one day in its memory in case of communication loss. TransSuite does not control the traffic movements by itself; however, it sends commands to the controller to follow the timing plans [1]. 
City of Toronto uses six mode of control to operate traffic signal that includes: fully-actuated (FA), fixed-time (FXT), semi-actuated (SA), semi-actuated pedestrian (SAP), semi-actuated vehicle (SAV), and pedestrian-actuated (PED). The mode of control (MOC) for intersections is all of fixed (FXT) type. Mode of control of an intersection refers to the type signal operation. The mode of control at City of Toronto is determined based on the off-peak vehicle and pedestrian volume. The fixed mode of operation refers to an automatic change of signal direction from the main street to side street and vice versa [2]. Detailed intersection information is shown in Table 1.

\begin{tabular}{|l|l|l|l|l|l|l|}
\hline PX\# & $\begin{array}{c}\text { Intersection } \\
\text { Name }\end{array}$ & $\begin{array}{c}\text { Distance } \\
\text { (Approx.) } \\
\mathbf{M}\end{array}$ & $\begin{array}{c}\text { Speed } \\
\text { Limit } \\
\mathbf{k m} / \mathbf{h r}\end{array}$ & MOC & $\begin{array}{c}\text { Existing } \\
\text { CONTROL } \\
\text { SYSTEM }\end{array}$ & \multicolumn{1}{c|}{$\begin{array}{c}\text { Controller } \\
\text { TYPE }\end{array}$} \\
\hline 15 & CHURCH ST & 294 & 50 & FXT & TransSuite & Econolite ASC/3-2100 \\
\hline 30 & YONGE ST & 200 & 50 & FXT & TransSuite & PEEK ATC-1000 \\
\hline 60 & BAY ST & 280 & 50 & FXT & TransSuite & Econolite ASC/3-2100 \\
\hline 71 & YORK ST & 85 & 50 & FXT & TransSuite & Econolite ASC/3-2100 \\
\hline 76 & UNIVERSITY AVE & 120 & 50 & FXT & TransSuite & PEEK ATC-1000 \\
\hline 264 & SIMCOE ST & 309 & 50 & FXT & TransSuite & Econolite ASC/3-2100 \\
\hline 1489 & JOHN ST & 210 & 50 & FXT & TransSuite & Econolite ASC/3-2100 \\
\hline 1682 & BLUE JAYS WAY & START & 50 & FXT & TransSuite & Econolite ASC/3-2100 \\
\hline
\end{tabular}

Table 1: Wellington Street -Control area spreadsheet

To successfully achieve the project goal, the work was divided into 7 major tasks that are listed below:

Task 1 - Project Planning and Preparation;

Task 2 - Data Collection;

Task 3 - Speed and Delay Run Surveys;

Task 4 - Base Model Development and Calibration

Task 5 - Optimization, Alternative Analysis, and Recommendations

Task 6 - Review and Quality Assurance

Task 7 - Final Report

The focus of this report is on detail summary of task 2 to task 5 findings. 


\section{Data Collection Review and Site Observation}

\subsection{Data Collection Review}

\subsubsection{Turning Movement Counts}

The Turning Movement Counts (TMCs) were provided by the Traffic Safety Unit (TSU) at the City of Toronto. Refer to Appendix A for the summarized TMCs and Peak Hour Factors (PHF). The traffic movement counts data for many of intersections were older than two years, so comprehensive volume balancing was conducted to account for imbalanced volumes. Details on volume balancing can be found in section 3.1.

\subsubsection{Traffic Signal Timing Plans}

Signal timing plans were collected from the in-house Pedestrian Crossing (PX) folders. The PX folders contain a comprehensive history of each of the signalized intersection. Every PX number corresponds to a unique intersection with information including signal timing plans, public request for review of the timing plan and other events that have contributed to the current state of the intersection and signal timing plans.

These signal timing plans were used in the development of the base Synchro model. Signal timings for the study intersections are provided in Appendix B.

\subsubsection{Intersection Drawings}

The intersection drawings were collected from available PX folders in the ITS department cabinets, since no electronic version of these drawing were available. Google Earth and Mirasan tools were used to verify the critical distances, lane configuration, and storage lengths. Field measurements were done at the locations where inconsistency was observed.

\subsubsection{Posted Speed Limit}

The posted speed limit along Wellington Street West from Church Street to Blue Jays Ways Street is $50 \mathrm{~km} / \mathrm{h}$. 


\subsubsection{Adjacent Land Uses}

Wellington Street passes through the Financial and Entertainment districts. These consist of commercial, institutional and open space land uses.

\subsubsection{On-Street Parking}

Generally, on-street parking is prohibited during rush hour for most of the intersections, however, taxi stands are provided between Bay Street and York Street during rush hour.

\subsubsection{Pedestrian and Cyclist Activities}

The presences of pedestrian and cyclist are notable in the following intersections which can be found in TMC tables in Appendix A:

- Bay Street at Wellington

- York Street at Wellington

\subsubsection{Construction Area - Temporary Construction Timings}

Temporary construction of condominium building was taking near the north side of the Yonge and Wellington intersection. The westbound right turn lane was fully occupied with construction and site materials, resulting in reduced number of lanes for westbound movements. This observations were taken into account for a more accurate model calibration.

\subsection{Field Observations}

The focus of the observation during AM, OFF and PM peaks was to identify locations with queue spillback, queue blockages, significant long queues, stop-and-go conditions, high pedestrian activity, pedestrian impedance, long delays generated by transit vehicles, and approaches and movements where vehicles required more than one cycle to pass through the intersection.

Consideration for the implementation of advance left-turn phases will be made, based on observations, and later confirmed within the Synchro model. Field observations were completed by the author of this report in April 2015. Details of field observation can be found in Appendix C. 


\section{3 "Before" Travel Run Study}

In order to create a baseline for the existing traffic condition, travel run and delay survey were conducted in the west directions of the Wellington Street. A minimum of 5 runs per direction, per period, per day, was required. This resulted in a total of 15 runs per direction, per period. The 'before' runs were conducted on the following two weekdays:

- Tuesday, April 21/2015

- Wednesday, April 22/2015

By reviewing the available intersection turning movement count data the 'before' runs and delay survey were conducted during the following time periods on each day:

- AM Peak: 7:00 - 9:30

- Off Peak: 10:30 - 14:30

- PM Peak: 15:30 - 6:30

\subsubsection{Travel Time and Delay Study Analysis}

This section focuses on the study of corridor travel time and delay using Global Positioning System (GPS) and Test Vehicle Techniques. The travel time study provides information and data on the amount of time it takes to travel a segment of a road. In conducting the travel time study the "floating car method" was applied using GPS equipment and software illustrated in Figure 2. With the "floating car method", drivers attempt to travel with the flow of traffic by changing lanes to pass as many cars as they are passed by [3]. 


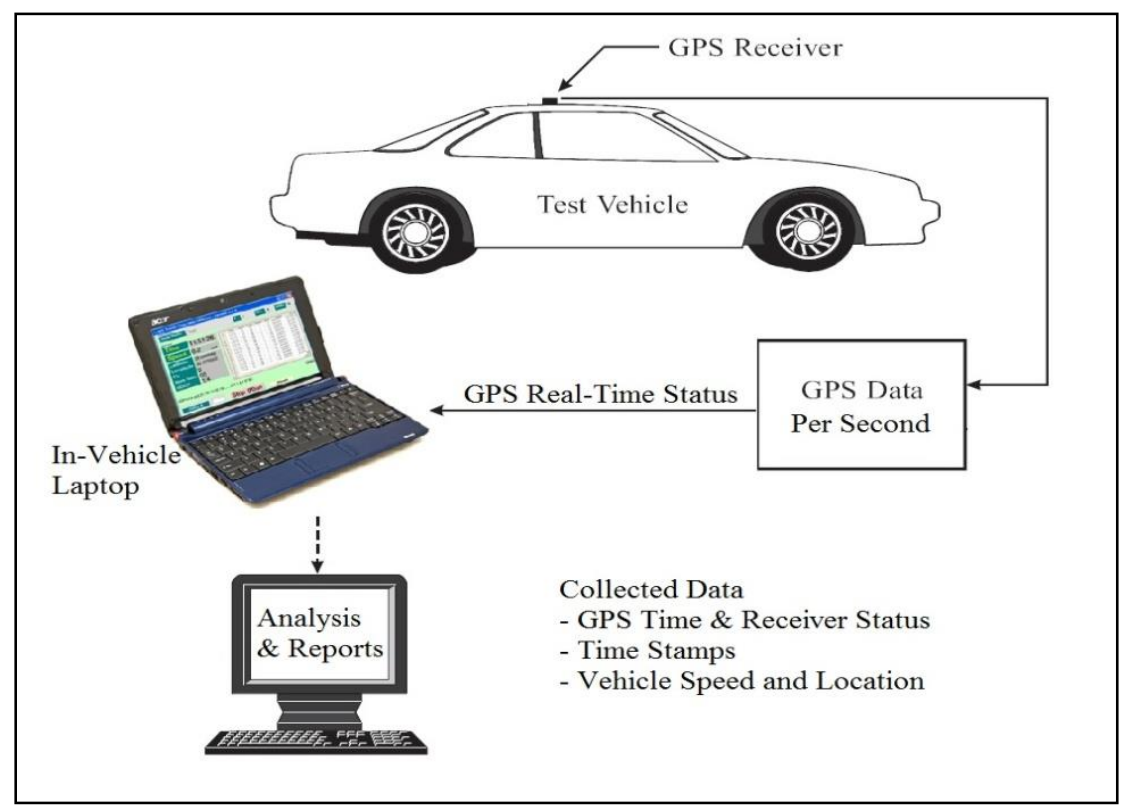

Figure 2: Equipment Setup for GPS Test Vehicle Technique

As five to six runs per direction per peak period per day was the requested minimum sample size for the busiest two hours, some runs with partial lane blockage were still included in the delay analysis. To ensure that the travel time variances caused by partial lane blockages were acceptable in the delay analysis, the confidence level of each survey study per direction per peak period (i.e., 15 runs) was reviewed. In this study, PC-Travel software was used for travel time and delay analysis with the source of GPS data collection [4]. Based on the confidence level calculations in PC-Travel software, the 'before' surveys obtained a sufficient sample size (i.e., 15 runs) that realized $95 \%$ confidence (permitted error of approximately $2.0 \mathrm{~km} / \mathrm{h}$ to $5.0 \mathrm{~km} / \mathrm{h}$ ). [3]

Appendix D provides the reports generated by the PC-Travel software. These reports record the following four traffic performance (MOEs) from the 'before' survey:

- Travel time - time required to travel between upstream and downstream intersection measured from stop bars;

- Average speed - average speed recorded between upstream and downstream intersection;

- Stops - average number of times that the vehicle speed dropped below $8 \mathrm{~km} / \mathrm{h}$; and

- Total delay - total time recorded when the vehicle speed dropped below the normal travel speed of $50 \mathrm{~km} / \mathrm{h}$.

The average field measurements of the MOEs are summarized in 
Table 2: PC Travel output data of Field Study

\begin{tabular}{|c|c|c|c|c|c|c|}
\hline Peak Period & Movement & Node & $\begin{array}{c}\text { Travel } \\
\text { Time }\end{array}$ & Number of Stops & AVG Speed & Total Delay \\
\hline \multirow{9}{*}{ AM } & \multirow{27}{*}{ WB } & Church & 52.5 & 0.7 & 13.2 & 40.5 \\
\hline & & Yonge & 85.7 & 1.7 & 12.1 & 68.5 \\
\hline & & Bay & 64.3 & 0.8 & 11.3 & 52.3 \\
\hline & & York & 47.3 & 1 & 21.7 & 30.3 \\
\hline & & University & 17.8 & 0.3 & 8.1 & 15.3 \\
\hline & & Simcoe & 28.3 & 0.5 & 12.4 & 22.2 \\
\hline & & John & 50.8 & 0.8 & 20.1 & 33.3 \\
\hline & & $\begin{array}{c}\text { Blue Jays } \\
\text { Way }\end{array}$ & 30.3 & 0.3 & 25.8 & 17.2 \\
\hline & & Total & 377 & 6.1 & 124.7 & 279.6 \\
\hline \multirow{9}{*}{ OFF } & & Church & 50.2 & 1 & 9.5 & 42.2 \\
\hline & & Yonge & 49.6 & 0.8 & 21.4 & 31.6 \\
\hline & & Bay & 48.4 & 0.8 & 15.5 & 35.4 \\
\hline & & York & 62.4 & 2.4 & 14.1 & 47.4 \\
\hline & & University & 22.8 & 0.4 & 14.2 & 17.2 \\
\hline & & Simcoe & 33.2 & 0.6 & 13.3 & 25.4 \\
\hline & & John & 54.2 & 0.8 & 19.8 & 36 \\
\hline & & $\begin{array}{c}\text { Blue Jays } \\
\text { Way }\end{array}$ & 42.6 & 0.63 & 17.4 & 30 \\
\hline & & Total & 363.4 & 7.43 & 125.2 & 265.2 \\
\hline \multirow{9}{*}{ PM } & & Church & 76 & 1.3 & 8.1 & 65.5 \\
\hline & & Yonge & 59 & 1 & 18.5 & 40.8 \\
\hline & & Bay & 45.3 & 1 & 15.3 & 33.3 \\
\hline & & York & 88.8 & 2.3 & 10.3 & 73.3 \\
\hline & & University & 32.8 & 0.5 & 8.4 & 27.8 \\
\hline & & Simcoe & 16.8 & 0.3 & 23.3 & 9.8 \\
\hline & & John & 42.5 & 0.5 & 17.4 & 25.5 \\
\hline & & $\begin{array}{c}\text { Blue Jays } \\
\text { Way }\end{array}$ & 43.5 & 1 & 28.2 & 31.5 \\
\hline & & Total & 404.7 & 7.9 & 129.5 & 307.5 \\
\hline
\end{tabular}




\section{Base Synchro Model Development and Adjustments}

To analyze the current traffic signal operations a base model was constructed in Synchro 7 and Simtraffic. Synchro is a macroscopic traffic analysis tool based on the methodology outlined in the Highway Capacity Manual (2000) [5]. It is used for signalized intersections and has the capability to optimize the signal timing and offsets. Simtraffic is a traffic simulation software which performs microsimulation of the expected traffic flows [6].

In this study, the base models were developed for peak periods of AM, OFF Peak and PM during the weekdays only and imported to Synchro software. The purpose was to examine existing operations using current traffic signal phasing and timings, intersection turning movement, traffic count data and other associated road network information. The following shows a summary of steps taken for creating the base Synchro model:

1. All signalized intersection nodes have been added and the intersection spacing has been confirmed using Google Maps.

2. Nodes have been numbered per the PX numbers. Lane configurations at the intersections and pedestrian crossing have been coded based on intersection drawings.

3. The signal timing plans have been coded using the existing TransSuite timing cards available in PX folders.

4. Vehicle volumes have been balanced as explained in Section 3.1

5. Volume parameters have been coded based on traffic counts including pedestrian volumes, cyclists, heavy vehicle percentage and peak hour factor.

6. To reflect the real traffic better, the City's Peak Hour Factor (PHF) reports were inserted for each movement for AM and PM period. However, for the OFF Peak period the PHF number was manually calculated according to the following formula from Highway Capacity Manual (HCM) 2010 [7]:

$$
P H F=\frac{V_{h}}{4 * V_{15 \min }}
$$

Where $V_{h}$ the hourly volume and $V_{15 m i n}$ is the highest 15 -minute count. 
7. Permit Right Turn on Red (RTOR) based on the field regulations

8. The "Referenced to:" field in the Synchro model was adjusted to "Begin of Green:" for all MTSS Controllers, as well as TransSuite Controllers operating Econolite and PEEK 3000. The "Referenced to:" field in the Synchro model was adjusted to "TS2 - 1st Green" for all TransSuite Controllers operating EPAC and PEEK ATC-1000.

\subsection{Volume Balancing}

As part of the Base Synchro Model development, volume balancing between adjacent intersections is required by the City for this project. This step was done using the following methodology as provided by the City:

1. Identify locations that have a volume imbalance greater than $10 \%$

2. Determine land uses and presence of access within the areas where imbalances are greater than $10 \%$

3. Based on the land use, accesses and local knowledge, determine if the imbalance is justified

4. If the imbalance is not justified, then volumes will be balanced using the major/major intersection as a reference for balancing the smaller intersection within $10 \%$, using the following assumptions:

5. If Major/Major volume is greater than adjacent Major/Minor intersection volume, then increase the Major/Minor through volume

6. If Major/Major volume is less than consecutive adjacent Major/Minor intersection volumes, then increase the Major/Major volume

7. If Major/Minor is imbalanced with consecutive adjacent Major/Minors, increase or decrease accordingly

8. In general, Major/Major volumes should not be lowered to accommodate volume balancing

Figure 3 illustrates an example of volume balancing for the off-peak period from the intersection of Church/Wellington to Yonge/Wellington. 


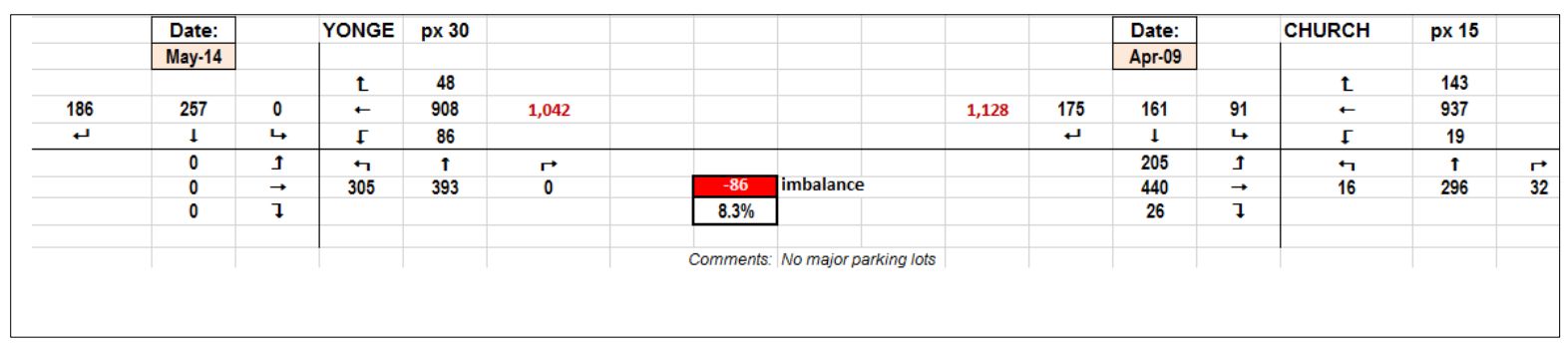

Figure 3: Volume Balancing Example

The imbalance volume of vehicles exiting Church/Wellington and entering Yonge/Wellington is larger than $10 \%$ and, since there is no major access point or justification, volume balancing is conducted by reducing the volume of westbound through movement vehicles by 200 (from 1137 to 937 vehicles) at Church/Wellington. This results in an imbalance of $8.3 \%$ as seen in Figure 3.

It should be noted that volume balancing is only conducted for through movements. Please refer to Appendix $\mathbf{E}$ for all other intersections.

\section{Calibration Methodology and Validation of the Synchro Model}

For the development of the calibrated model, guidelines from City of Toronto [8] and Highway Capacity Manual [7] were used and followed; however, any exception to the procedure and the guidelines are specified in the next section.

\subsection{Calibration}

The base existing Synchro model needs to be calibrated to reflect the observed site conditions. Therefore, intersections with over capacity conditions $(\mathrm{V} / \mathrm{C}<1)$ and poor LOS will be identified for the calibration.

The assumption parameters for the uncalibrated model for all three periods is presented in following tables. Parameters that had influence on V/C ratio include the lane utilization factor, lost time adjustment and movement counts. The next section explains additional adjustments applied to the model. 
Table 3: Calibration Assumption for AM peak

\begin{tabular}{|c|c|c|c|c|c|c|c|c|}
\hline \multirow[t]{2}{*}{ Segment } & \multicolumn{8}{|c|}{ Adjustments } \\
\hline & $\begin{array}{l}\text { Ideal } \\
\text { Sat. } \\
\text { Flow }\end{array}$ & PHF & Lost Time & $\begin{array}{l}\text { Lane } \\
\text { Width }\end{array}$ & $\begin{array}{l}\text { Adjacent } \\
\text { Parking }\end{array}$ & $\begin{array}{l}\text { Bus } \\
\text { Blockage }\end{array}$ & Other & Notes \\
\hline $\begin{array}{l}\text { Church- } \\
\text { Yonge }\end{array}$ & $\begin{array}{l}1700 \\
\text { for WBR }\end{array}$ & $\begin{array}{l}\text { WBL }=0.91, W \\
\text { BT }=0.93, W B R \\
=0.53\end{array}$ & & & & & & $\begin{array}{l}\text { Construction } \\
\text { on The Right } \\
\text { Lane }\end{array}$ \\
\hline Yonge-Bay & 1800 & $\begin{array}{l}\text { WBL }=0.79 \\
W B T=0.97 \\
W B R=0.75\end{array}$ & & & & 4 & & \\
\hline Bay-York & 1700 & $\begin{array}{l}\text { WBT }=0.88, W \\
\mathrm{BR}=0.85\end{array}$ & & $\begin{array}{l}3 m \text { for all } \\
\text { lanes }\end{array}$ & 20 & 4 & & \\
\hline $\begin{array}{l}\text { York- } \\
\text { University }\end{array}$ & $\begin{array}{l}\text { Increase } \\
d \text { to } \\
2005 \\
\text { for WBT } \\
\text { and } \\
\text { WBR } \\
\text { and to } \\
2000 \\
\text { for WBL }\end{array}$ & $\begin{array}{l}\text { Intersection } \\
\text { AVG }=0.93\end{array}$ & $\begin{array}{l}\text { Decreased } \\
\text { to }-2\end{array}$ & & & 4 & & \\
\hline $\begin{array}{l}\text { University- } \\
\text { Simcoe }\end{array}$ & 1800 & $\begin{array}{l}\text { Intersection } \\
\text { AVG }=0.95\end{array}$ & & & & & $\begin{array}{l}\text { Drop } \\
\text { Lane }\end{array}$ & $\begin{array}{l}\text { Location of } \\
\text { DropLane:58 } \\
\mathrm{m} \text { from Left } \\
\& 62 \mathrm{~m} \text { from } \\
\text { Right }\end{array}$ \\
\hline $\begin{array}{l}\text { Simcoe- } \\
\text { John }\end{array}$ & 1800 & $\begin{array}{l}\text { WBL }=0.71 \\
W B T=0.84 \\
W B R=0.87\end{array}$ & & & 15 & & & \\
\hline $\begin{array}{l}\text { John-Blue } \\
\text { Jays Way }\end{array}$ & 1900 & $\begin{array}{l}\text { WBL }=0.73 \\
W B T=0.73 \\
W B R=0.67\end{array}$ & & & 15 & & $\begin{array}{l}\text { *Drop } \\
\text { Lane }\end{array}$ & $\begin{array}{l}\text { 103m from } \\
\text { Left \& } 107 m \\
\text { from Right }\end{array}$ \\
\hline
\end{tabular}




\begin{tabular}{|c|c|c|c|c|c|c|c|c|}
\hline \multirow[t]{2}{*}{ Segment } & \multicolumn{8}{|c|}{ Adjustments } \\
\hline & $\begin{array}{l}\text { Ideal Sat. } \\
\text { Flow }\end{array}$ & PHF & Lost Time & $\begin{array}{l}\text { Lane } \\
\text { Width }\end{array}$ & $\begin{array}{l}\text { Adjacent } \\
\text { Parking }\end{array}$ & $\begin{array}{l}\text { Bus } \\
\text { Blockage }\end{array}$ & Other & Notes \\
\hline $\begin{array}{l}\text { Church- } \\
\text { Yonge }\end{array}$ & 1750 & $\begin{array}{l}\text { WBL }=0.82, W \\
B T=0.87 \\
, W B R=0.82\end{array}$ & & & & 50 & & \\
\hline Yonge-Bay & 1700 & $\begin{array}{l}\text { WBL }=0.77, \mathrm{~W} \\
\mathrm{BT}=0.90, \mathrm{WBR} \\
=0.62\end{array}$ & & & & 30 & 4 & \\
\hline Bay-York & 1800 & $\begin{array}{l}\text { WBT }=0.95, \\
W B R=0.91\end{array}$ & & & $\begin{array}{l}3 \mathrm{~m} \text { for } \\
\text { all lanes }\end{array}$ & 30 & 4 & \\
\hline $\begin{array}{l}\text { York- } \\
\text { University }\end{array}$ & $\begin{array}{l}\text { Increased } \\
\text { to } 2005 \\
\text { for WBT, } \\
\text { WBR and } \\
\text { WBL }\end{array}$ & $\begin{array}{l}\text { WBL }=0.91, W \\
B T=0.90, \\
W B L=0.90\end{array}$ & & $\begin{array}{l}\text { Decreased } \\
\text { to }-3\end{array}$ & & & 4 & \\
\hline $\begin{array}{l}\text { University } \\
\text {-Simcoe }\end{array}$ & 1800 & $\begin{array}{l}\text { WBT }=0.93, W \\
\mathrm{BR}=0.91,\end{array}$ & & & & & & drop lane \\
\hline $\begin{array}{l}\text { Simcoe- } \\
\text { John }\end{array}$ & 1800 & $\begin{array}{l}\text { WBL }=0.71, \mathrm{~W} \\
\mathrm{BT}=0.83, \\
\mathrm{WBR}=0.91\end{array}$ & & & & 10 & & \\
\hline $\begin{array}{l}\text { John-Blue } \\
\text { Jays Way }\end{array}$ & 1800 & $\begin{array}{l}\text { WBL=0.96, } W \\
B T=0.69, \\
W B R=0.74\end{array}$ & & & & 10 & & $\begin{array}{l}\text { added drop } \\
\text { lane using } \\
\text { bend node } \\
\text { and created } \\
\text { offset of }-2 \text { to } \\
\text { account for } \\
\text { left side drop } \\
\text { lane instead of } \\
\text { right }\end{array}$ \\
\hline
\end{tabular}

Table 4: Calibration Assumption for PM peak 


\begin{tabular}{|c|c|c|c|c|c|c|c|c|}
\hline \multirow[t]{2}{*}{ Segment } & \multicolumn{8}{|c|}{ Adjustments } \\
\hline & $\begin{array}{l}\text { Ideal } \\
\text { Sat. } \\
\text { Flow }\end{array}$ & PHF & $\begin{array}{l}\text { Lost } \\
\text { Time }\end{array}$ & $\begin{array}{l}\text { Lane } \\
\text { Width }\end{array}$ & $\begin{array}{l}\text { Adjacent } \\
\text { Parking }\end{array}$ & $\begin{array}{l}\text { Bus } \\
\text { Blockage }\end{array}$ & Other & Notes \\
\hline $\begin{array}{l}\text { Church- } \\
\text { Yonge }\end{array}$ & 1800 & $\begin{array}{l}W B T=0.88 \\
W B R=0.79 \\
W B L=0.84\end{array}$ & & & & 50 & & \\
\hline Yonge-Bay & 1800 & $\begin{array}{l}W B T=0.79 \\
W B R=0.69 \\
W B L=0.76\end{array}$ & & & & 40 & & \\
\hline Bay-York & 1800 & $\begin{array}{c}\text { WBT }=0.8 \\
W B R=0.89 \\
W B L=0\end{array}$ & & & $\begin{array}{c}3 m \text { for all } \\
\text { lanes }\end{array}$ & 40 & & \\
\hline $\begin{array}{l}\text { York- } \\
\text { University }\end{array}$ & 1900 & $\begin{array}{l}\text { WBT }=0.76 \\
W B R=0.73 \\
W B L=0.71\end{array}$ & & & & & & \\
\hline $\begin{array}{l}\text { University- } \\
\text { Simcoe }\end{array}$ & 1800 & $\begin{array}{c}\text { WBT }=0.87 \\
W B R=0 \\
W B L=0.93\end{array}$ & & & & & & drop lane \\
\hline $\begin{array}{l}\text { Simcoe- } \\
\text { John }\end{array}$ & 1800 & $\begin{array}{l}W B T=0.83 \\
W B R=0.58 \\
W B L=0.81\end{array}$ & & & & 30 & & \\
\hline $\begin{array}{l}\text { John-Blue } \\
\text { Jays Way }\end{array}$ & 1800 & $\begin{array}{l}W B T=0.61 \\
W B R=0.72 \\
W B L=0.79\end{array}$ & & & & 10 & & $\begin{array}{l}\text { added drop } \\
\text { lane using } \\
\text { bend node } \\
\text { and created } \\
\text { offset of }-2 \\
\text { to account } \\
\text { for left side } \\
\text { drop lane } \\
\text { instead of } \\
\text { right }\end{array}$ \\
\hline
\end{tabular}

Table 5: Calibration Assumption for OFF peak 


\subsubsection{Intersections with On-Street Parking}

During the site visit, on-street parking on the north and south of the corridor was recorded. It should be noted that on-street parking can adversely affect the flow of the traffic in the following ways:

- Capacity loss of the intersection

- Reduction of lane utilization factor

- Increase of delay that can be continued to the other links.

To consider the effect of the above problems in the Synchro model, a checkmark to the box for that approach was applied in the "Adjacent Parking Lane" category from the "Volume Settings". Also, the numbers of parking maneuvers were inserted by estimating the number of cars going in and out of parking stall per hour based on site visits. Figure $\mathbf{4}$ was utilized as an aid for Synchro parking maneuver coding. 


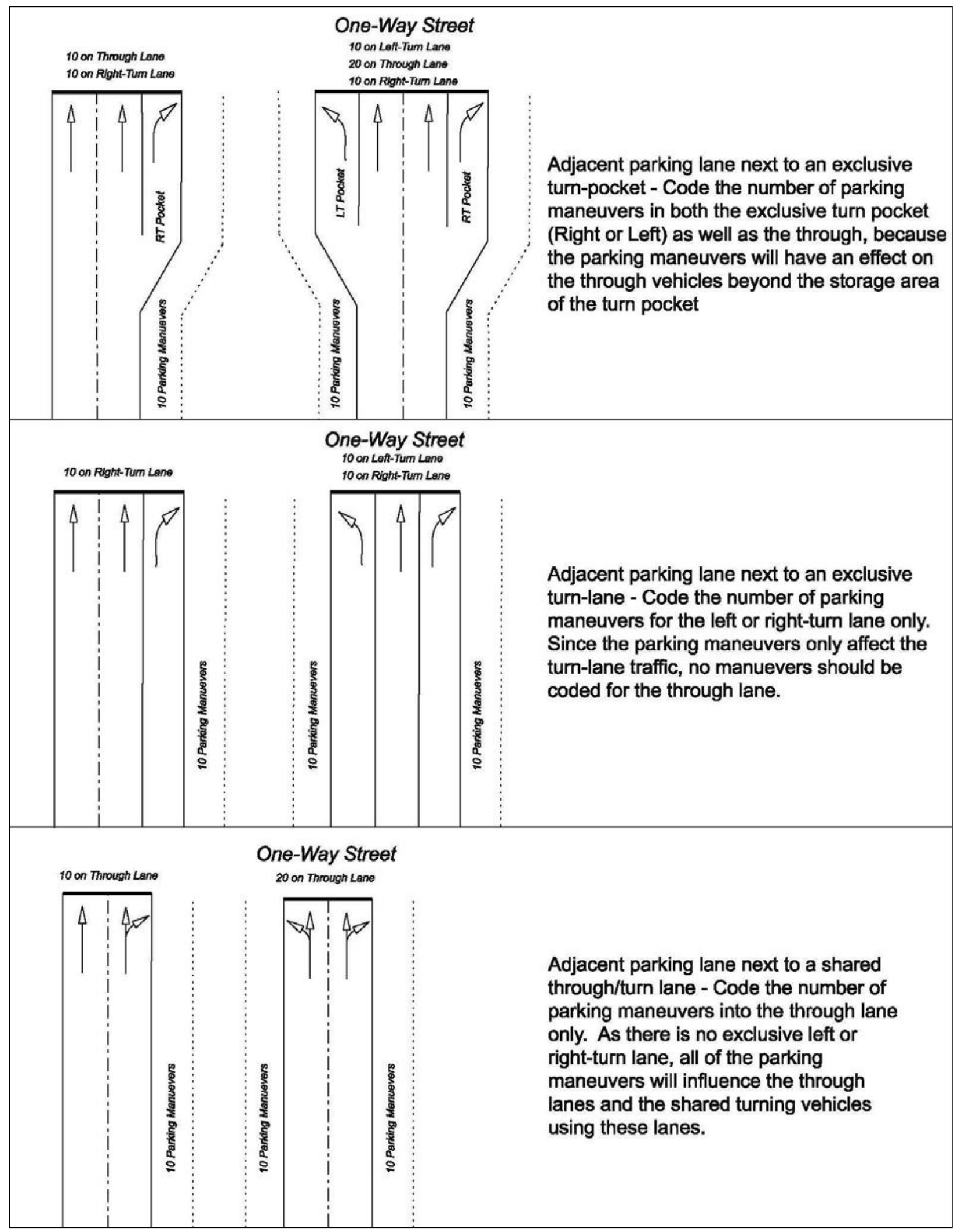

Figure 4-Parking Manoeuvres coding [9] 


\subsection{Validation of the Calibrated Model}

The travel time and delay data from the Travel Run Study were used to validate the calibrated Synchro models. It should be noted that the purpose of calibration is to reflect a known capacity condition, while the purpose of the validation is to verify that models would have similar travel times and delays along the corridor.

The corridor travel time has two components for each segment: travel time (a function of the intersection spacing and the travel speed), and signal delay (the delay experienced due to a red light or queuing).

From Synchro, the arterial level of service report can provide outputs for each segment along the corridor, separated into these two components: segment travel time, and signal delay. These will be compared with the observed data from surveys to determine the validity of the

calibrated model. The calibrated Synchro output is compared with Travel Run Study result and summarized in Table 6. 


\begin{tabular}{|c|c|c|c|c|c|}
\hline \multicolumn{6}{|l|}{ AM } \\
\hline \multicolumn{2}{|l|}{ Segment } & \multirow{2}{*}{$\begin{array}{l}\text { Observed Travel Time } \\
\text { (s) }\end{array}$} & \multirow{2}{*}{$\begin{array}{l}\text { Synchro Calibrated Travel Time } \\
\text { (s) }\end{array}$} & \multirow{2}{*}{$\begin{array}{c}\text { Differenc } \\
\mathbf{e}\end{array}$} & \multirow{2}{*}{$\begin{array}{l}\text { Difference } \\
\text { (\%) }\end{array}$} \\
\hline From & To & & & & \\
\hline Church & Yonge & 85.7 & 59.3 & -26.4 & $-30.8 \%$ \\
\hline Yonge & Bay & 64.3 & 61.6 & -2.7 & $-4.2 \%$ \\
\hline Bay & York & 47.3 & 35.3 & -12.0 & $-25.4 \%$ \\
\hline York & University & 17.8 & 34.4 & +16.6 & $+93.3 \%$ \\
\hline $\begin{array}{l}\text { Universit } \\
\mathrm{y}\end{array}$ & Simcoe & 28.3 & 23.3 & -5.0 & $-17.7 \%$ \\
\hline Simcoe & John & 50.8 & 41.2 & -9.6 & $-18.9 \%$ \\
\hline John & $\begin{array}{l}\text { Blue Jays } \\
\text { Way }\end{array}$ & 30.3 & 48.4 & +18.1 & $+59.7 \%$ \\
\hline \multicolumn{2}{|r|}{ Total: } & 324.5 & 303.5 & -21.0 & $-6.5 \%$ \\
\hline \multicolumn{6}{|l|}{ PM } \\
\hline \multicolumn{2}{|l|}{ Segment } & \multirow[t]{2}{*}{$\begin{array}{l}\text { Observed Travel Time } \\
\text { (s) }\end{array}$} & \multirow[t]{2}{*}{$\begin{array}{l}\text { Synchro Calibrated Travel Time } \\
\text { (s) }\end{array}$} & \multirow[t]{2}{*}{$\begin{array}{l}\text { Differenc } \\
\mathrm{e}\end{array}$} & \multirow[t]{2}{*}{$\begin{array}{l}\text { Difference } \\
\text { (\%) }\end{array}$} \\
\hline From & To & & & & \\
\hline Church & Yonge & 58.5 & 51.5 & -7.0 & $-12.0 \%$ \\
\hline Yonge & Bay & 60.7 & 35.3 & -25.4 & $-41.8 \%$ \\
\hline Bay & York & 54.0 & 41.4 & -12.6 & $-23.3 \%$ \\
\hline York & University & 25.8 & 32.1 & +6.3 & $+24.4 \%$ \\
\hline $\begin{array}{l}\text { Universit } \\
\mathrm{y}\end{array}$ & Simcoe & 35.5 & 30.3 & -5.2 & $-14.6 \%$ \\
\hline Simcoe & John & 47.3 & 47.1 & -0.2 & $-0.4 \%$ \\
\hline John & $\begin{array}{l}\text { Blue Jays } \\
\text { Way } \\
\end{array}$ & 25.8 & 31 & +5.2 & $+20.2 \%$ \\
\hline & Total: & 307.6 & 268.7 & -38.9 & $-12.6 \%$ \\
\hline \multicolumn{6}{|c|}{ OFF PEAK* } \\
\hline \multicolumn{2}{|c|}{ Segment } & \multirow[t]{2}{*}{$\begin{array}{l}\text { Observed Travel Time } \\
\text { (s) }\end{array}$} & \multirow[t]{2}{*}{$\begin{array}{l}\text { Synchro Calibrated Travel Time } \\
\text { (s) }\end{array}$} & \multirow[t]{2}{*}{$\begin{array}{c}\text { Differenc } \\
\mathrm{e}\end{array}$} & \multirow[t]{2}{*}{$\begin{array}{c}\text { Difference } \\
(\%)\end{array}$} \\
\hline From & To & & & & \\
\hline Church & Yonge & 49.6 & 46.3 & -3.3 & $-6.7 \%$ \\
\hline Yonge & Bay & 48.4 & 34.5 & -13.9 & $-28.7 \%$ \\
\hline Bay & York & 62.4 & 32.3 & -30.1 & $-48.2 \%$ \\
\hline York & University & 22.8 & 33.7 & +10.9 & $+47.8 \%$ \\
\hline $\begin{array}{l}\text { Universit } \\
\mathrm{y}\end{array}$ & Simcoe & 33.2 & 27.9 & -5.3 & $-16.0 \%$ \\
\hline Simcoe & John & 54.2 & 33.5 & -20.7 & $-38.2 \%$ \\
\hline John & \begin{tabular}{|l|} 
Blue Jays \\
Way \\
\end{tabular} & 42.6 & 31.0 & -11.6 & $-27.2 \%$ \\
\hline \multicolumn{2}{|c|}{ Total: } & 313.2 & 239.2 & -74 & $-23.6 \%$ \\
\hline
\end{tabular}

Table 6: Travel Time Comparison 
The overall corridor travel times are comparable to the observed corridor travel times and the values are within $6 \%$ to $23 \%$ of target.

\section{Development of Alternative Timing Plans}

\subsection{Methodologies for Signal Optimization}

Signal timing optimization is a process in which delay, the number of stops and travel time will be reduced to improve the traffic flow performances. The following steps were taken for optimization in this study:

Define New Control Areas: The study area was divided into fewer control areas by determining the desirability of coordinating the intersections based on existing traffic operations for each peak period, current cycle length, minimum cycle length, through volumes on Wellington Street, road classification, intersection space distance, intersection control type and coordinatability provide by Synchro. The control areas for Yonge and University Streets were locked since they are part of the north-south coordination. The proposed control areas are shown in Table 7.

\begin{tabular}{|c|c|c|c|c|c|c|c|c|c|c|c|}
\hline \multirow[t]{2}{*}{ PX\# } & \multirow{2}{*}{$\begin{array}{l}\text { INTERSECTION } \\
\text { NAME }\end{array}$} & \multirow{2}{*}{$\begin{array}{l}\text { Min. } \\
\text { Cycle } \\
\text { Length }\end{array}$} & \multicolumn{3}{|c|}{ Min CL } & \multicolumn{4}{|c|}{ Current } & \multicolumn{2}{|c|}{ Proposed } \\
\hline & & & AM & OFF & PM & AM & OFF & PM & AM & OFF & PM \\
\hline 15 & Church St & 50 & 88 & 88 & 88 & 88 & 90 & 90 & 90 & 90 & 90 \\
\hline 30 & Yonge St & 50 & 64 & 64 & 64 & 64 & 80 & 75 & 80 & 80 & 75 \\
\hline 60 & Bay St & 50 & 64 & 64 & 53 & 53 & 70 & 60 & 70 & 80 & 75 \\
\hline 71 & York St & 50 & 56 & 67 & 67 & 67 & 70 & 60 & 70 & 80 & 75 \\
\hline 76 & University Ave & 50 & 75 & 75 & 64 & 64 & 110 & 100 & 110 & 110 & 100 \\
\hline 264 & Simcoe St & 50 & 53 & 53 & 53 & 53 & 70 & 70 & 70 & 80 & 80 \\
\hline 1489 & John St & 50 & 54 & 54 & 54 & 54 & 70 & 70 & 70 & 80 & 80 \\
\hline 1682 & Blue Jays Way & 50 & 70 & 70 & 70 & 70 & 70 & 70 & 70 & 80 & 80 \\
\hline
\end{tabular}

Table 7-Proposed Control Area

\subsubsection{Optimization of Splits}

For the split optimization, each control area was optimized separately according to its new proposed cycle length. In this optimization process, the objective function is to minimize the splits. Splits are optimized by percentile, with Synchro attempting to provide enough green time 
to serve $90 \%$ of the flow from a lane group. All phases are assigned to a split greater or equal to their Minimum Split. If the minimum split is greater than the cycle length, then the optimization repeats the process and attempts $70^{\text {th }}$ percentile and then $50^{\text {th }}$ percentile. Parameters required for this optimization are volume, lanes, left turn type, fixed timing and cycle length.

The constrains function is the cycle length, since Toronto District believes that not more than 80 second cycle length should be considered for downtown area.

Within a control area, different split phasing may have been assigned for each of the intersections during the AM Peak, daytime OFF Peak and PM Peak.

The following manual adjustments on splits were applied on the optimized model:

- Ensured that the new timing of each advanced left turn phase would not be greater than 20 seconds; and

- Ensured that the new timing of each critical movement would not have an enormous change, especially for major-major intersections.

\subsubsection{Optimization of Offsets}

With the new cycle lengths and splits, each control area was optimized as a separate system in offset optimization, and per City's guidelines [8].

The objective in offset optimization is to minimize delay for each zone so it works well with its adjacent signals. Parameters required for offset optimization are distance between intersections, speed limit, volume, lanes, fixed timing and cycle length. City of Toronto limits the offset to be referenced to "beginning of green" and NEMA phases " $2+6$ ".

\subsection{Review Left / Right Turn Movements}

After the optimization of cycle lengths, splits, and offsets, the new MOEs were reviewed in Synchro. Among the three optimized models, the following left turn phases were proposed to be changed from permissive to protected / permissive operation in Table 8.

Table 8-Proposed Left-Turn Phase

\begin{tabular}{|l|l|l|l|}
\hline Intersections & $\begin{array}{l}\text { New Advanced } \\
\text { Left/Right-Turn }\end{array}$ & Timing Plan & Status \\
\hline Simcoe at Wellington & Northbound Left-Turn & $\begin{array}{l}\text { AM \& PM } \\
\text { Peak }\end{array}$ & Implementation in 2015 \\
\hline Simcoe at Wellington & Eastbound Right -Turn & $\begin{array}{l}\text { AM \& PM } \\
\text { Peak }\end{array}$ & Implementation in 2015 \\
\hline
\end{tabular}


Note that the NBLA/EBRA will only come up if the NB demand exceeds 2 cars. Additional hardware (e.g., left-turn signal heads and detector setback loops, etc.) and budget are required for implementation. The proposed Timing plans are provided in Appendix G. 


\section{6. $\quad$ Evaluation of Proposed Signal Timings}

\subsection{Intersection and Movement Traffic Operations}

The main measures of effectiveness ("MOE") are the travel time comparison between the calibrated existing conditions and the alternative conditions for AM, OFF and PM peak periods. Other MOE such as delay, the number of stops, capacity utilization (V/C ratio), average speed, fuel consumption, and emissions are also considered for the evaluation of the proposed alternatives.

\subsubsection{Evaluation of AM Peak Period}

Synchro optimized travel times are summarized in Table 9.

Table 9-AM Optimized Travel Time

\begin{tabular}{|c|c|c|c|c|c|}
\hline \multicolumn{2}{|c|}{ Segment } & \multirow{2}{*}{$\begin{array}{c}\text { Synchro } \\
\text { Calibrated } \\
\text { Travel Time }\end{array}$} & \multirow{2}{*}{$\begin{array}{c}\text { Synchro } \\
\text { Optimized } \\
\text { Travel Time } \\
\end{array}$} & \multirow[t]{2}{*}{ difference (Opt. - Cal.) } & \multirow{2}{*}{ Difference (\%) } \\
\hline From & To & & & & \\
\hline church & Yonge & 59.3 & 58.5 & -0.8 & $-1.3 \%$ \\
\hline Yonge & Bay & 61.6 & 33.9 & -27.7 & $-45.0 \%$ \\
\hline Bay & York & 35.3 & 30.4 & -4.9 & $-13.9 \%$ \\
\hline York & University & 34.4 & 34.3 & -0.1 & $-0.3 \%$ \\
\hline University & Simcoe & 23.3 & 28.7 & +5.4 & $+23.2 \%$ \\
\hline Simcoe & John & 41.2 & 35.1 & -6.1 & $-14.8 \%$ \\
\hline \multirow[t]{2}{*}{ John } & Blue Jays Way & 48.4 & 19.1 & -29.3 & $-60.5 \%$ \\
\hline & & 303.5 & 240.0 & -63.5 & \\
\hline & & & $\begin{array}{c}\text { Effective } \\
\text { Difference: }\end{array}$ & -68.0 & \\
\hline
\end{tabular}

Overall, the proposed coordination plan reduces westbound travel times along the entire corridor by 68.0 (-26.4\%) second. One corridor control area-between Yonge Street and York Streetexperienced a significant decrease in travel time. It should be noted that these intersections are closely spaced, and the decrease in travel time and coordinatability is very important. Also, another significant decrease in travel time could be observed on the stretch between Simcoe Street to Blue Jays Way Street, where the travel time in this control area has been improved by approximately 35 seconds. 


\subsubsection{Evaluation of PM Peak Period Alternatives}

The impacts to westbound travel times corresponding with the revised timing plans for the PM peak periods are presented in Table $\mathbf{1 0 .}$

Table 10-PM Optimized Travel Time

\begin{tabular}{|c|c|c|c|c|c|}
\hline \multicolumn{2}{|c|}{ Segment } & \multirow{2}{*}{$\begin{array}{c}\text { Synchro } \\
\text { Calibrated } \\
\text { Travel Time }\end{array}$} & \multirow{2}{*}{$\begin{array}{c}\text { Synchro } \\
\text { Optimized } \\
\text { Travel Time }\end{array}$} & \multirow{2}{*}{$\begin{array}{l}\text { Difference (Opt. - } \\
\text { Cal.) }\end{array}$} & \multirow{2}{*}{$\begin{array}{c}\text { Difference } \\
(\%)\end{array}$} \\
\hline From & To & & & & \\
\hline church & Yonge & 51.5 & 51.6 & +0.1 & $+0.2 \%$ \\
\hline Yonge & Bay & 35.3 & 33.2 & -2.1 & $-5.9 \%$ \\
\hline Bay & York & 41.4 & 36.9 & -4.5 & $-10.9 \%$ \\
\hline York & University & 32.1 & 32.6 & +0.5 & $+1.6 \%$ \\
\hline University & Simcoe & 30.3 & 30.5 & +0.2 & $+0.7 \%$ \\
\hline Simcoe & John & 47.1 & 41.4 & -5.7 & $-12.1 \%$ \\
\hline \multirow[t]{2}{*}{ John } & $\begin{array}{c}\text { Blue Jays } \\
\text { Way }\end{array}$ & 31 & 24.5 & -6.5 & $-21.0 \%$ \\
\hline & & 268.7 & 250.7 & -18.0 & \\
\hline & & & $\begin{array}{c}\text { Effective } \\
\text { Difference: }\end{array}$ & -18.8 & \\
\hline
\end{tabular}

Overall the proposed coordination plan reduces westbound travel times across the entire corridor by $18.8(-7.2 \%)$. The most notable decreased travel time is between Simcoe Street and Blue Jays Way Street. A similar improvement is observed for another segment of the corridor between Yonge Street to York Street, where the cycle length in this control area has been increased by 10 second.

\subsubsection{Evaluation of OFF Peak Period Alternatives}

The impacts to westbound travel times corresponding with the revised timing plans for the OFF peak period are presented in Table 11. 
Table 11-OFF Peak Optimized Travel Time

\begin{tabular}{|c|c|c|c|c|c|}
\hline \multicolumn{2}{|c|}{ Segment } & \multirow{2}{*}{$\begin{array}{c}\text { Synchro } \\
\text { Calibrated } \\
\text { Travel Time }\end{array}$} & \multirow{2}{*}{$\begin{array}{l}\text { Synchro Optimized } \\
\text { Travel Time }\end{array}$} & \multirow{2}{*}{$\begin{array}{c}\text { Difference (Opt. - } \\
\text { Cal.) }\end{array}$} & \multirow{2}{*}{$\begin{array}{c}\text { Difference } \\
(\%)\end{array}$} \\
\hline From & To & & & & \\
\hline church & Yonge & 46.3 & 46.3 & 0.0 & $0.0 \%$ \\
\hline Yonge & Bay & 34.5 & 33.1 & -1.4 & $-4.1 \%$ \\
\hline Bay & York & 32.3 & 31.2 & -1.1 & $-3.4 \%$ \\
\hline York & University & 33.7 & 34.2 & +0.5 & $+1.5 \%$ \\
\hline University & Simcoe & 27.9 & 27.9 & 0.0 & $0.0 \%$ \\
\hline Simcoe & John & 33.5 & 36.5 & +3.0 & $+9.0 \%$ \\
\hline John & $\begin{array}{c}\text { Blue Jays } \\
\text { Way }\end{array}$ & 31.0 & 21.1 & -9.9 & $-31.9 \%$ \\
\hline From & To & 46.3 & 252.3 & -5.1 & \\
\hline & & & Effective Difference: & -9.4 & \\
\hline
\end{tabular}

Overall the proposed coordination plan reduces northbound and southbound travel times across the entire corridor by $9.4(-3.8 \%)$. Some corridor segments experienced increases in travel time, the most notable of which is the westbound travel time between Simcoe Street and John Street. Otherwise, travel times for most control areas have been improved.

\subsection{Time-Space Diagram}

After implementation of the new timing plans, the offset developed from Synchro model should be verified with City's TransSuite TSD software. This software allows the user to create timespace diagrams for user-defined group signals. To generate a TSD using this software the signal spacing and posted speed limited should be inserted as an input. After creating the TSD it allows the user to monitor the start and end of the main street green times and green bands that would have been provided for all coordinated signals in a control area. Screenshots of the TSD are provided in Figure 5, Figure 6 and Figure 7. 




Figure 5: TransSuite TSD AM Peak 


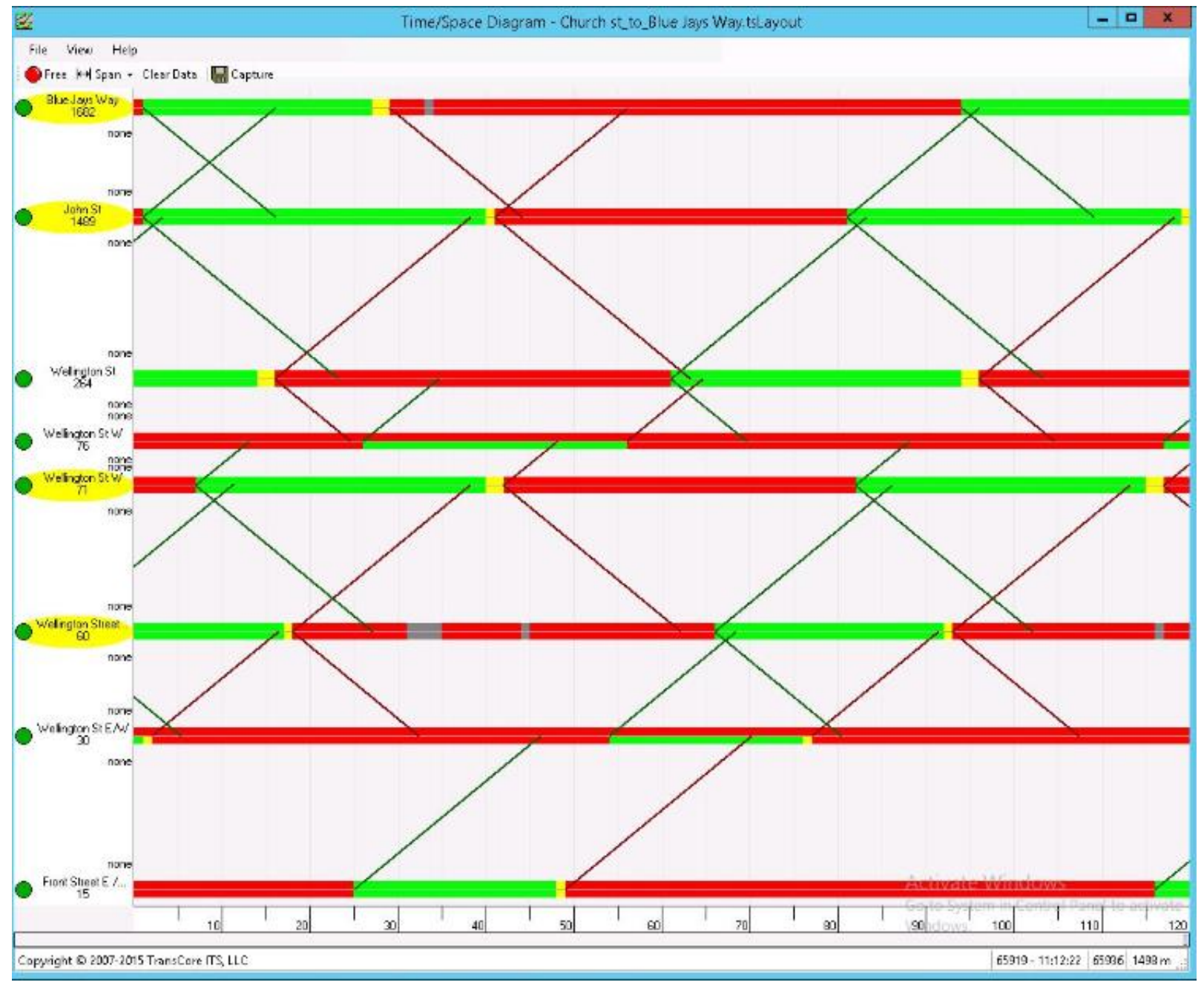

Figure 6: TransSuite TSD OFF Peak 


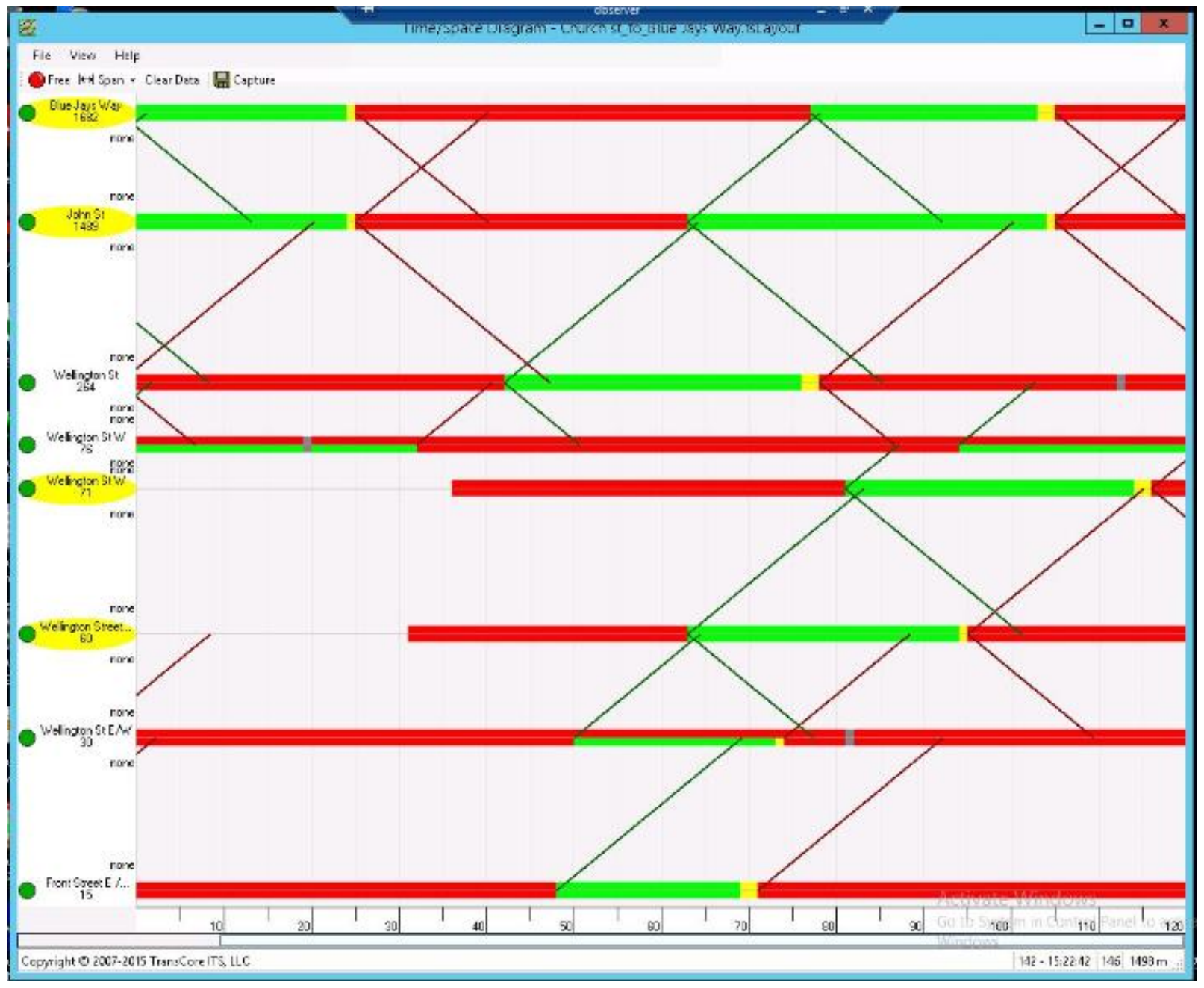

Figure 7: TransSuite TSD PM 


\subsection{MOE and Operation Summary}

All intersections and movements are evaluated using Synchro. The detailed MOEs per movement are recorded in Appendix F for the daytime OFF Peak, AM Peak, and PM Peak, respectively and the overall intersection $\mathrm{MOE}$ is summarized below.

\section{Level of Service (LOS)}

Table 12 summarizes the changes to the intersection LOS after optimization (with those intersections that improved LOS highlighted in green).

Overall, the signalized intersections maintain the LOS for all peak periods, except for Simcoe Street where the overall LOS after optimization has declined to C. For Simcoe Street, it should be noted that before signal optimization the signal plan was with respect to the northbound through movements only and no left turn signal existed. However, after installation of a new northbound left turn phase and removing the northbound through movement on Simcoe Street, the southbound movements, experienced a longer delay. It should be noted that the goal of coordination is to favour westbound movements over all other movements. Table 12 summarizes the overall intersection LOS.

\begin{tabular}{|c|l|c|c|c|c|c|c|}
\hline \multirow{2}{*}{ PX\# } & \multirow{2}{*}{ Intersection Name } & \multicolumn{3}{|c|}{ Before } & \multicolumn{3}{c|}{ After } \\
\cline { 3 - 7 } & & AM & PM & OFF & AM & PM & OFF \\
\hline 15 & $\begin{array}{l}\text { Church \& Wellington } \\
\text { St }\end{array}$ & E & F & C & E & F & C \\
\hline 30 & $\begin{array}{l}\text { Yonge \& Wellington } \\
\text { St }\end{array}$ & C & C & B & C & C & B \\
\hline 60 & Bay \& Wellington St & C & B & B & C & B & B \\
\hline 71 & York \& Wellington St & B & B & B & B & B & B \\
\hline 76 & $\begin{array}{l}\text { University Ave \& } \\
\text { Wellington St }\end{array}$ & C & C & B & C & C & B \\
\hline 264 & $\begin{array}{l}\text { Simcoe \& Wellington } \\
\text { St }\end{array}$ & E & F & B & E & F & C \\
\hline 1489 & John \& Wellington St & B & C & B & B & C & B \\
\hline 1682 & $\begin{array}{l}\text { Blue Jays Way \& } \\
\text { Wellington St }\end{array}$ & C & C & C & C & C & C \\
\hline
\end{tabular}

Table 12-Intersection LOS

An example of detailed movement performance is illustrated in Table 13. For all other intersections refer to Appendix F. 


\begin{tabular}{|l|l|l|l|l|l|l|l|l|}
\hline \multirow{2}{*}{$\begin{array}{l}\text { Movement of } \\
\text { Interest }\end{array}$} & \multicolumn{4}{|l|}{ Am-Peak Baseline } & \multicolumn{2}{l|}{ Am-Peak Optimized1 } & \multicolumn{2}{l|}{ Difference } \\
\cline { 2 - 9 } & $\begin{array}{l}\text { v/c } \\
\text { Ratio }\end{array}$ & $\begin{array}{l}\text { Total } \\
\text { Delay }\end{array}$ & (LOS) & $\begin{array}{l}\text { v/c } \\
\text { Ratio }\end{array}$ & $\begin{array}{l}\text { Total } \\
\text { Delay }\end{array}$ & (LOS) & v/c Ratio & $\begin{array}{l}\text { Total } \\
\text { Delay }\end{array}$ \\
\hline WBT & 0.4 & 16.8 & B & 0.48 & 10.7 & B & 0.08 & -6.1 \\
\hline NBT & 0.97 & 42 & D & 0.83 & 20.2 & C & -0.14 & -21.8 \\
\hline SBT & 0.82 & 35.8 & D & 0.58 & 20.2 & C & -0.24 & -15.6 \\
\hline
\end{tabular}

Table 13: Individual Movement Performance

\section{Maximum V/C Ratio}

Table 14 summarizes the 'before' and 'after' overall v/c ratios for each of the intersections for all three peak periods. Note that in the "Difference" column, a negative value indicates a better v/c ratio. [10]

Table 14: Summary of Maximum V/C Ratios

\begin{tabular}{|c|l|c|c|c|c|c|c|c|c|c|}
\hline \multirow{2}{*}{ PX\# } & \multirow{2}{*}{ INTERSECTION NAME } & \multicolumn{4}{|c|}{ Maximum V/C Ratio } \\
\cline { 3 - 11 } & & \multicolumn{3}{|c|}{ Before } & \multicolumn{3}{c|}{ After } & \multicolumn{3}{c|}{ Difference } \\
\cline { 3 - 10 } & & OFF & AM & PM & OFF & AM & PM & OFF & AM & PM \\
\hline 15 & Church \& Wellington St & 0.64 & 0.93 & 1.28 & $\mathbf{0 . 6 4}$ & $\mathbf{0 . 9 3}$ & $\mathbf{1 . 2 8}$ & 0.00 & 0.00 & 0.00 \\
\hline 30 & Yonge \& Wellington St & 0.55 & 0.76 & 0.55 & $\mathbf{0 . 5 5}$ & $\mathbf{0 . 7 6}$ & $\mathbf{0 . 5 5}$ & 0.00 & 0 & 0.00 \\
\hline 60 & Bay \& Wellington St & 0.61 & 0.83 & 0.66 & $\mathbf{0 . 5 8}$ & $\mathbf{0 . 8 3}$ & $\mathbf{0 . 6 4}$ & -0.03 & 0 & -0.02 \\
\hline 71 & York \& Wellington St & 0.50 & 0.69 & 0.66 & $\mathbf{0 . 4 8}$ & $\mathbf{0 . 6 9}$ & $\mathbf{0 . 6 4}$ & -0.02 & 0 & -0.02 \\
\hline 76 & University Ave. \& Wellington St & 0.54 & 0.63 & 0.65 & $\mathbf{0 . 5 4}$ & $\mathbf{0 . 6 3}$ & $\mathbf{0 . 6 5}$ & 0.00 & 0 & 0.00 \\
\hline 264 & Simcoe \& Wellington St & 0.45 & 0.65 & 0.90 & $\mathbf{0 . 5 3}$ & $\mathbf{0 . 6 5}$ & $\mathbf{1 . 0 2}$ & 0.08 & 0 & 0.12 \\
\hline 1489 & John \& Wellington St & 0.42 & 0.65 & 0.73 & $\mathbf{0 . 4 1}$ & $\mathbf{0 . 6 5}$ & $\mathbf{0 . 7 2}$ & -0.01 & 0 & -0.01 \\
\hline 1682 & Blue Jays Way \& Wellington St & 0.63 & 0.68 & 0.85 & $\mathbf{0 . 6 3}$ & $\mathbf{0 . 6 8}$ & $\mathbf{0 . 8 4}$ & 0.00 & 0 & -0.01 \\
\hline
\end{tabular}

\section{Economic and Environmental Benefits}

The economic and environmental impacts of the project are discussed in this section. The environmental and economic impacts of the signal timing improvements have also been measured to produce a summary of tangible improvements gained from this study. To analyze the economic impacts for the corridor, a cost-benefit analysis was undertaken [11]. The project costs and benefits were based on the following information:

- Model Output

- Delay 
- Fuel Consumption

- $\quad$ Project Cost

The project environmental impacts were based on the following model outputs:

- Carbon Monoxide produced

- Nitrogen Oxides produced

\subsection{Economic Benefits}

To determine whether traffic signal coordination was successful in terms of cost-effectiveness, a benefit and cost was analysis was performed. The benefits of the project were measured in terms of savings of the consumption of gas, the value of stops, and the economic value of delay. The assumptions and references for the benefit-cost ratio are summarized below:

- The daily benefit should be based on 2hrs of AM/PM and 4hrs of OFF peak

- The annual benefits should be based on 250 weeks per year [4].

- The savings in \$ for travel time should be based on travel time value at US \$15.86 per hour [4].

- The savings in $\$$ for number of stops should be based on the value of US at $\$ 0.014$ per stop [4].

- The savings in $\$$ for fuel consumption should be based on Toronto's average fuel cost throughout the year at CAN per liter for 2015 [12].

- The estimated City's cost to conduct signal coordination $\$ 2450$ since the was conducted internally and includes costs such as Project information collection, Site investigations, traffic data counts, Synchro model reviews and uploading the new timing plans into the controller

- The savings in $\$$ for Carbon Monoxide should be based on the value of US at $\$ 7.011$ per Kilogram [4].

- The savings in $\$$ for Nitrogen Oxide should be based on the value of US at $\$ 14.192$ per Kilogram [4]. 
- The currency conversion rate should be based on \$1.27 from CAN\$ to US\$

- Number of signals within the signal coordination study

Benefits for this study are estimated for a period of one year and converted to present value [10] for a life cycle of 3 years [11] and discount rate of 4\% [13]. The benefit and cost ratio is perfumed using the following equation:

$\mathrm{R}=$ Benefit-Cost Ratio, $\mathrm{B}=$ Total Value of the Benefits, $\mathrm{C}=$ Total Value of the Costs

$$
R=\frac{B}{C}
$$

The benefit, cost, and benefit-cost ratio are summarized in Table 15.

\begin{tabular}{|c|c|c|c|c|c|c|c|}
\hline $\begin{array}{l}\text { Measure of } \\
\text { Effectiveness }\end{array}$ & $\begin{array}{l}\text { Delays } \\
\text { (hrs) }\end{array}$ & Stops & $\begin{array}{l}\text { Speed } \\
(\mathrm{Km} / \mathrm{hr})\end{array}$ & $\begin{array}{l}\text { Travel } \\
\text { Time } \\
\text { (hr) }\end{array}$ & $\begin{array}{l}\text { Fuel } \\
\text { Consumed } \\
\text { (I) }\end{array}$ & $\begin{array}{l}\text { CO } \\
\text { Emissions } \\
(\mathrm{kg})\end{array}$ & $\begin{array}{l}\text { NOx } \\
\text { Emissions } \\
\text { (kg) }\end{array}$ \\
\hline Before & 271,500 & $20,038,000$ & 15 & 378,000 & $1,704,500$ & 31,550 & 6,095 \\
\hline After & 270,500 & $19,028,000$ & 16.25 & 374,000 & $1,666,500$ & 30,995 & 5,985 \\
\hline Improvement & $\$ 1000$ & $\$ 1,010000$ & $\$-1.25$ & $\$ 4,000$ & $\$ 38,000$ & $\$ 555$ & $\$ 110$ \\
\hline $\begin{array}{l}\% \\
\text { Improvement }\end{array}$ & $0 \%$ & $5 \%$ & $-8 \%$ & $1 \%$ & $2 \%$ & $2 \%$ & $2 \%$ \\
\hline Annual Benefit & $\$ 22,559$ & $\$ 20,113$ & - & - & $\$ 41,420$ & $\$ 5,535$ & $\$ 2,221$ \\
\hline $\begin{array}{l}\text { Present Value } \\
\text { of Discounted } \\
\text { Future Benefit }\end{array}$ & $\$ 62,604$ & $\$ 55,815$ & & & $\$ 114,944$ & $\$ 15,359$ & $\$ 6,162$ \\
\hline Total Benefits & \multicolumn{7}{|c|}{$\$ 254,884$} \\
\hline Cost & \multicolumn{7}{|c|}{$\$ 19,600$} \\
\hline $\begin{array}{l}\text { Benefit-Cost } \\
\text { Ratio }\end{array}$ & \multicolumn{7}{|c|}{$13: 1$} \\
\hline
\end{tabular}

Table 15: Benefit-Cost Analysis

The signal coordination benefit-cost ratio is $13: 1$, meaning that benefit of the investment including travel time savings, stops and fuel emissions exceeds the life cycle cost by a factor of thirteen meaning the project is worthwhile. 


\section{Conclusions and Recommendations}

This study was completed to improve the coordination of traffic signals along Wellington Street West from Church Street to Blue Jays Way Street. The analysis methodologies, findings, and recommendations from the study are documented in this report. In summary, the project included 8 signalized intersections. The study included a review of the signal timings and coordination for AM, OFF and PM peak periods. The purpose of this project was to optimize signals through modification of signal timing plans while maintaining reasonably minimal impacts to the side street levels of service and delays. Inherently, the improvement of coordination yields reduced travel times, delays, a number of stops, and fuel consumption - producing a better driving experience for all motorists.

The required field data for the analyses were collected at the beginning of the study, including turning movement counts (TMC), existing and historical timing plan, intersection drawings, and peak hour factor. The field visit was conducted to confirm the intersection and lane configuration or to observe any signal deficiencies. Travel run and delay study was conducted using GPS equipment and later transferred into the computer using PC-Travel software. The purpose of before period travel run and delay study was to assist with the calibration of the Synchro model before optimization. The model calibration process was educational and enforced the fundamental concepts and principle of traffic engineering. Therefore, the baseline Synchro models were developed and then calibrated for the AM, PM, and OFF peak periods for use in future analysis. The models were calibrated to the observed travel times throughout the corridor, and calibration was achieved by adjusting the Synchro parameters

based on field observations. For each of the three time periods, calibration was achieved such that the modeled travel times were within $6 \%$ to $20 \%$ of the observed travel times over the entire corridor. The associated microsimulation software, Simtraffic and TransSuite also demonstrated the effectiveness when developing and visualizing offset and split solutions and the corresponding progression through 'green band'. 
The following factors had a negative impact on signal coordination and the smooth flow of traffic:

- On Street Construction,

- Illegal On-Street Parking,

- Reduces lanes -available to through traffic from three to two lanes in some areas.

- Parking Regulations

- Volume exceeding the capacity

This project proved that with a good understanding of signal timing concept, the user could leverage the strength of signal timing model and engineering judgment.

Finally, the benefits derived from this project proved that signal timing should not be compromised in the field and an effort like this to perform city-wide signal timing optimization is well worth the money. The benefits outweighed the cost of the entire project.

\section{$\underline{\text { Recommendation }}$}

Trafficware's Synchro model is a well used and accepted traffic optimization and moddeling in North America, which has also the ability of calculation emission as seen in this report. Although Synchro is a traffic model but it only provides relatively crude traffic emission estimates.

In recognition of the need for more detailed emissions analyses for project evaluation and other micro-scale applications, the EPA is currently in the testing stage of the second implementation of a comprehensive mobile emissions model, MOVES-HVI (Motor Vehicle Emissions Simulator). The EPA reports that MOVES will incorporate second-by-second speed traces and vehicle specific power (which accounts for acceleration, speed, grade and road load) to allow project level dis-aggregate analysis of emissions. Both Synchro (the traffic model) and MOVES (the emissions model) are designed and function better with real assessments than detailed line assessments [14].

Assessing the emissions benefits of traffic signal coordination would be much better served by using MOVES C and MicroFac or similar model. With a MicroFac model one can address the specifics of the system, the fleet mix and the specifics of the arterial corridors being considered, to obtain reliable estimates of the probable fuel savings and emission reductions and be best assured that they are valid and reasonable [15]. 
While the Synchro model gives an indication of the energy and environmental benefits, MOVES would allow for a more detailed assessment, and the MicroFac model would allow for an even higher confidence in result and conclusion validity. 


\section{APPENDIX A}

TMC and PHF Data 


\section{City of Toronto - Traffic Safety Unit}

\section{Peak Hour Factor Calculations Report}

$\begin{array}{lll}\text { Survey Date: } & \text { Apr-23-2009 } & \text { (Thursday) } \\ \text { Survey Type: } & \text { Routine Hours } & \end{array}$

\section{CHURCH ST AT FRONT ST \& WELLINGTON ST (PX 15)}

Movement Peak Hour Factors

\begin{tabular}{crrrr} 
& NB_Thru & NB_Right & NB_Left & EB_Thru \\
AM & 0.783 & 0.554 & 0.625 & 0.835 \\
PM & 0.896 & 0.825 & 0.667 & 0.764 \\
Peak Hour Factors & & & & \\
\cline { 2 - 3 } & NB & EB & SB & WB \\
AM & 0.780 & 0.781 & 0.878 & 0.802 \\
PM & 0.885 & 0.774 & 0.924 & 0.848
\end{tabular}

Intersection Peak Hour Factors

AM

0.946

PM

0.853 


\section{City of Toronto - Traffic Safety Unit}

\section{Peak Hour Factor Calculations Report}

$\begin{array}{lll}\text { Survey Date: } & \text { May-06-2014 } & \text { (Tuesday) } \\ \text { Survey Type: } & \text { Routine Hours } & \end{array}$

WELLINGTON ST AT YONGE ST (PX 30)

Movement Peak Hour Factors

NB_Thru NB_Right

AM

0.885

0.915

PM
NB_Left

0.921

0.926
EB_Thru

EB_Right
EB_Left

\section{SB_Thru}

$$
0.983
$$

B_Right

0.872

0.938

0.875
SB_Left
WB_Thru

0.933

0.874
WB_Right WB_Left

0.538

0.870

$\underline{\text { Peak Hour Factors }}$

$\begin{array}{rrrrr} & \text { NB } & \text { EB } & \text { SB } & \text { WB } \\ \text { AM } & 0.900 & & 0.934 & 0.926 \\ \text { PM } & 0.931 & & 0.920 & 0.886\end{array}$

Intersection Peak Hour Factors

AM

0.953

PM

0.923 


\section{City of Toronto - Traffic Safety Unit}

\section{Peak Hour Factor Calculations Report}

$\begin{array}{lll}\text { Survey Date: } & \text { Aug-12-2009 } & \text { (Wednesday) } \\ \text { Survey Type: } & \text { Routine Hours } & \end{array}$

BAY ST AT WELLINGTON ST (PX 60)

Movement Peak Hour Factors

\begin{tabular}{|c|c|c|c|c|c|c|c|c|c|c|c|c|}
\hline & NB_Thru & NB_Right & NB_Left & EB_Thru & EB_Right & EB_Left & SB_Thru & SB_Right & SB_Left & WB_Thru & WB_Right & WB_Left \\
\hline AM & 0.959 & & 0.891 & & & & 0.901 & 0.980 & & 0.970 & 0.750 & 0.786 \\
\hline PM & 0.976 & & 0.569 & & & & 0.943 & 0.903 & & 0.909 & 0.617 & 0.777 \\
\hline \multicolumn{13}{|c|}{ Peak Hour Factors } \\
\hline & NB & EB & SB & WB & & & & & & & & \\
\hline AM & 0.952 & & 0.922 & 0.972 & & & & & & & & \\
\hline PM & 0.953 & & 0.939 & 0.916 & & & & & & & & \\
\hline \multicolumn{13}{|c|}{ Intersection Peak Hour Factors } \\
\hline AM & & & & 0.981 & & & & & & & & \\
\hline PM & & & & 0.988 & & & & & & & & \\
\hline
\end{tabular}




\section{City of Toronto - Traffic Safety Unit}

\section{Peak Hour Factor Calculations Report}

$\begin{array}{lll}\text { Survey Date: } & \text { Aug-07-2012 } & \text { (Tuesday) } \\ \text { Survey Type: } & \text { Routine Hours } & \end{array}$

\section{WELLINGTON ST AT YORK ST (PX 71)}

Movement Peak Hour Factors

NB_Thru NB_Right

NB_Left

EB_Thru

EB_Right

EB_Left

SB_Thru SB_Right

SB_Left

WB_Thru

WB_Right WB_Left

AM

0.883

0.824

0.750

PM

0.832

0.880

0.855

$0.953 \quad 0.910$

Peak Hour Factors

$\begin{array}{llll}N B & E B & S B & W B\end{array}$

$0.937 \quad 0.926$

AM $\quad 0.937$

0.962

Intersection Peak Hour Factors

AM

0.974

PM

0.960 


\section{City of Toronto - Traffic Safety Unit}

\section{Peak Hour Factor Calculations Report}

$\begin{array}{lll}\text { Survey Date: } & \text { May-05-2011 } & \text { (Thursday) } \\ \text { Survey Type: } & \text { Routine Hours }\end{array}$

UNIVERSITY AVE AT WELLINGTON ST (PX 76)

Movement Peak Hour Factors

\begin{tabular}{|c|c|c|c|c|c|c|c|c|c|c|c|}
\hline NB_Thru & NB_Right & NB_Left & EB_Thru & EB_Right & EB_Left & SB_Thru & SB_Right & SB_Left & WB_Thru & WB_Right & WB_Left \\
\hline 0.904 & & 0.871 & & & & 0.859 & 0.781 & & 0.892 & 0.860 & 0.900 \\
\hline 0.936 & & 0.483 & & & & 0.723 & 0.800 & & 0.802 & 0.802 & 0.914 \\
\hline
\end{tabular}

$\underline{\text { Peak Hour Factors }}$

\begin{tabular}{|c|c|c|c|c|}
\hline & NB & EB & SB & WB \\
\hline AM & 0.900 & & 0.877 & 0.925 \\
\hline PM & 0.912 & & 0.731 & 0.841 \\
\hline
\end{tabular}

Intersection Peak Hour Factors

AM

0.929

PM

0.899 


\section{City of Toronto - Traffic Safety Unit}

\section{Peak Hour Factor Calculations Report}

$\begin{array}{lll}\text { Survey Date: } & \text { Nov-26-2009 } & \text { (Thursday) } \\ \text { Survey Type: } & \text { Routine Hours } & \end{array}$

SIMCOE ST AT WELLINGTON ST (PX 264)

Movement Peak Hour Factors

NB_Thru NB_Right NB_Left

EB_Thru

EB_Right

EB_Left SB_Thru SB_Right

SB_Left

WB_Thru

WB_Right WB_Left

AM

0.617

$0.810 \quad 0.840$

0.853

0.886

0.915

0.916

0.717

0.914

0.925

$\underline{\text { Peak Hour Factors }}$

$\begin{array}{rrrrr} & \text { NB } & \text { EB } & \text { SB } & \text { WB } \\ \text { AM } & & 0.617 & 0.931 & 0.898 \\ \text { PM } & & 0.915 & 0.883 & 0.926\end{array}$

Intersection Peak Hour Factors

AM

0.946

PM

0.950 


\section{City of Toronto - Traffic Safety Unit}

\section{Peak Hour Factor Calculations Report}

$\begin{array}{lll}\text { Survey Date: } & \text { Apr-23-2009 } & \text { (Thursday) } \\ \text { Survey Type: } & \text { Routine Hours } & \end{array}$

JOHN ST AT WELLINGTON ST (PX 1489)

Movement Peak Hour Factors

$\begin{array}{lrrr} & \text { NB_Thru } & \text { NB_Right } & \text { NB_Left } \\ \text { AM } & 0.899 & 0.767 & 0.625 \\ \text { PM } & 0.833 & 0.600 & 0.750\end{array}$

EB_Thru EB_Right

EB_Left
SB_Thru SB_Right

0.884

0.929
0.900

SB_Left

0.793

0.958
WB_Thru

0.841

0.830
WB_Right WB_Left

$0.869 \quad 0.708$

$0.913 \quad 0.710$

Peak Hour Factors

$\begin{array}{rrrrr} & \text { NB } & \text { EB } & \text { SB } & \text { WB } \\ \text { AM } & 0.833 & & 0.973 & 0.931 \\ \text { PM } & 0.841 & & 0.926 & 0.857\end{array}$

Intersection Peak Hour Factors

AM

0.913

PM

0.889 


\section{City of Toronto - Traffic Safety Unit}

\section{Peak Hour Factor Calculations Report}

$\begin{array}{lll}\text { Survey Date: } & \text { Jul-27-2011 } & \text { (Wednesday) } \\ \text { Survey Type: } & \text { Routine Hours } & \end{array}$

BLUE JAYS WAY AT WELLINGTON ST (PX 1682)

Movement Peak Hour Factors

\begin{tabular}{|c|c|c|c|c|}
\hline & NB_Thru & NB_Right & NB_Left & EB_Thru \\
\hline AM & 0.942 & & 0.650 & \\
\hline PM & 0.724 & & 0.639 & \\
\hline \multicolumn{5}{|c|}{ Peak Hour Factors } \\
\hline & NB & EB & SB & WB \\
\hline AM & 0.945 & 0.667 & 0.960 & 0.842 \\
\hline PM & 0.717 & 0.783 & 0.713 & 0.875 \\
\hline
\end{tabular}

Intersection Peak Hour Factors

AM

0.943

PM

0.887 


\section{Turning Movement Count Summary Report}

CHURCH ST AT FRONT ST \& WELLINGTON ST (PX 15)

Survey Date:

2009-Apr-23

(Thursday)

Time

$\begin{array}{llll}\text { Time Vehicle NORTHBOUND } & \text { EASTBOUND } & \text { SOUTHBOUND }\end{array}$

Survey Type:

Routine Hours

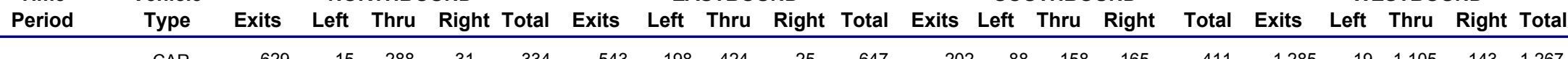

\begin{tabular}{|c|c|c|c|c|c|c|c|c|c|c|c|c|c|c|c|c|c|c|c|c|c|c|c|c|c|}
\hline & CAR & 629 & 15 & 288 & 31 & 334 & 543 & 198 & 424 & 25 & 647 & 202 & 88 & 158 & 165 & 411 & 1,285 & 19 & 1,105 & 143 & 1,267 & $\mathrm{~N}$ & 390 & 0 & 0 \\
\hline $08: 30-09: 30$ & TRK & 18 & 0 & 6 & 0 & 6 & 13 & 6 & 11 & 0 & 17 & 3 & 2 & 3 & 8 & 13 & 33 & 0 & 25 & 6 & 31 & $s$ & 344 & 0 & 0 \\
\hline AM PEAK & BUS & 4 & 1 & 2 & 1 & 4 & 7 & 1 & 5 & 1 & 7 & 1 & 1 & 0 & 2 & 3 & 10 & 0 & 7 & 1 & 8 & $E$ & 196 & 0 & 0 \\
\hline
\end{tabular}

\begin{tabular}{|c|c|c|c|c|c|c|c|c|c|c|c|c|c|c|c|c|c|c|c|c|c|c|c|c|c|}
\hline & TOTAL: & 651 & 16 & 296 & 32 & 344 & 563 & 205 & 440 & 26 & 671 & 206 & 91 & 161 & 175 & 427 & 1,328 & 19 & 1,137 & 150 & 1,306 & & & & \\
\hline \multirow{2}{*}{ 17:00-18:00 } & CAR & 465 & 8 & 233 & 99 & 340 & 1,319 & 160 & 1,115 & 35 & 1,310 & 381 & 105 & 304 & 264 & 673 & 1,030 & 42 & 758 & 72 & 872 & $\mathrm{~N}$ & 577 & 0 & 0 \\
\hline & TRK & 3 & 0 & 1 & 0 & 1 & 4 & 1 & 3 & 2 & 6 & 3 & 1 & 1 & 20 & 22 & 31 & 0 & 11 & 1 & 12 & $S$ & 920 & 0 & 0 \\
\hline PM PEAK & BUS & 1 & 0 & 1 & 0 & 1 & 5 & 0 & 5 & 0 & 5 & 1 & 0 & 1 & 3 & 4 & 9 & 0 & 6 & 0 & 6 & $\begin{array}{l}E \\
W\end{array}$ & $\begin{array}{l}204 \\
465\end{array}$ & $\begin{array}{l}0 \\
0\end{array}$ & $\begin{array}{l}0 \\
0\end{array}$ \\
\hline
\end{tabular}

\begin{tabular}{|c|c|c|c|c|c|c|c|c|c|c|c|c|c|c|c|c|c|c|c|c|c|c|c|c|c|}
\hline & TOTAL: & 469 & 8 & 235 & 99 & 342 & 1,328 & 161 & 1,123 & 37 & 1,321 & 385 & 106 & 306 & 287 & 699 & 1,070 & 42 & 775 & 73 & 890 & & & & \\
\hline \multirow{3}{*}{$\begin{array}{l}\text { OFF HR } \\
\text { AVG }\end{array}$} & CAR & 343 & 15 & 114 & 38 & 167 & 502 & 158 & 389 & 39 & 586 & 183 & 75 & 119 & 139 & 333 & 571 & 25 & 417 & 71 & 513 & $\mathrm{~N}$ & 199 & 0 & 0 \\
\hline & TRK & 16 & 1 & 3 & 2 & 6 & 30 & 7 & 24 & 2 & 33 & 6 & 4 & 3 & 11 & 18 & 24 & 1 & 12 & 6 & 19 & $\mathrm{~s}$ & 386 & 0 & 0 \\
\hline & BUS & 3 & 2 & 1 & 1 & 4 & 6 & 1 & 5 & 2 & 8 & 3 & 0 & 0 & 1 & 1 & 6 & 1 & 3 & 1 & 5 & $\begin{array}{l}E \\
W\end{array}$ & $\begin{array}{l}159 \\
193\end{array}$ & $\begin{array}{l}0 \\
0\end{array}$ & $\begin{array}{l}0 \\
0\end{array}$ \\
\hline
\end{tabular}

\begin{tabular}{|c|c|c|c|c|c|c|c|c|c|c|c|c|c|c|c|c|c|c|c|c|c|c|c|c|c|}
\hline & TOTAL: & 362 & 18 & 118 & 41 & 177 & 538 & 166 & 418 & 43 & 627 & 192 & 79 & 122 & 151 & 352 & 601 & 27 & 432 & 78 & 537 & & & & \\
\hline $07 \cdot 30-09 \cdot 30$ & CAR & 1,079 & 36 & 489 & 52 & 577 & 873 & 337 & 669 & 48 & 1,054 & 408 & 152 & 301 & 282 & 735 & 2,301 & 59 & 1,983 & 253 & 2,295 & $\mathrm{~N}$ & 486 & 0 & 0 \\
\hline $01: 30-09: 50$ & TRK & 31 & 1 & 9 & 0 & 10 & 24 & 16 & 21 & 0 & 37 & 5 & 3 & 5 & 10 & 18 & 47 & 0 & 36 & 6 & 42 & $S$ & 489 & 0 & 0 \\
\hline 2 HR AM & BUS & 7 & 3 & 4 & 1 & 8 & 9 & 2 & 6 & 3 & 11 & 4 & 2 & 1 & 2 & 5 & 13 & 0 & 8 & 1 & 9 & $\begin{array}{l}E \\
W\end{array}$ & $\begin{array}{l}242 \\
432\end{array}$ & $\begin{array}{l}0 \\
0\end{array}$ & $\begin{array}{l}0 \\
0\end{array}$ \\
\hline
\end{tabular}

\begin{tabular}{|c|c|c|c|c|c|c|c|c|c|c|c|c|c|c|c|c|c|c|c|c|c|c|c|c|c|}
\hline & TOTAL: & 1,117 & 40 & 502 & 53 & 595 & 906 & 355 & 696 & 51 & 1,102 & 417 & $\overline{157}$ & 307 & $\overline{294}$ & $\overline{758}$ & 2,361 & 59 & $\overline{2,027}$ & 260 & 2,346 & & & & \\
\hline & CAR & 792 & 46 & 362 & 141 & 549 & 2,037 & 295 & 1,702 & 84 & 2,081 & 616 & 194 & 459 & 360 & 1,013 & 1,545 & 73 & 1,139 & 135 & 1,347 & $\mathrm{~N}$ & 697 & 0 & $\overline{0}$ \\
\hline 16:00-18:00 & TRK & 8 & 0 & 3 & 0 & 3 & 21 & 3 & 18 & 3 & 24 & 7 & 3 & 3 & 28 & 34 & 50 & 1 & 22 & 2 & 25 & $\mathrm{~s}$ & 1,078 & 0 & 0 \\
\hline 2 HR PM & BUS & 2 & 0 & 1 & 1 & 2 & 12 & 1 & 10 & 9 & 20 & 12 & 1 & 2 & 3 & 6 & 12 & 1 & 9 & 0 & 10 & $\begin{array}{c}E \\
W\end{array}$ & $\begin{array}{l}244 \\
640\end{array}$ & $\begin{array}{l}0 \\
0\end{array}$ & $\begin{array}{l}0 \\
0\end{array}$ \\
\hline
\end{tabular}

\begin{tabular}{|c|c|c|c|c|c|c|c|c|c|c|c|c|c|c|c|c|c|c|c|c|c|c|c|c|c|}
\hline & TOTAL: & 802 & 46 & 366 & 142 & 554 & 2,070 & 299 & 1,730 & 96 & 2,125 & 635 & 198 & 464 & 391 & 1,053 & 1,607 & 75 & 1,170 & 137 & 1,382 & & & & \\
\hline \multirow{2}{*}{ 07:30-18:00 } & CAR & 3,241 & 141 & 1,306 & 346 & 1,793 & 4,916 & 1,264 & 3,926 & 287 & 5,477 & 1,754 & 644 & 1,237 & 1,196 & 3,077 & 6,128 & 230 & 4,791 & 671 & 5,692 & $N$ & 1,978 & 0 & 0 \\
\hline & TRK & 102 & 6 & 25 & 8 & 39 & 164 & 46 & 136 & 9 & 191 & 33 & 20 & 19 & 82 & 121 & 193 & 5 & 105 & 31 & 141 & $s$ & 3,109 & 0 & 0 \\
\hline \multirow[t]{3}{*}{8 HR SUM } & BUS & 18 & 9 & 9 & 5 & 23 & 44 & 5 & 35 & 19 & 59 & 27 & 4 & 4 & 9 & 17 & 46 & 4 & 28 & 4 & 36 & $E$ & 1,122 & 0 & 0 \\
\hline & -- & - & - & - & - & - & - & - & - & - & - - & - & - & - & - & - & - &  & - & 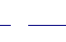 & -- & W & $-1,844$ & 0 & - \\
\hline & TOTAL: & 3,361 & 156 & 1,340 & 359 & 1,855 & 5,124 & 1,315 & 4,097 & 315 & 5,727 & 1,814 & 668 & 1,260 & 1,287 & 3,215 & 6,367 & 239 & 4,924 & 706 & 5,869 & & & & \\
\hline
\end{tabular}




\section{Turning Movement Count Summary Report}

WELLINGTON ST AT YONGE ST (PX 30)

\section{Survey Date:}

2014-May-06

(Tuesday)

Time

NORTHBOUND Survey Type:

Routine Hours



\begin{tabular}{|c|c|c|c|c|c|c|c|c|c|c|c|c|c|c|c|c|c|c|c|c|c|c|c|c|}
\hline \multirow{2}{*}{ 07:3c } & CAR & 411 & 291 & 368 & 0 & 659 & 0 & 0 & 0 & 0 & 0 & 316 & 0 & 232 & 164 & 396 & 1,328 & 84 & 873 & 43 & 1,000 & $\mathrm{~N}$ & 737 & 27 \\
\hline & TRK & 27 & 13 & 22 & 0 & 35 & 0 & 0 & 0 & 0 & 0 & 20 & 0 & 18 & 5 & 23 & 50 & 2 & 32 & 5 & 39 & $S$ & 602 & 15 \\
\hline AM PEAK & BUS & 3 & 1 & 3 & 0 & 4 & 0 & 0 & 0 & 0 & 0 & 7 & 0 & 7 & 17 & 24 & 21 & 0 & 3 & 0 & 3 & $\begin{array}{l}E \\
W\end{array}$ & $\begin{array}{r}884 \\
1,054\end{array}$ & $\begin{array}{r}32 \\
0\end{array}$ \\
\hline
\end{tabular}

\begin{tabular}{|c|c|c|c|c|c|c|c|c|c|c|c|c|c|c|c|c|c|c|c|c|c|c|c|c|c|}
\hline & TOTAL: & 441 & 305 & 393 & 0 & 698 & 0 & 0 & 0 & 0 & 0 & 343 & 0 & 257 & 186 & 443 & 1,399 & 86 & 908 & 48 & 1,042 & & & & \\
\hline \multirow{2}{*}{ 17:00-18:00 } & CAR & 468 & 137 & 388 & 0 & 525 & 0 & 0 & 0 & 0 & 0 & 421 & 0 & 300 & 105 & 405 & 672 & 121 & 430 & 80 & 631 & $\mathrm{~N}$ & 824 & 38 & 0 \\
\hline & TRK & 11 & 8 & 7 & 0 & 15 & 0 & 0 & 0 & 0 & 0 & 10 & 0 & 6 & 3 & 9 & 21 & 4 & 10 & 4 & 18 & $\mathrm{~s}$ & 1,039 & 28 & 0 \\
\hline PM PEAK & BUS & 2 & 1 & 2 & 0 & 3 & 0 & 0 & 0 & 0 & 0 & 6 & 0 & 5 & 19 & 24 & 23 & 1 & 3 & 0 & 4 & $\begin{array}{l}E \\
W\end{array}$ & $\begin{array}{l}1,783 \\
1,890\end{array}$ & $\begin{array}{r}28 \\
0\end{array}$ & $\begin{array}{l}0 \\
0\end{array}$ \\
\hline
\end{tabular}

\begin{tabular}{|c|c|c|c|c|c|c|c|c|c|c|c|c|c|c|c|c|c|c|c|c|c|c|c|c|c|}
\hline & TOTAL: & 481 & 146 & 397 & 0 & 543 & 0 & 0 & 0 & 0 & 0 & 437 & 0 & 311 & 127 & 438 & 716 & 126 & 443 & 84 & 653 & & & & \\
\hline \multirow{3}{*}{$\begin{array}{l}\text { OFF HR } \\
\text { AVG }\end{array}$} & CAR & 381 & 173 & 341 & 0 & 514 & 0 & 0 & 0 & 0 & 0 & 386 & 0 & 282 & 126 & 408 & 692 & 104 & 393 & 40 & 537 & $\mathrm{~N}$ & 420 & 18 & 0 \\
\hline & TRK & 15 & 10 & 12 & 0 & 22 & 0 & 0 & 0 & 0 & 0 & 31 & 0 & 23 & 8 & 31 & 38 & 8 & 20 & 3 & 31 & $S$ & 470 & 12 & 0 \\
\hline & BUS & 1 & 1 & 1 & 0 & 2 & 0 & 0 & 0 & 0 & 0 & 4 & 0 & 3 & 11 & 14 & 15 & 1 & 3 & 0 & 4 & $\mathrm{E}$ & 605 & 16 & 0 \\
\hline
\end{tabular}

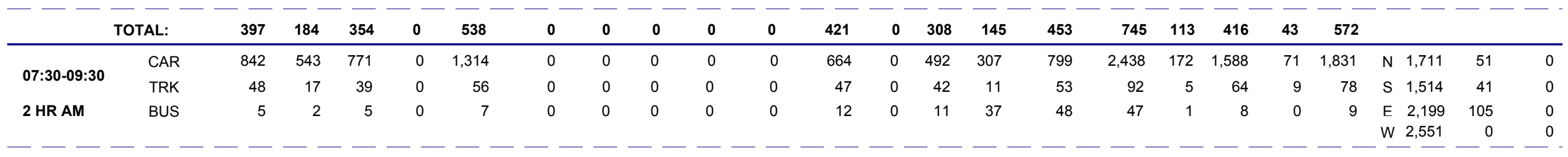

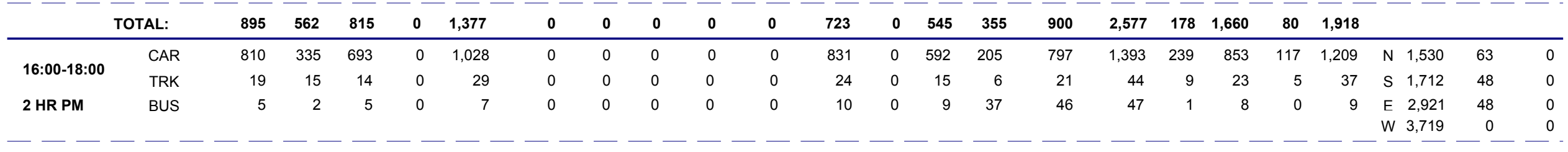






\section{Turning Movement Count Summary Report}

BAY ST AT WELLINGTON ST (PX 60)

\section{Survey Date:}

2009-Aug-12

(Wednesday)

Survey Type:

Routine Hours

$\begin{array}{llll}\text { Time Vehicle NORTHBOUND SOUTHBOUND } & \text { WASTBOUND }\end{array}$

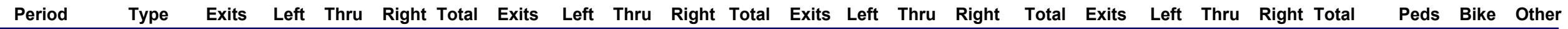

\begin{tabular}{|c|c|c|c|c|c|c|c|c|c|c|c|c|c|c|c|c|c|c|c|c|c|c|c|c|c|}
\hline $07 \cdot 2$ & CAR & 736 & 139 & 706 & 0 & 845 & 0 & 0 & 0 & 0 & 0 & 459 & 0 & 393 & 149 & 542 & 1,382 & 66 & 1,094 & 30 & 1,190 & $N$ & 416 & 0 & 0 \\
\hline $01.00-00.00$ & TRK & 33 & 3 & 29 & 0 & 32 & 0 & 0 & 0 & 0 & 0 & 21 & 0 & 17 & 5 & 22 & 23 & 4 & 15 & 4 & 23 & $s$ & 1,217 & 0 & 0 \\
\hline AM PEAK & BUS & 9 & 0 & 9 & 0 & 9 & 0 & 0 & 0 & 0 & 0 & 13 & 0 & 8 & 0 & 8 & 10 & 5 & 10 & 0 & 15 & $\begin{array}{l}E \\
W\end{array}$ & $\begin{array}{l}2,461 \\
2,596\end{array}$ & $\begin{array}{l}0 \\
0\end{array}$ & 0 \\
\hline
\end{tabular}

\begin{tabular}{rrrrrrr} 
& TOTAL: & $\mathbf{7 7 8}$ & $\mathbf{1 4 2}$ & $\mathbf{7 4 4}$ & $\mathbf{0}$ & $\mathbf{8}$ \\
\hline \multirow{2}{*}{ 17:00-18:00 } & CAR & 404 & 41 & 367 & 0 & 4 \\
\multirow{2}{*}{ PM PEAK } & TRK & 4 & 0 & 4 & 0 \\
& BUS & 13 & 0 & 12 & 0
\end{tabular}

\begin{tabular}{|c|c|c|c|c|c|c|c|c|c|c|c|c|c|c|c|c|c|c|c|c|c|c|c|c|c|}
\hline & TOTAL: & 421 & 41 & 383 & 0 & 424 & 0 & 0 & 0 & 0 & 0 & 929 & 0 & 805 & 68 & 873 & 765 & 124 & 656 & 38 & 818 & & & & \\
\hline \multirow{3}{*}{$\begin{array}{l}\text { OFF HR } \\
\text { AVG }\end{array}$} & CAR & 504 & 52 & 457 & 0 & 509 & 0 & 0 & 0 & 0 & 0 & 534 & 0 & 464 & 109 & 573 & 619 & 70 & 458 & 47 & 575 & $\mathrm{~N}$ & 299 & 0 & 0 \\
\hline & TRK & 29 & 12 & 23 & 0 & 35 & 0 & 0 & 0 & 0 & 0 & 33 & 0 & 28 & 6 & 34 & 35 & 5 & 17 & 6 & 28 & $\mathrm{~s}$ & 509 & 0 & 0 \\
\hline & BUS & 12 & 1 & 12 & 0 & 13 & 0 & 0 & 0 & 0 & 0 & 15 & 0 & 12 & 0 & 12 & 4 & 3 & 3 & 0 & 6 & $\mathrm{E}$ & 500 & 0 & 0 \\
\hline
\end{tabular}

\begin{tabular}{|c|c|c|c|c|c|c|c|c|c|c|c|c|c|c|c|c|c|c|c|c|c|c|c|c|c|}
\hline & TOTAL: & 545 & 65 & 492 & 0 & 557 & 0 & 0 & 0 & 0 & 0 & 582 & 0 & 504 & 115 & 619 & 658 & 78 & 478 & 53 & 609 & & & & \\
\hline 30 & CAR & 1,425 & 245 & 1,351 & 0 & 1,596 & 0 & 0 & 0 & 0 & 0 & 899 & 0 & 760 & 284 & 1,044 & 2,493 & 139 & 1,964 & 74 & 2,177 & $\mathrm{~N}$ & 649 & 0 & 0 \\
\hline (3.000 & TRK & 59 & 7 & 55 & 0 & 62 & 0 & 0 & 0 & 0 & 0 & 44 & 0 & 38 & 9 & 47 & 55 & 6 & 39 & 4 & 49 & $S$ & 1,931 & 0 & 0 \\
\hline 2 HR AM & BUS & 22 & 1 & 21 & 0 & 22 & 0 & 0 & 0 & 0 & 0 & 35 & 0 & 26 & 0 & 26 & 24 & 9 & 23 & 1 & 33 & $\mathrm{E}$ & $\begin{array}{l}3,773 \\
4215\end{array}$ & 0 & $\begin{array}{l}0 \\
0\end{array}$ \\
\hline
\end{tabular}

\begin{tabular}{|c|c|c|c|c|c|c|c|c|c|c|c|c|c|c|c|c|c|c|c|c|c|c|c|c|c|}
\hline & TOTAL: & 1,506 & 253 & 1,427 & 0 & 1,680 & 0 & 0 & 0 & 0 & 0 & 978 & 0 & 824 & 293 & 1,117 & 2,572 & 154 & 2,026 & 79 & 2,259 & & & & \\
\hline $16 \cdot 00-18 \cdot 00$ & CAR & 852 & 91 & 744 & 0 & 835 & 0 & 0 & 0 & 0 & 0 & 1,522 & 0 & 1,310 & 142 & 1,452 & 1,482 & 212 & 1,249 & 108 & 1,569 & $N$ & 997 & 0 & 0 \\
\hline $16: 00-18: 00$ & TRK & 11 & 1 & 11 & 0 & 12 & 0 & 0 & 0 & 0 & 0 & 32 & 0 & 25 & 4 & 29 & 16 & 7 & 11 & 0 & 18 & $S$ & 1,397 & 0 & 0 \\
\hline 2 HR PM & BuS & 34 & 1 & 30 & 0 & 31 & 0 & 0 & 0 & 0 & 0 & 36 & 0 & 22 & 0 & 22 & 23 & 14 & 22 & 4 & 40 & $\begin{array}{l}\mathrm{E} \\
\mathrm{W}\end{array}$ & $\begin{array}{l}4,098 \\
6,758\end{array}$ & $\begin{array}{l}0 \\
0\end{array}$ & $\begin{array}{l}0 \\
0\end{array}$ \\
\hline
\end{tabular}

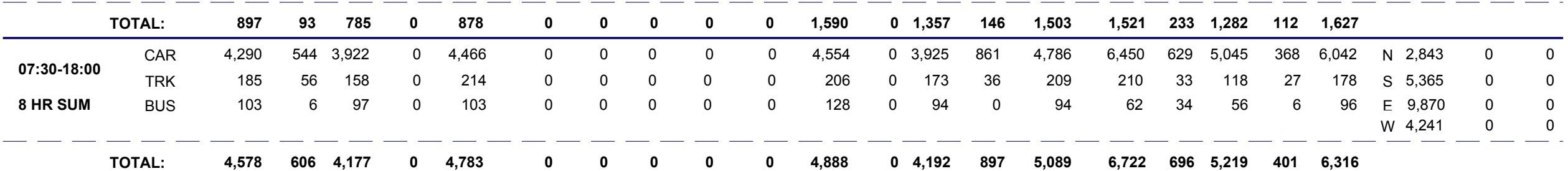




\section{Turning Movement Count Summary Report}

WELLINGTON ST AT YORK ST (PX 71)

\section{Survey Date:}

2012-Aug-07

(Tuesday)

Time

RTHBOUND Survey Type:

Routine Hours

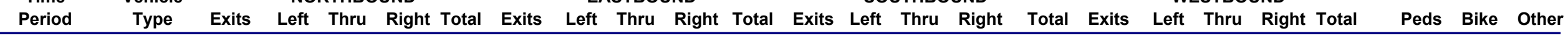

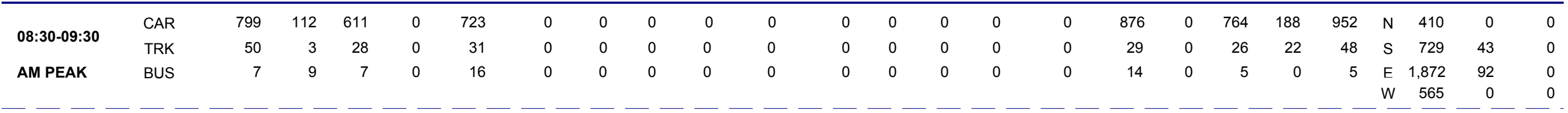

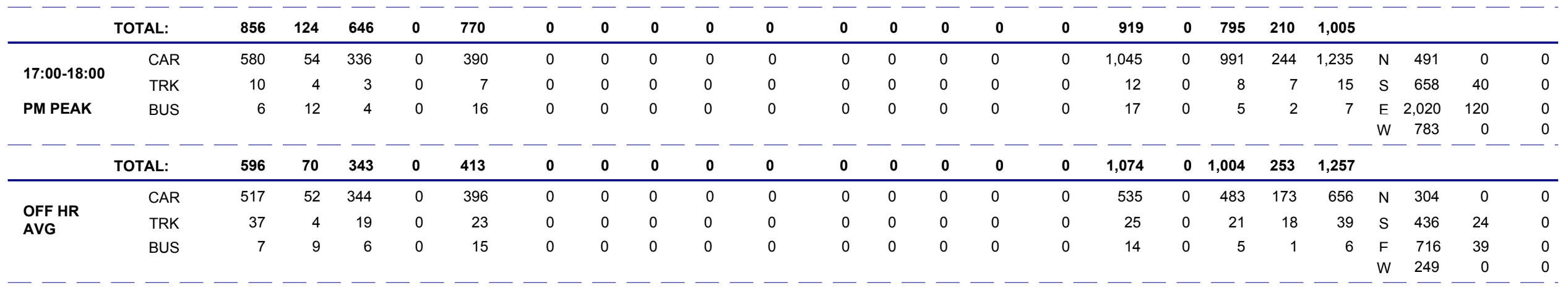

\begin{tabular}{|c|c|c|c|c|c|c|c|c|c|c|c|c|c|c|c|c|c|c|c|c|c|c|c|c|c|}
\hline & TOTAL: & 561 & 65 & 369 & 0 & 434 & 0 & 0 & 0 & 0 & 0 & 0 & 0 & 0 & 0 & 0 & 574 & 0 & 509 & 192 & 701 & & & & \\
\hline \multirow{2}{*}{ 07:30-09:30 } & CAR & 1,472 & 221 & 1,106 & 0 & 1,327 & 0 & 0 & 0 & 0 & 0 & 0 & 0 & 0 & 0 & 0 & 1,602 & 0 & 1,381 & 366 & 1,747 & $\mathrm{~N}$ & 660 & 0 & 0 \\
\hline & TRK & 97 & 4 & 55 & 0 & 59 & 0 & 0 & 0 & 0 & 0 & 0 & 0 & 0 & 0 & 0 & 52 & 0 & 48 & 42 & 90 & $S$ & 1,187 & 76 & 0 \\
\hline 2 HR AM & BUS & 14 & 19 & 14 & 0 & 33 & 0 & 0 & 0 & 0 & 0 & 0 & 0 & 0 & 0 & 0 & 28 & 0 & 9 & 0 & 9 & $\begin{array}{l}E \\
W\end{array}$ & $\begin{array}{l}4,016 \\
1,036\end{array}$ & $\begin{array}{r}151 \\
0\end{array}$ & $\begin{array}{l}0 \\
0\end{array}$ \\
\hline
\end{tabular}

\begin{tabular}{|c|c|c|c|c|c|c|c|c|c|c|c|c|c|c|c|c|c|c|c|c|c|c|c|c|c|}
\hline & TOTAL: & 1,583 & 244 & 1,175 & 0 & 1,419 & 0 & 0 & 0 & 0 & 0 & 0 & 0 & 0 & 0 & 0 & 1,682 & 0 & 1,438 & 408 & 1,846 & & & & \\
\hline & CAR & 1,078 & 121 & 626 & 0 & 747 & 0 & 0 & 0 & 0 & 0 & 0 & 0 & 0 & 0 & 0 & 1,908 & 0 & 1,787 & 452 & 2,239 & $\mathrm{~N}$ & 823 & 0 & 0 \\
\hline $10: 00-10: 00$ & TRK & 23 & 4 & 10 & 0 & 14 & 0 & 0 & 0 & 0 & 0 & 0 & 0 & 0 & 0 & 0 & 24 & 0 & 20 & 13 & 33 & $S$ & 1,216 & 85 & 0 \\
\hline 2 HR PM & BUS & 10 & 26 & 8 & 0 & 34 & 0 & 0 & 0 & 0 & 0 & 0 & 0 & 0 & 0 & 0 & 37 & 0 & 11 & 2 & 13 & $\begin{array}{l}E \\
W\end{array}$ & $\begin{array}{l}4,274 \\
1,643\end{array}$ & $\begin{array}{r}200 \\
0\end{array}$ & $\begin{array}{l}0 \\
0\end{array}$ \\
\hline
\end{tabular}

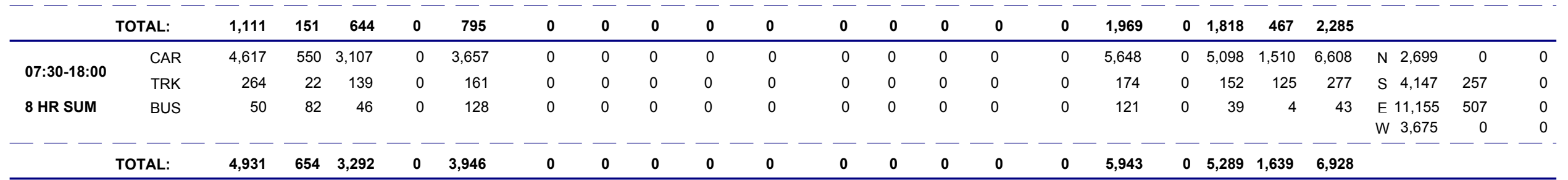

Total 8 Hour Vehicle Volume: 10,874

Total 8 Hour Bicycle Volume: 764

Total 8 Hour Intersection Volume: 11,638

Comment: 


\section{Turning Movement Count Summary Report}

UNIVERSITY AVE AT WELLINGTON ST (PX 76)

\section{Survey Date:}

2011-May-05

(Thursday)

Time Vehicle

NORTHBOUND

EASTBOUND Survey Type:

Routine Hours

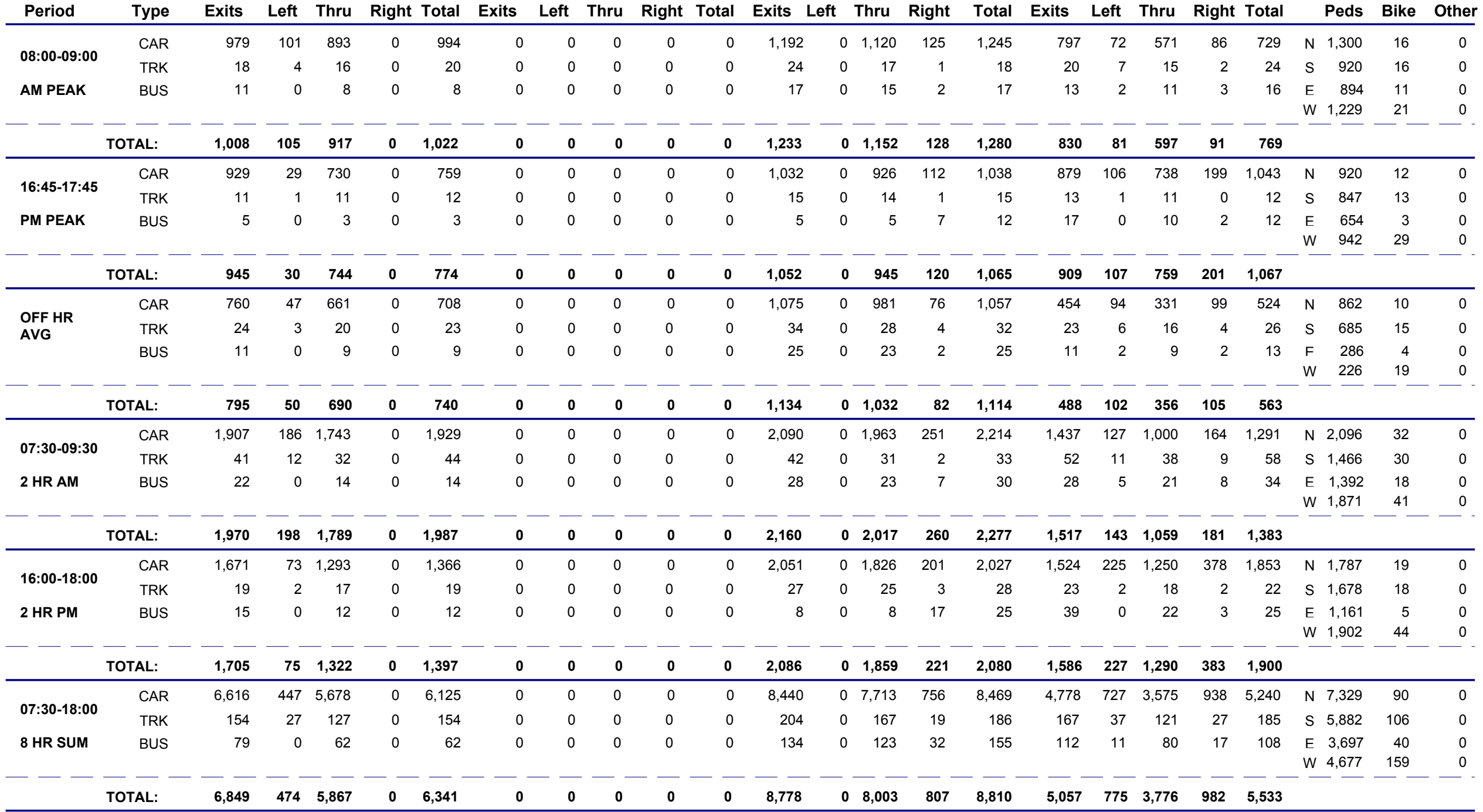




\section{Turning Movement Count Summary Report}

SIMCOE ST AT WELLINGTON ST (PX 264)

\section{Survey Date:}

2009-Nov-26

(Thursday)

Time Vehicle

Survey Type:

Routine Hours

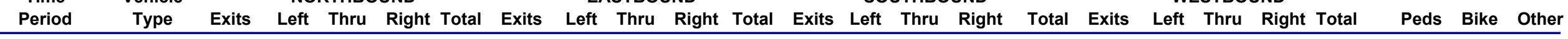

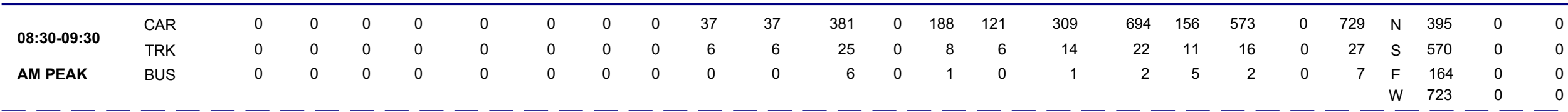

\begin{tabular}{|c|c|c|c|c|c|c|c|c|c|c|c|c|c|c|c|c|c|c|c|c|c|c|c|c|c|}
\hline & TOTAL: & 0 & 0 & 0 & 0 & 0 & 0 & 0 & 0 & 43 & 43 & 412 & 0 & 197 & 127 & 324 & 718 & 172 & 591 & 0 & 763 & & & & \\
\hline \multirow{2}{*}{ 17:00-18:00 } & CAR & 0 & 0 & 0 & 0 & 0 & 0 & 0 & 0 & 205 & 205 & 973 & 0 & 546 & 86 & 632 & 649 & 222 & 563 & 0 & 785 & $N$ & 351 & 0 & 0 \\
\hline & TRK & 0 & 0 & 0 & 0 & 0 & 0 & 0 & 0 & 2 & 2 & 17 & 0 & 11 & 0 & 11 & 6 & 4 & 6 & 0 & 10 & $S$ & 709 & 0 & 0 \\
\hline PM PEAK & BUS & 0 & 0 & 0 & 0 & 0 & 0 & 0 & 0 & 0 & 0 & 24 & 0 & 9 & 0 & 9 & 5 & 15 & 5 & 0 & 20 & $E$ & 305 & 0 & 0 \\
\hline
\end{tabular}

\begin{tabular}{|c|c|c|c|c|c|c|c|c|c|c|c|c|c|c|c|c|c|c|c|c|c|c|c|c|c|}
\hline & TOTAL: & 0 & 0 & 0 & 0 & 0 & 0 & 0 & 0 & 207 & 207 & 1,014 & 0 & 566 & 86 & 652 & 660 & 241 & 574 & 0 & 815 & & & & \\
\hline \multirow{3}{*}{$\begin{array}{l}\text { OFF HR } \\
\text { AVG }\end{array}$} & CAR & 0 & 0 & 0 & 0 & 0 & 0 & 0 & 0 & 58 & 58 & 321 & 0 & 174 & 87 & 261 & 403 & 89 & 316 & 0 & 405 & $\mathrm{~N}$ & 315 & 0 & 0 \\
\hline & TRK & 0 & 0 & 0 & 0 & 0 & 0 & 0 & 0 & 5 & 5 & 28 & 0 & 14 & 4 & 18 & 20 & 9 & 16 & 0 & 25 & $s$ & 373 & 0 & 0 \\
\hline & BUS & 0 & 0 & 0 & 0 & 0 & 0 & 0 & 0 & 0 & 0 & 8 & 0 & 2 & 0 & 2 & 1 & 6 & 1 & 0 & 7 & $\begin{array}{l}E \\
W\end{array}$ & $\begin{array}{r}95 \\
303\end{array}$ & $\begin{array}{l}0 \\
0\end{array}$ & $\begin{array}{l}0 \\
0\end{array}$ \\
\hline
\end{tabular}

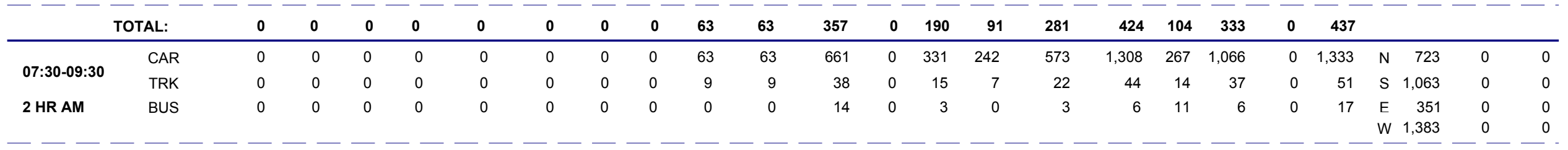

\begin{tabular}{|c|c|c|c|c|c|c|c|c|c|c|c|c|c|c|c|c|c|c|c|c|c|c|c|c|c|}
\hline & TOTAL: & 0 & 0 & 0 & 0 & 0 & 0 & 0 & 0 & 72 & 72 & 713 & 0 & 349 & 249 & 598 & 1,358 & 292 & 1,109 & 0 & 1,401 & & & & \\
\hline \multirow{2}{*}{$16: 00-18: 00$} & CAR & 0 & 0 & 0 & 0 & 0 & 0 & 0 & 0 & 448 & 448 & 1,902 & 0 & 1,045 & 175 & 1,220 & 1,159 & 409 & 984 & 0 & 1,393 & $\mathrm{~N}$ & 704 & 0 & 0 \\
\hline & TRK & 0 & 0 & 0 & 0 & 0 & 0 & 0 & 0 & 6 & 6 & 52 & 0 & 32 & 1 & 33 & 20 & 14 & 19 & 0 & 33 & $\mathrm{~s}$ & 1,312 & 0 & 0 \\
\hline 2 HR PM & BUS & 0 & 0 & 0 & 0 & 0 & 0 & 0 & 0 & 0 & 0 & 49 & 0 & 17 & 0 & 17 & 5 & 32 & 5 & 0 & 37 & $\begin{array}{l}E \\
W\end{array}$ & $\begin{array}{l}642 \\
912\end{array}$ & $\begin{array}{l}0 \\
0\end{array}$ & $\begin{array}{l}0 \\
0\end{array}$ \\
\hline
\end{tabular}

\begin{tabular}{|c|c|c|c|c|c|c|c|c|c|c|c|c|c|c|c|c|c|c|c|c|c|c|c|c|c|}
\hline & TOTAL: & 0 & 0 & 0 & 0 & 0 & 0 & 0 & 0 & 454 & 454 & 2,003 & 0 & 1,094 & 176 & 1,270 & 1,184 & 455 & 1,008 & 0 & 1,463 & & & & \\
\hline \multirow{2}{*}{ 07:30-18:00 } & CAR & 0 & 0 & 0 & 0 & 0 & 0 & 0 & 0 & 743 & 743 & 3,848 & 0 & 2,072 & 763 & 2,835 & 4,078 & 1,033 & 3,315 & 0 & 4,348 & $\mathrm{~N}$ & 2,685 & 0 & 0 \\
\hline & TRK & 0 & 0 & 0 & 0 & 0 & 0 & 0 & 0 & 33 & 33 & 200 & 0 & 103 & 25 & 128 & 144 & 64 & 119 & 0 & 183 & $S$ & 3,865 & 0 & 0 \\
\hline \multirow[t]{2}{*}{8 HR SUM } & BUS & 0 & 0 & 0 & 0 & 0 & 0 & 0 & 0 & 0 & 0 & 96 & 0 & 28 & 0 & 28 & 15 & 68 & 15 & 0 & 83 & $\begin{array}{l}E \\
W\end{array}$ & $\begin{array}{l}1,372 \\
3,506\end{array}$ & $\begin{array}{l}0 \\
0\end{array}$ & $\begin{array}{l}0 \\
0\end{array}$ \\
\hline & TOTAL: & 0 & 0 & 0 & 0 & 0 & 0 & 0 & 0 & 776 & 776 & 4,144 & 0 & 2,203 & 788 & 2,991 & 4,237 & 1,165 & 3,449 & 0 & 4,614 & & & & \\
\hline
\end{tabular}




\section{Turning Movement Count Summary Report}

JOHN ST AT WELLINGTON ST (PX 1489)

Survey Date:

Survey Type:

2009-Apr-23

(Thursday)

$\begin{array}{llll}\text { Time Vehicle NORTHBOUND } & \text { EASTBOUND } & \text { SOUTHBOUND }\end{array}$

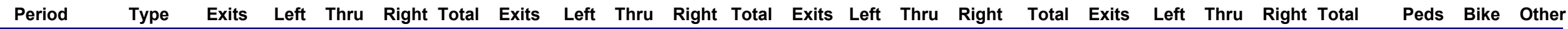

\begin{tabular}{|c|c|c|c|c|c|c|c|c|c|c|c|c|c|c|c|c|c|c|c|c|c|c|c|c|}
\hline & CAR & 513 & 15 & 374 & 264 & 653 & 356 & 0 & 0 & 0 & 0 & 285 & 92 & 251 & 54 & 397 & 365 & 34 & 296 & 139 & 469 & $\mathrm{~N}$ & 779 & 1 \\
\hline $08: 15-09: 15$ & TRK & 16 & 0 & 6 & 11 & 17 & 11 & 0 & 0 & 0 & 0 & 7 & 0 & 5 & 1 & 6 & 9 & 2 & 8 & 10 & 20 & $S$ & 606 & 1 \\
\hline AM PEAK & BUS & 2 & 0 & 1 & 2 & 3 & 2 & 0 & 0 & 0 & 0 & 2 & 0 & 2 & 0 & 2 & 7 & 0 & 7 & 1 & 8 & $\mathrm{E}$ & 978 & 0 \\
\hline
\end{tabular}

\begin{tabular}{|c|c|c|c|c|c|c|c|}
\hline & TOTAL: & 531 & 15 & 381 & 277 & 673 & 369 \\
\hline \multirow{2}{*}{$17: 00-18: 00$} & CAR & 735 & 27 & 450 & 24 & 501 & 47 \\
\hline & TRK & 5 & 2 & 3 & 0 & 5 & 1 \\
\hline PM PEAK & BUS & 4 & 0 & 4 & 0 & 4 & 0 \\
\hline
\end{tabular}

\begin{tabular}{|c|c|c|c|c|c|c|c|c|c|c|c|c|c|c|c|c|c|c|c|c|c|c|c|c|c|}
\hline & TOTAL: & 744 & 29 & 457 & 24 & 510 & 48 & 0 & 0 & 0 & 0 & 518 & 24 & 340 & 130 & $\overline{494}$ & 965 & 178 & 806 & 287 & 1,271 & & & & \\
\hline \multirow{3}{*}{$\begin{array}{l}\text { OFF HR } \\
\text { AVG }\end{array}$} & CAR & 348 & 14 & 236 & 48 & 298 & 66 & 0 & 0 & 0 & 0 & 283 & 18 & 233 & 34 & 285 & 308 & 50 & 260 & 112 & 422 & $\mathrm{~N}$ & 286 & 1 & 0 \\
\hline & TRK & 16 & 0 & 7 & 3 & 10 & 4 & 0 & 0 & 0 & 0 & 8 & 1 & 6 & 2 & 9 & 15 & 2 & 13 & 9 & 24 & $\mathrm{~s}$ & 176 & 0 & 0 \\
\hline & BUS & 2 & 0 & 1 & 1 & 2 & 1 & 0 & 0 & 0 & 0 & 1 & 0 & 1 & 0 & 1 & 4 & 0 & 4 & 1 & 5 & $\mathrm{E}$ & 421 & 0 & 0 \\
\hline
\end{tabular}

\begin{tabular}{|c|c|c|c|c|c|c|c|c|c|c|c|c|c|c|c|c|c|c|c|c|c|c|c|c|c|}
\hline & TOTAL: & 366 & 14 & 244 & 52 & 310 & 71 & 0 & 0 & 0 & 0 & 292 & 19 & 240 & 36 & 295 & 327 & 52 & 277 & 122 & 451 & & & & \\
\hline \multirow{2}{*}{ 07:30-09:30 } & CAR & 833 & 24 & 587 & 386 & 997 & 525 & 0 & 0 & 0 & 0 & 464 & 139 & 380 & 93 & 612 & 629 & 84 & 512 & 246 & 842 & $\mathrm{~N}$ & 1,135 & 4 & 0 \\
\hline & TRK & 26 & 0 & 8 & 14 & 22 & 15 & 0 & 0 & 0 & 0 & 13 & 1 & 9 & 3 & 13 & 25 & 4 & 22 & 18 & 44 & $\mathrm{~s}$ & 809 & 1 & 0 \\
\hline 2 HR AM & BUS & 2 & 0 & 1 & 3 & 4 & 3 & 0 & 0 & 0 & 0 & 2 & 0 & 2 & 0 & 2 & 11 & 0 & 11 & 1 & 12 & $\begin{array}{l}E \\
W\end{array}$ & $\begin{array}{l}1,494 \\
1,089\end{array}$ & $\begin{array}{r}0 \\
11\end{array}$ & $\begin{array}{l}0 \\
0\end{array}$ \\
\hline
\end{tabular}

\begin{tabular}{|c|c|c|c|c|c|c|c|c|c|c|c|c|c|c|c|c|c|c|c|c|c|c|c|c|c|}
\hline & TAL: & 861 & 24 & 596 & 403 & 1,023 & 543 & 0 & 0 & 0 & 0 & 479 & 140 & 391 & 96 & 627 & 665 & 88 & 545 & 265 & 898 & & & & \\
\hline \multirow{2}{*}{ 16:00-18:00 } & CAR & 1,225 & 73 & 709 & 53 & 835 & 92 & 0 & 0 & 0 & 0 & 953 & 39 & 664 & 224 & 927 & 1,627 & 289 & 1,330 & 516 & 2,135 & $\mathrm{~N}$ & 891 & 0 & 0 \\
\hline & TRK & 12 & 2 & 9 & 0 & 11 & 1 & 0 & 0 & 0 & 0 & 13 & 1 & 7 & 4 & 12 & 18 & 6 & 12 & 3 & 21 & $S$ & 509 & 0 & 0 \\
\hline 2 HR PM & BUS & 5 & 0 & 4 & 1 & 5 & 1 & 0 & 0 & 0 & 0 & 2 & 0 & 2 & 0 & 2 & 10 & 0 & 10 & 1 & 11 & $\begin{array}{l}E \\
W\end{array}$ & $\begin{array}{r}1,464 \\
653\end{array}$ & $\begin{array}{l}0 \\
0\end{array}$ & $\begin{array}{l}0 \\
0\end{array}$ \\
\hline
\end{tabular}

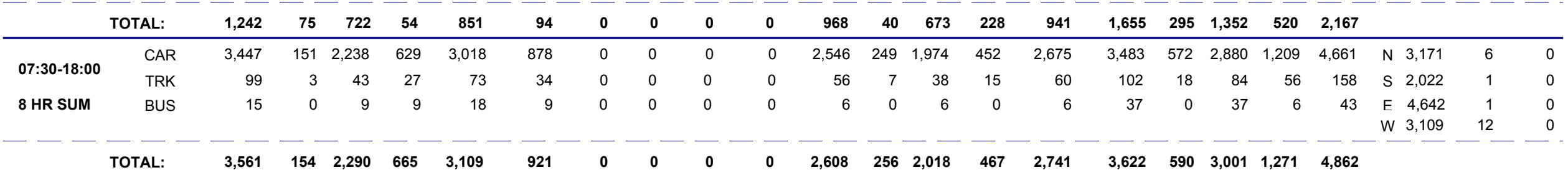

Total 8 Hour Vehicle Volume: 10,712

Total 8 Hour Bicycle Volume: 20

Total 8 Hour Intersection Volume: 10,732

Comment: THIRD PHASE RAMP RE-OPEN BAY ST CLOSURE TO FGG EB 


\section{Turning Movement Count Summary Report}

BLUE JAYS WAY AT WELLINGTON ST (PX 1682)

$$
\begin{array}{lll}
\text { Survey Date: } & \text { 2011-Jul-27 } & \text { (Wednesday) } \\
\text { Survey Type: } & \text { Routine Hours } &
\end{array}
$$

$\begin{array}{llll}\text { Time Vehicle NORTHBOUND SOUTHBOUND } & \text { EASTBOUND }\end{array}$

\begin{tabular}{|c|c|c|c|c|c|c|c|c|c|c|c|c|c|c|c|c|c|c|c|c|c|c|c|c|c|}
\hline & CAR & 705 & 13 & 603 & 0 & 616 & 0 & 24 & 0 & 32 & 56 & 445 & 0 & 313 & 21 & 334 & 95 & 100 & 61 & 78 & 239 & $N$ & 483 & 0 & 0 \\
\hline $08: 30-09: 30$ & TRK & 24 & 1 & 20 & 0 & 21 & 0 & 0 & 0 & 1 & 1 & 19 & 0 & 10 & 1 & 11 & 2 & 8 & 0 & 4 & 12 & $s$ & 975 & 0 & 0 \\
\hline AM PEAK & BUS & 2 & 0 & 2 & 0 & 2 & 0 & 0 & 0 & 0 & 0 & 6 & 0 & 5 & 0 & 5 & 0 & 1 & 0 & 0 & 1 & $\begin{array}{l}E \\
W\end{array}$ & $\begin{array}{l}334 \\
382\end{array}$ & $\begin{array}{l}0 \\
0\end{array}$ & $\begin{array}{l}0 \\
0\end{array}$ \\
\hline
\end{tabular}



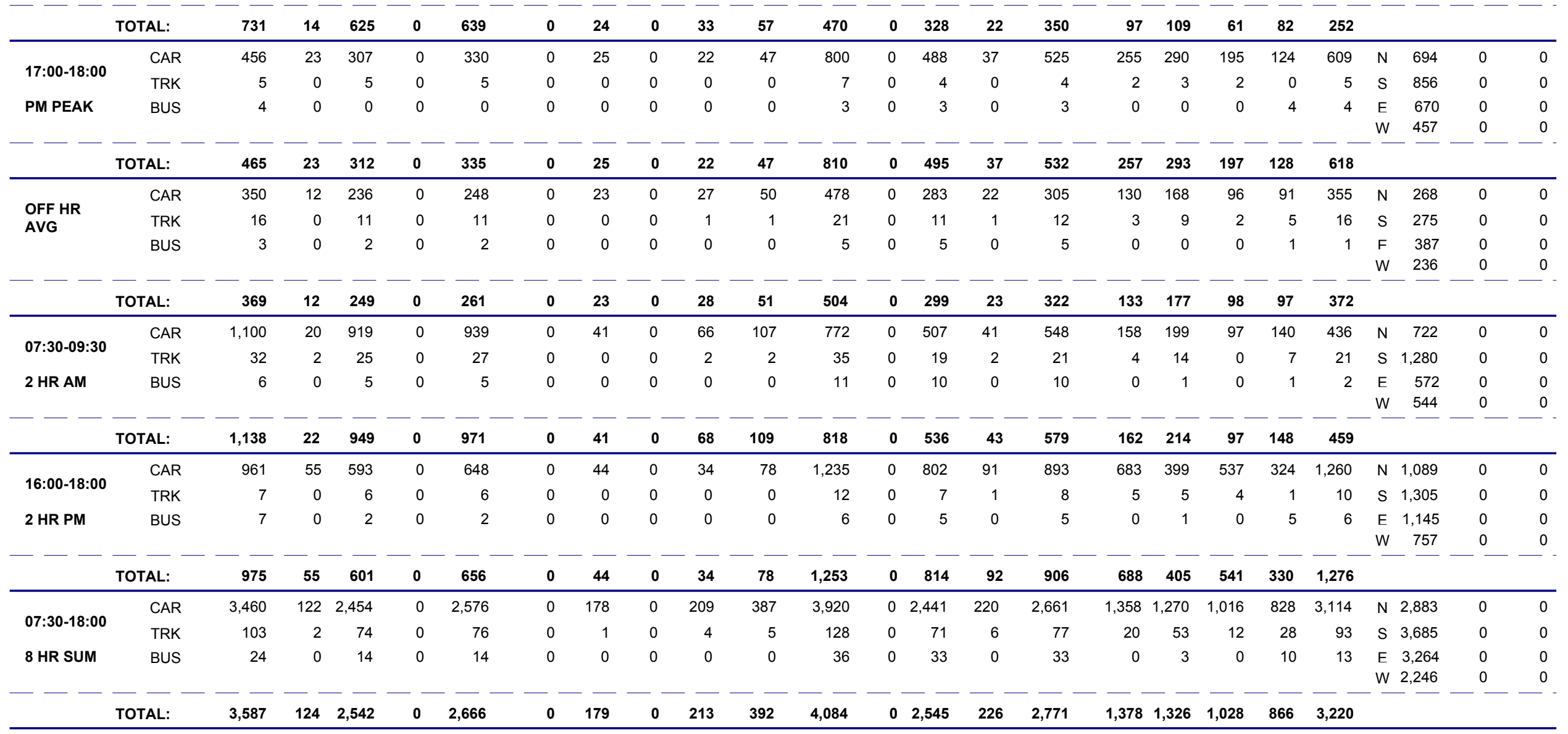




\section{APPENDIX B}

Signal Timing Plans 







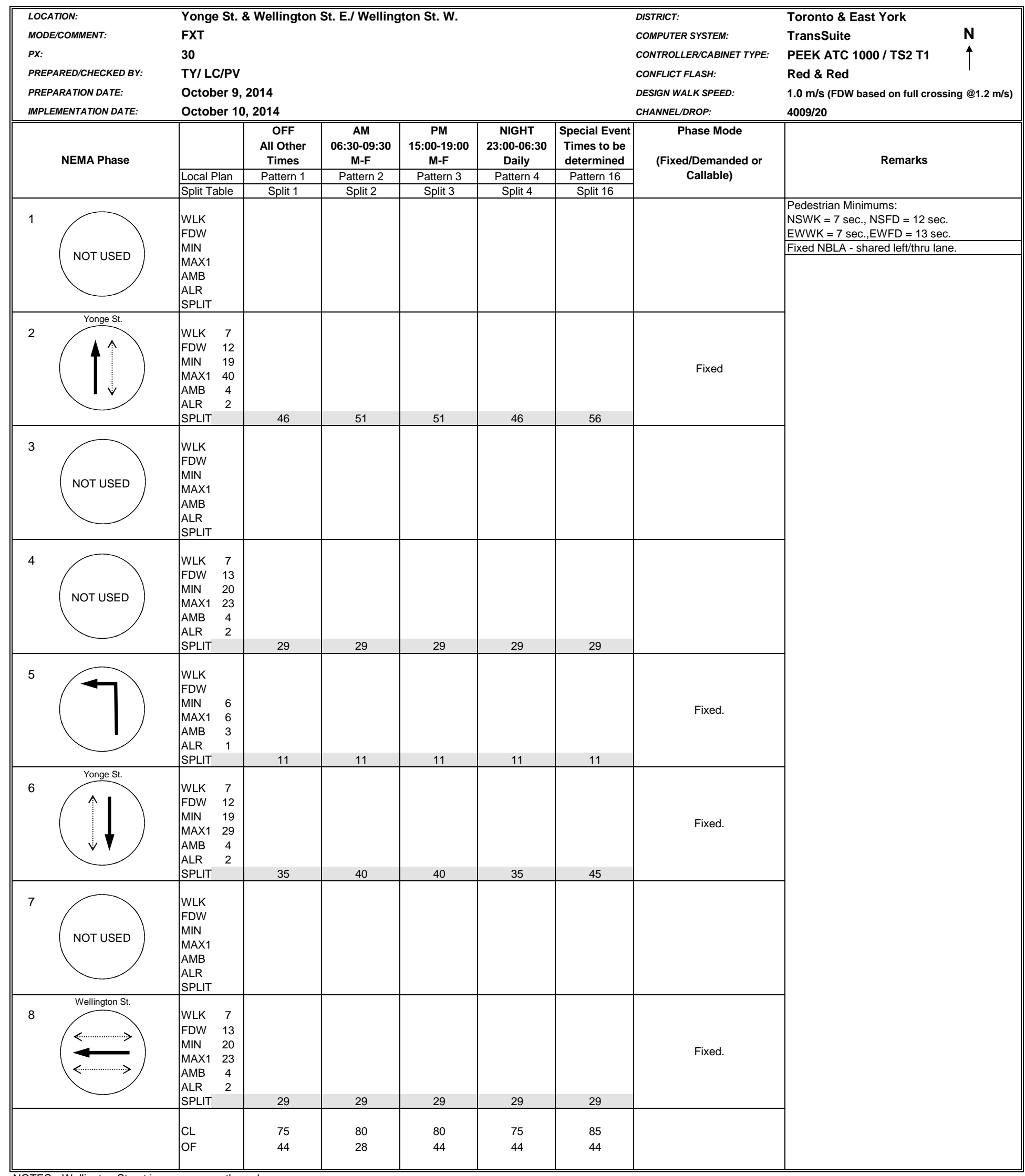

NOTES: Wellington Street is one-way westbound.

Picked up system control on January 28, 2014 


\begin{tabular}{|c|c|c|c|c|c|c|c|c|}
\hline $\begin{array}{l}\text { LOCATION: } \\
\text { PX: } \\
\text { MODE / COMMENT: } \\
\text { PREPARED / CHECKED BY: } \\
\text { PREPARATION DATE: } \\
\text { IMPLEMENTATION DATE: }\end{array}$ & $\begin{array}{l}\text { Bay St \& Wellin } \\
60 \\
\text { FXT with 2-wire } \\
\text { TS } \\
\text { February } 15,20 \\
\text { February } 15,20 \\
\end{array}$ & $\begin{array}{l}\text { Ion St } \\
2 \\
2 \\
2\end{array}$ & ( & 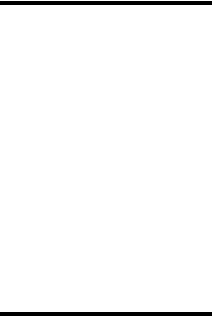 & 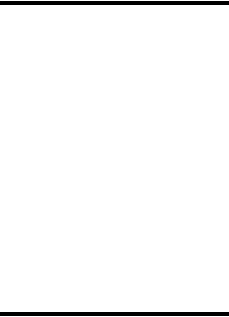 & 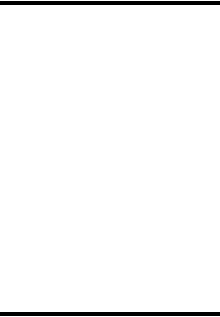 & $\begin{array}{r}\text { DISTRICT: } \\
\text { COMPUTER SYSTEM: } \\
\text { CONTROLLER/CABINET TYPE: } \\
\text { CONFLICT FLASH: } \\
\text { DESIGN WALK SPEED: } \\
\text { CHANNEL/DROP: }\end{array}$ & $\begin{array}{l}\text { Toronto \& East York } \\
\text { TransSuite } \\
\text { Econolite ASC/3-2100 / TS2 T1 } \\
\text { Red \& Red } \\
1.0 \mathrm{~m} / \mathrm{s} \text { (FDW based on full crossing @ } 1.2 \mathrm{~m} / \mathrm{s} \text { ) } \\
4016 / 2\end{array}$ \\
\hline NEMA Phase & \begin{tabular}{|l} 
Local Plan \\
System Plan \\
\end{tabular} & $\begin{array}{c}\text { OFF } \\
\begin{array}{c}\text { All Other } \\
\text { Times }\end{array} \\
\text { Pattern } 1 \\
\text { Plan } 1\end{array}$ & \begin{tabular}{|c|} 
AM \\
$\begin{array}{c}\text { 07:00-09:30 } \\
\text { M-F }\end{array}$ \\
Pattern 2 \\
Plan 2 \\
\end{tabular} & \begin{tabular}{|c|} 
PM \\
$\begin{array}{c}\text { 15:30-18:15 } \\
\text { M-F }\end{array}$ \\
Pattern 3 \\
Plan 3 \\
\end{tabular} & \begin{tabular}{|c|} 
PAM \\
06:45-7:00 M \\
F \\
Pattern 4 \\
Plan 4 \\
\end{tabular} & $\begin{array}{c}\text { Gardiner } \\
\begin{array}{c}\text { Times to be } \\
\text { determined }\end{array} \\
\text { Pattern } 61 \\
\text { Plan } 61 \\
\end{array}$ & $\begin{array}{c}\text { Phase Mode } \\
\text { (Fixed/Demanded/Callable) }\end{array}$ & Remarks \\
\hline 1 & $\begin{array}{l}\text { WLK } \\
\text { FDW } \\
\text { MIN } \\
\text { MAX1 } \\
\text { AMB } \\
\text { ALR } \\
\text { SPLIT } \\
\end{array}$ & & & & & & & \begin{tabular}{|l} 
Pedestrian Minimums: \\
NSWK $=7$ sec., NSFD $=12$ sec. \\
EWWK $=7$ sec., EWFD $=12$ sec. \\
APS on during NSWK and EWWK when activated. \\
APS not on during NBLA. \\
Extended Push Activation $=3$ sec. \\
NS pushbutton monitored on local detector $2 \&$ \\
EW pushbutton monitored on local detector 6. \\
\end{tabular} \\
\hline 2 & \begin{tabular}{|lc} 
WLK & 7 \\
FDW & 12 \\
MIN & 19 \\
MAX1 & 19 \\
AMB & 4 \\
ALR & 3 \\
SPLIT & \\
\end{tabular} & 33 & $\begin{array}{l}20 \\
27 \\
43\end{array}$ & 36 & 37 & 43 & Fixed & ( \\
\hline 3 & $\begin{array}{l}\text { WLK } \\
\text { FDW } \\
\text { MIN } \\
\text { MAX1 } \\
\text { AMB } \\
\text { ALR } \\
\text { SPLIT }\end{array}$ & & & & & & & \\
\hline 4 & \begin{tabular}{|lc} 
WLK & 7 \\
FDW & 12 \\
MIN & 19 \\
MAX1 & 19 \\
AMB & 4 \\
ALR & 2 \\
SPLIT &
\end{tabular} & 27 & 27 & 34 & 33 & 27 & & 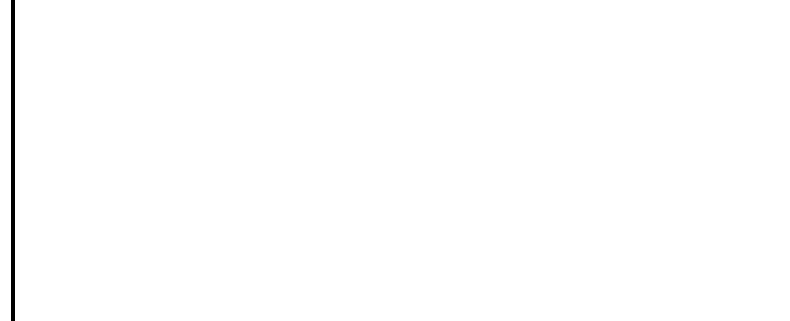 \\
\hline 5 & $\begin{array}{l}\text { WLK } \\
\text { FDW } \\
\text { MIN } \\
\text { MAX1 } \\
\text { AMB } \\
\text { ALR } \\
\text { SPLIT }\end{array}$ & & 12 & & & & $\begin{array}{c}\text { Fixed NBLA } \\
\text { 7:00-9:30 M-F } \\
\text { (in shared left/thru lane) }\end{array}$ & \\
\hline 6 & \begin{tabular}{|lc} 
WLK & 7 \\
FDW & 12 \\
MIN & 19 \\
MAX1 & 19 \\
AMB & 4 \\
ALR & 3 \\
SPLIT &
\end{tabular} & 33 & 31 & 36 & 37 & 43 & Fixed & $\mathrm{C}_{\mathrm{C}} \mathrm{C}$ \\
\hline 7 & $\begin{array}{l}\text { WLK } \\
\text { FDW } \\
\text { MIN } \\
\text { MAX1 } \\
\text { AMB } \\
\text { ALR } \\
\text { SPLIT }\end{array}$ & & & & & & & \\
\hline 8 Wellington St & \begin{tabular}{|lc} 
WLK & 7 \\
FDW & 12 \\
MIN & 19 \\
MAX1 & 19 \\
AMB & 4 \\
ALR & 2 \\
SPLIT &
\end{tabular} & 27 & 27 & 34 & 33 & 27 & Fixed & ( \\
\hline & $\begin{array}{l}\mathrm{CL} \\
\mathrm{OF}\end{array}$ & $\begin{array}{l}60 \\
35\end{array}$ & $\begin{array}{l}70 \\
47\end{array}$ & $\begin{array}{l}70 \\
15\end{array}$ & $\begin{array}{l}70 \\
37\end{array}$ & $\begin{array}{c}70 \\
1\end{array}$ & & \\
\hline
\end{tabular}

Pick up on TransSuite system on Mar 5,2013. 


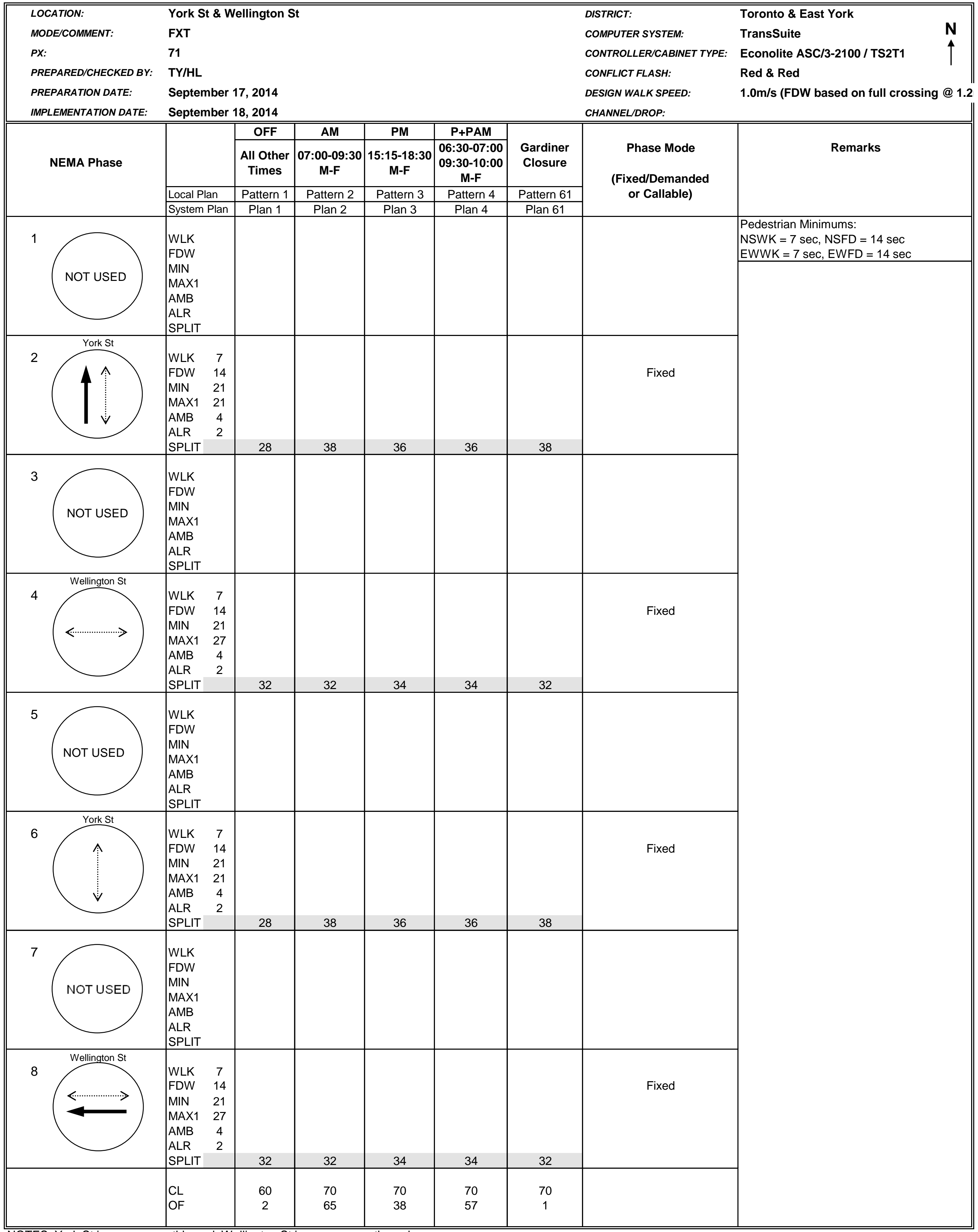




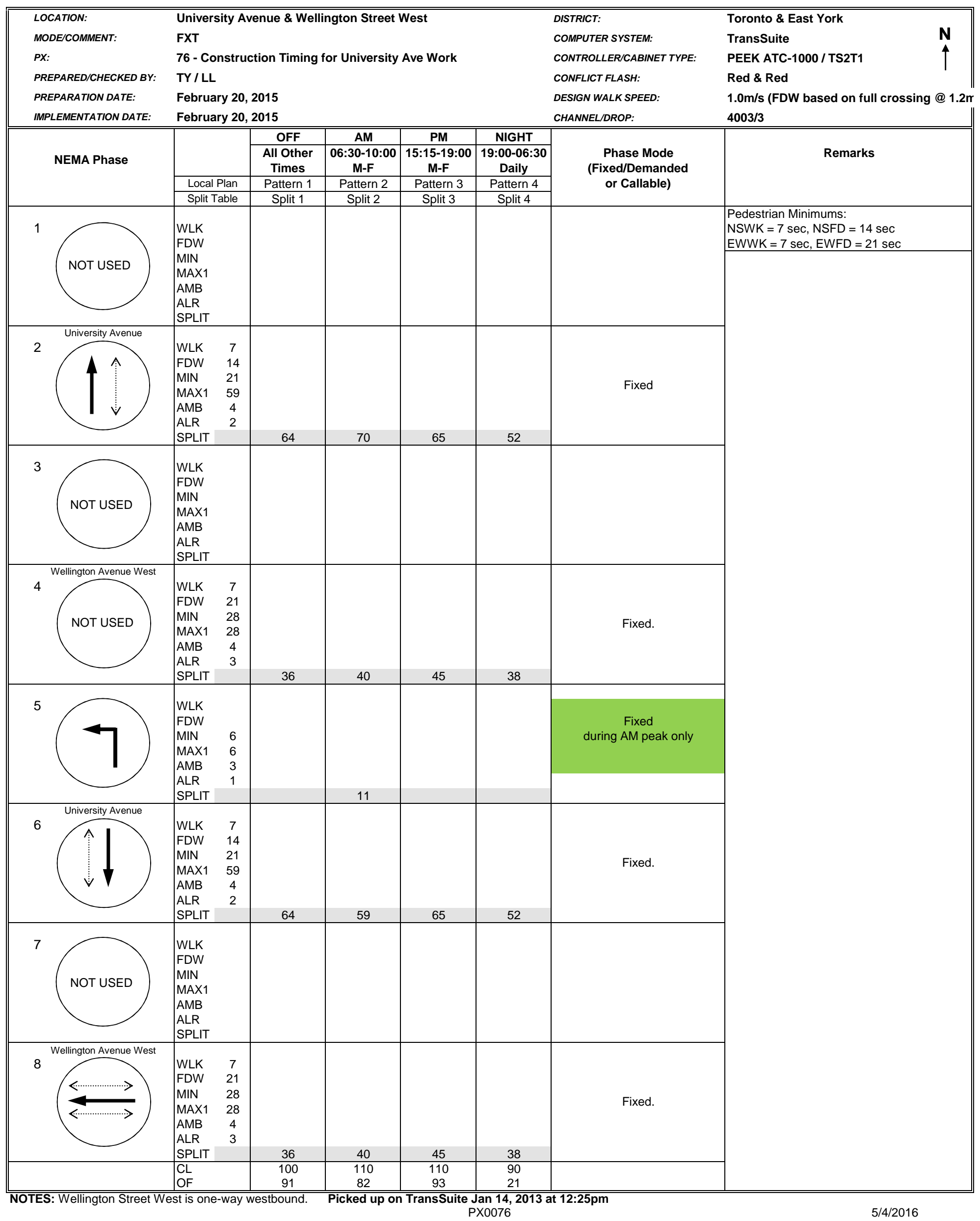









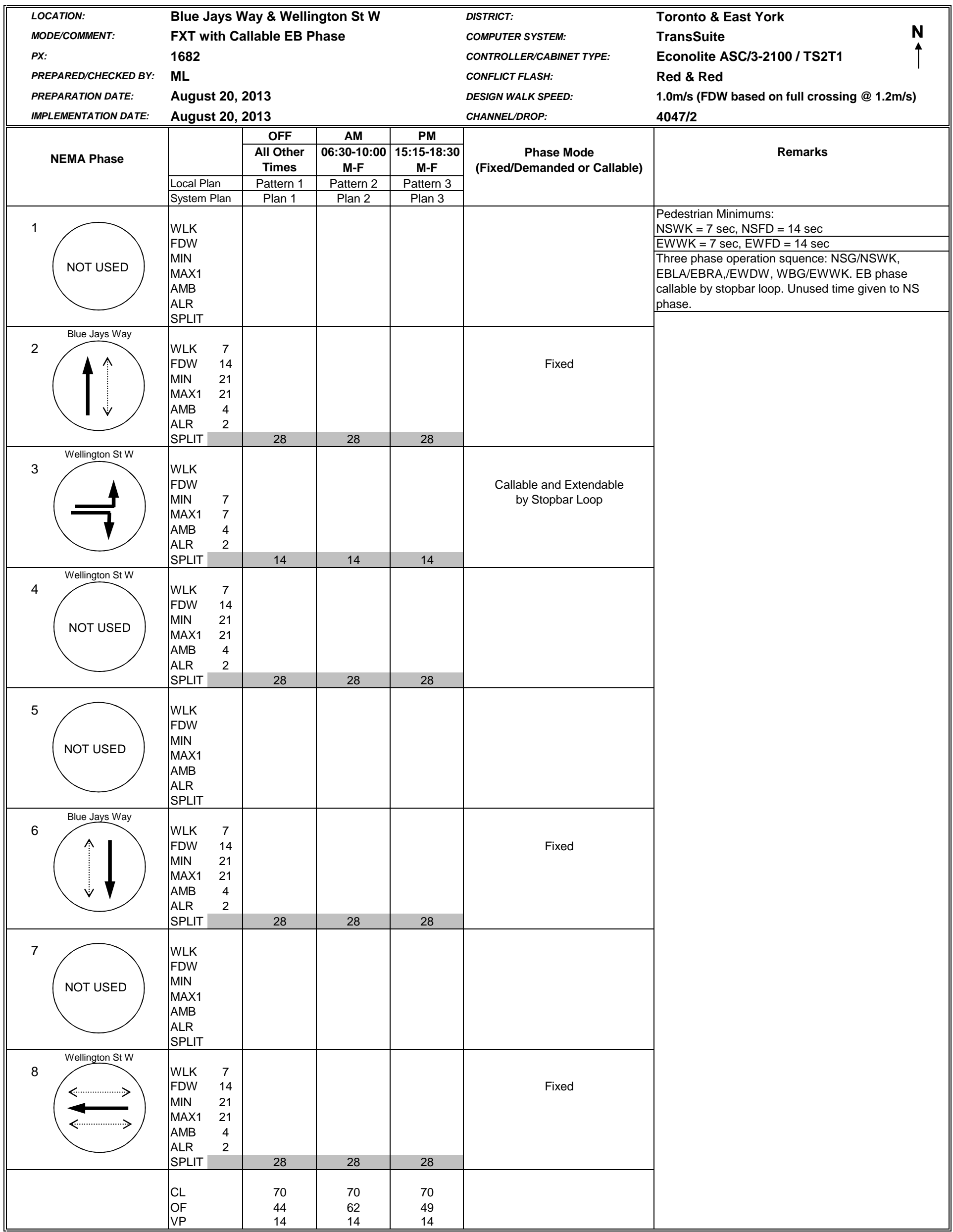




\section{APPENDIX C}

Field Observation 


\section{Field Observations (Before Study) - WELLINGTON WEST}

Church Street

\section{AM Peak}

- Free flow between Church and Yonge

- Lane reduction due to on street parking on north side

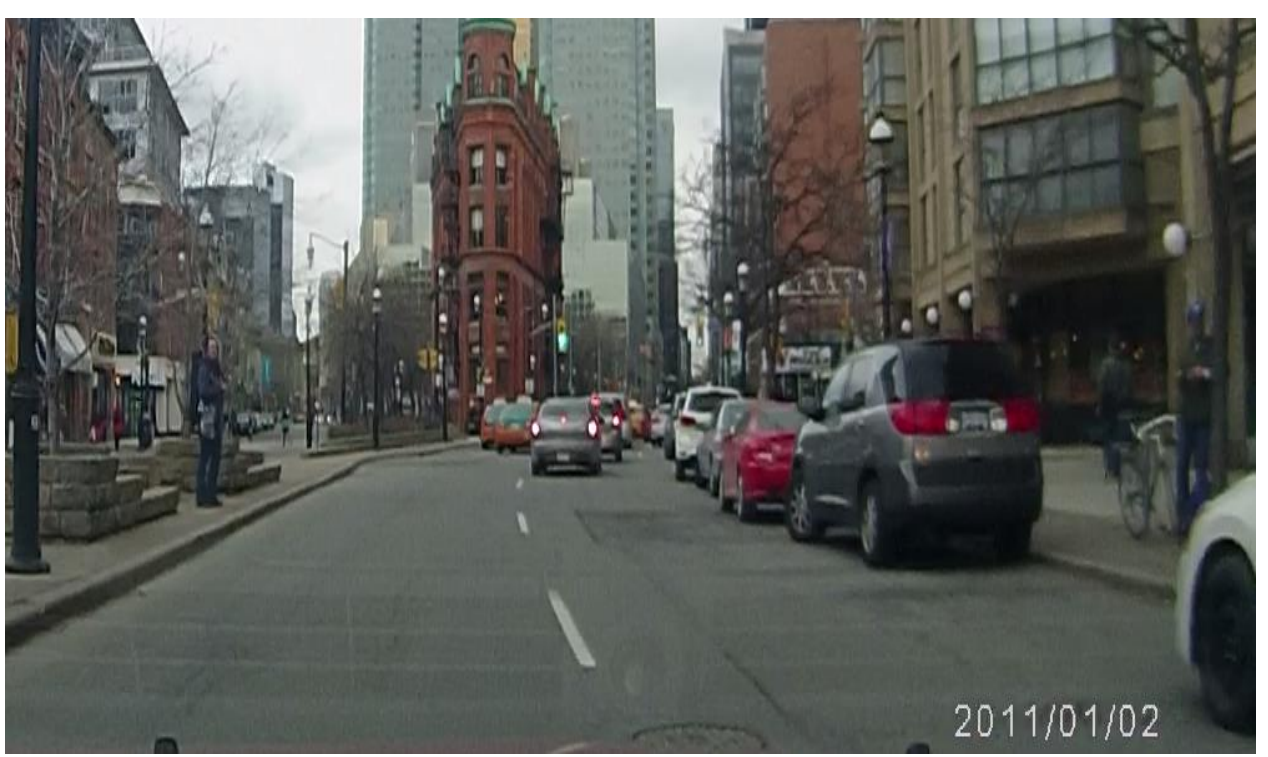

Yonge Street

AM Peak

- Lane reduction due to construction

- Free Flow

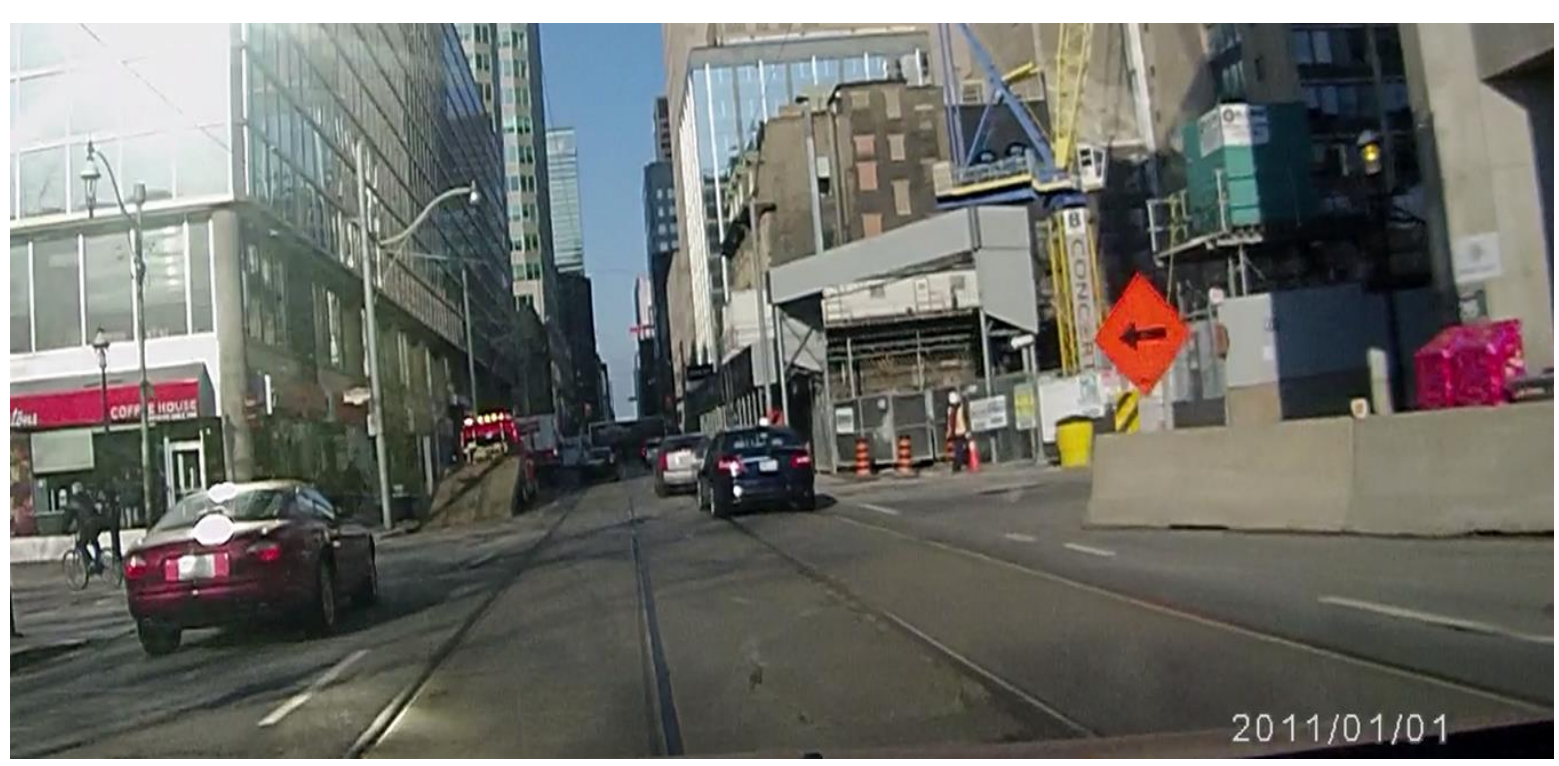


Yonge Street

PM Peak

- On-street parking on both sides resulting in reduced number of lane

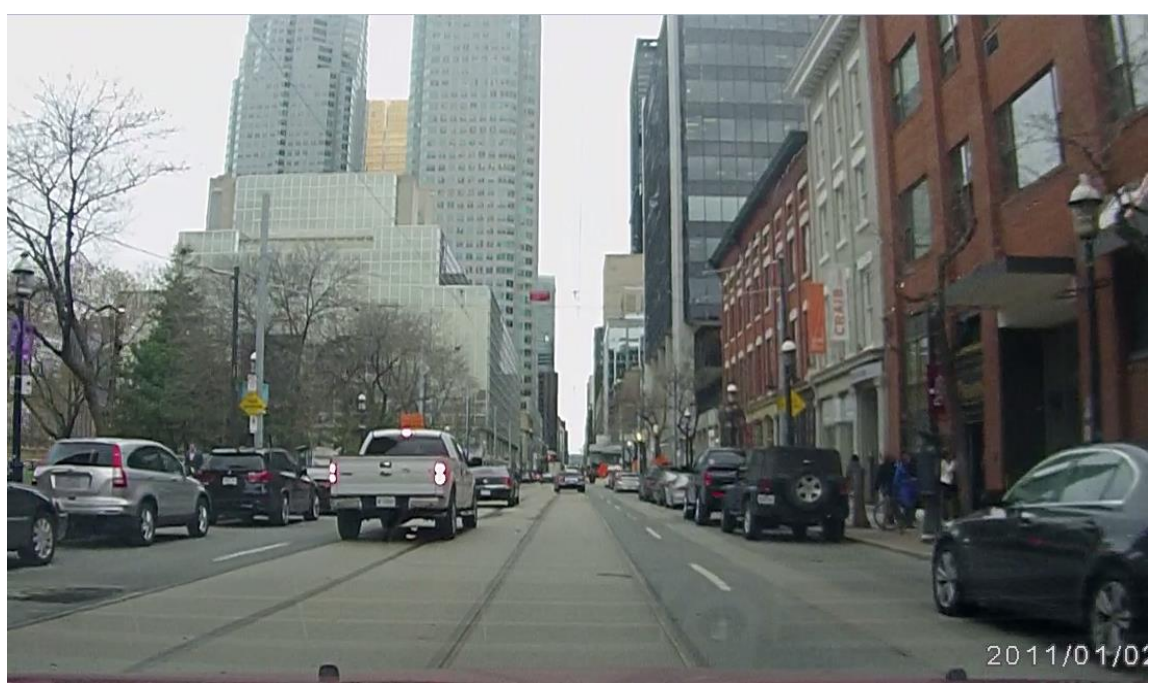

\section{Bay Street}

PM Peak

- Light traffic congestion

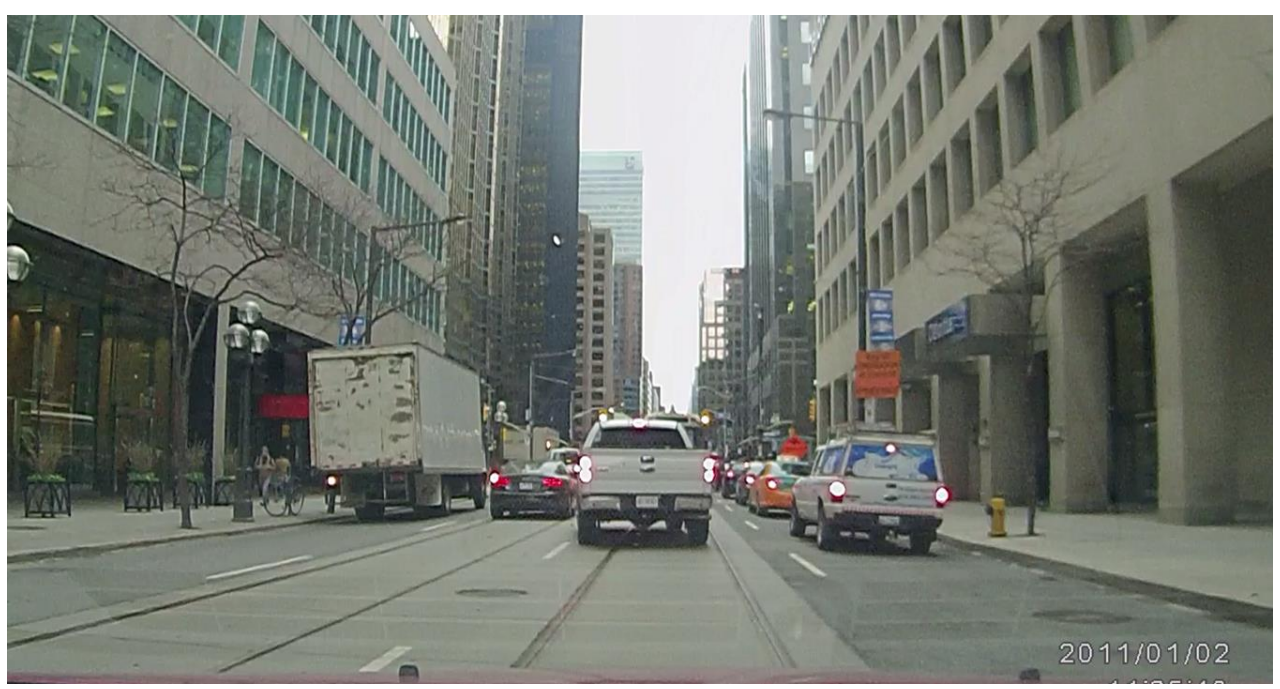


$\underline{\text { York Street }}$

\section{AM Peak}

- Free flow between Bay and York, However street parking for Taxies reduces the lanes number to two

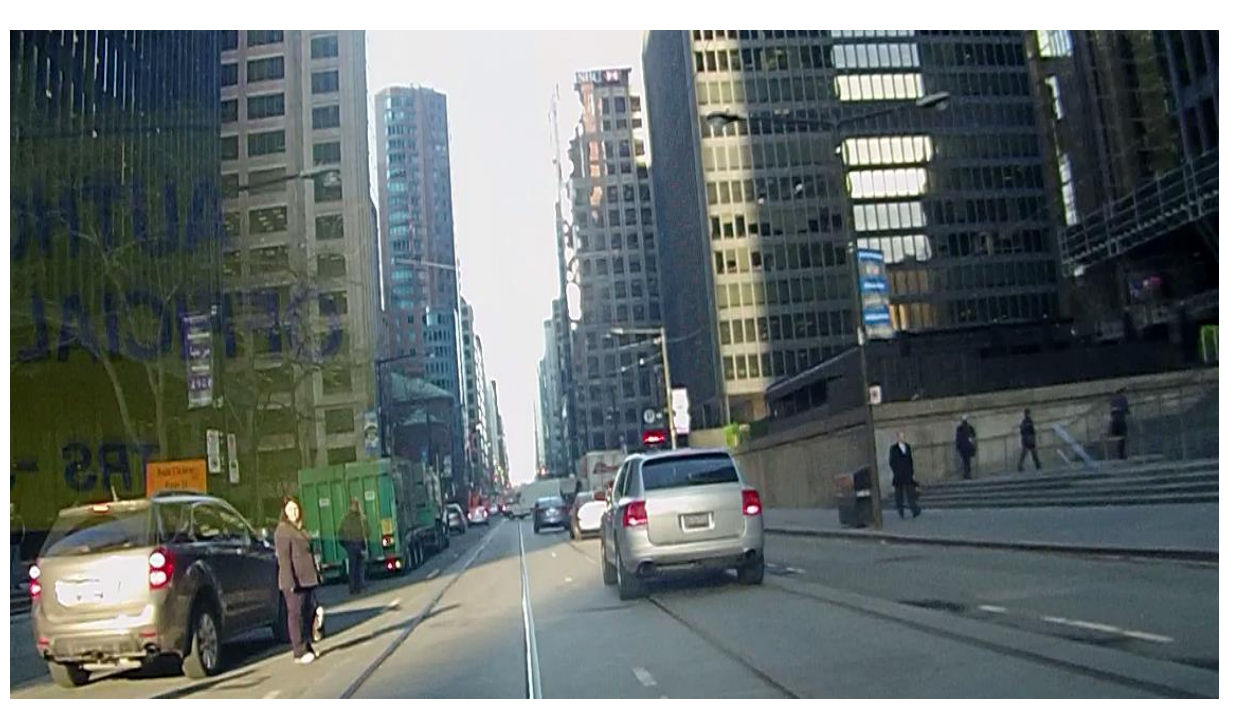

\section{York Street}

PM Peak

- Moderate congestion on through movement with heavier left turn lane.

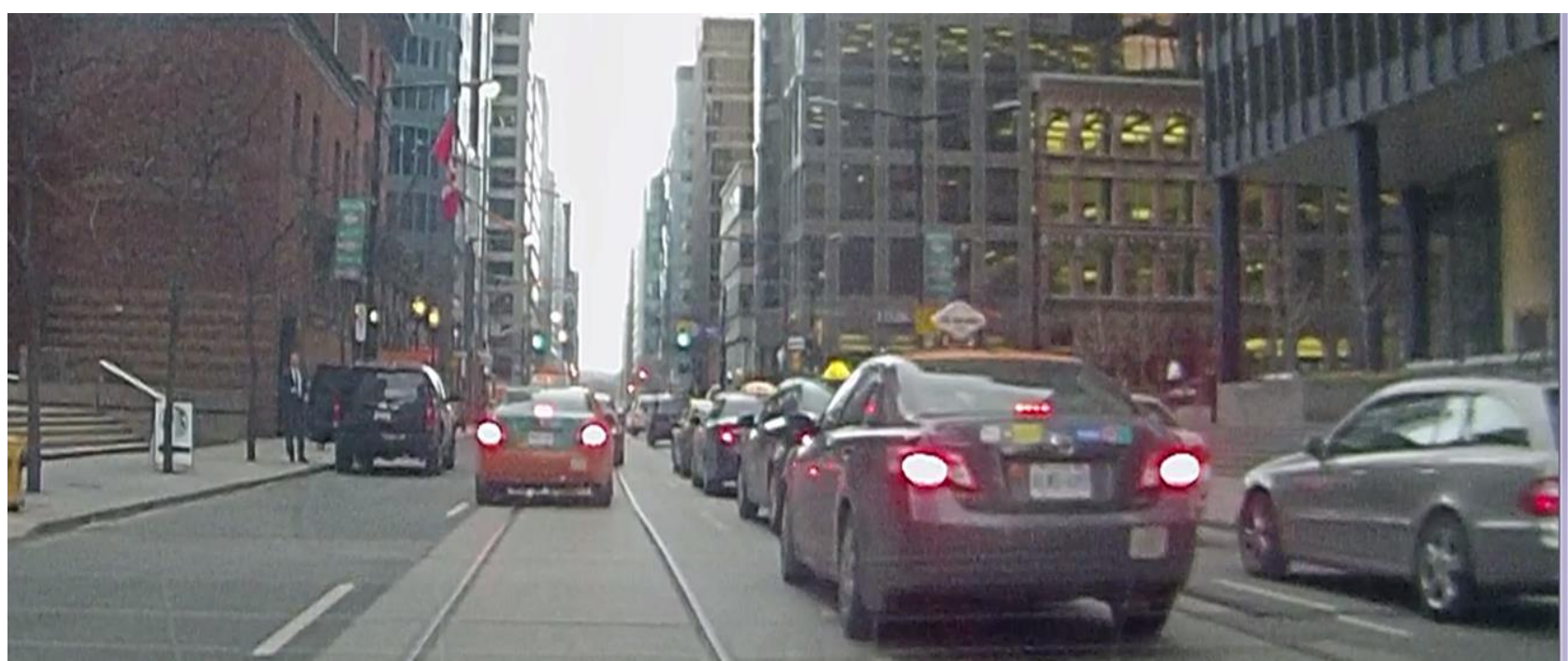


University Street

\section{AM Peak}

- Long left turn queue requires two cycle to clear

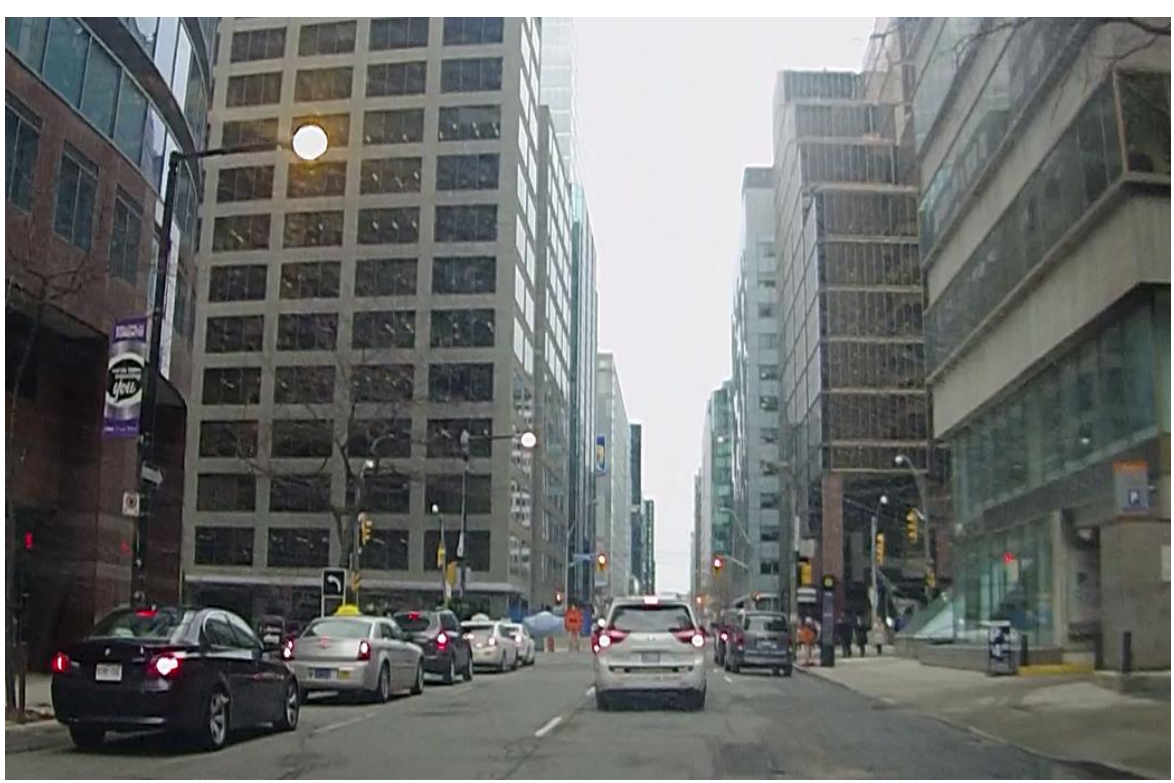

York Street

\section{PM Peak}

- Moderate congestion

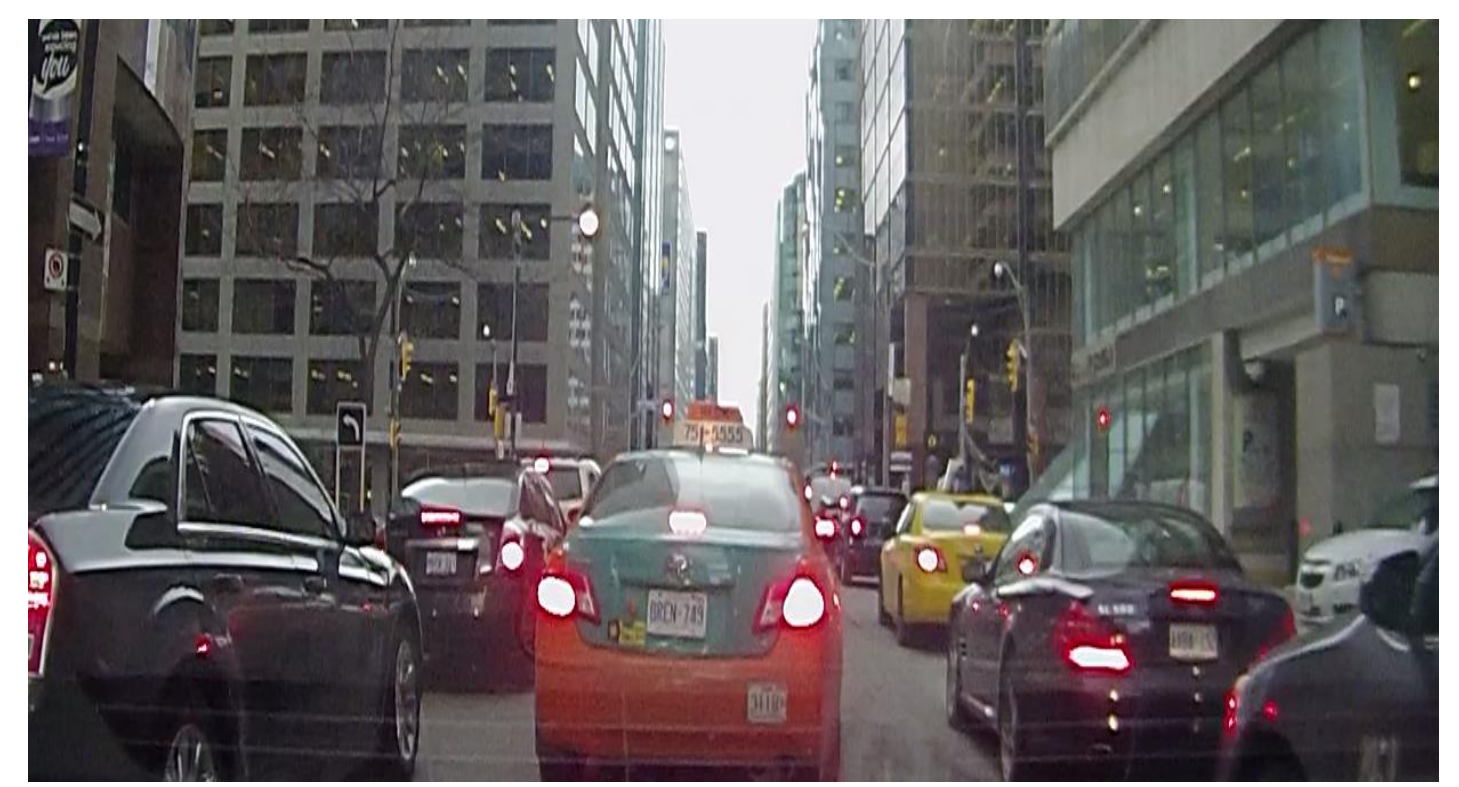




\section{APPENDIX D}

Before Speed and Travel Run Studies 


\section{City of Toronto}

Heading Second Line

Heading Third Line

Overall Output Statistics

Study Name : wellington street AM

Study Date : 04/24/2015

Page No. : : 1

\begin{tabular}{|c|c|l|c|c|c|c|c|c|c|}
\hline $\begin{array}{c}\text { Node } \\
\#\end{array}$ & Length & \multicolumn{1}{|c|}{ Node } & $\begin{array}{c}\text { Travel } \\
\text { Time }\end{array}$ & $\begin{array}{c}\text { \# of } \\
\text { Stops }\end{array}$ & $\begin{array}{c}\text { Avg } \\
\text { Speed }\end{array}$ & $\begin{array}{c}\text { Total } \\
\text { Delay }\end{array}$ & $\begin{array}{c}\text { Time }<= \\
\mathbf{1 0} \mathbf{K P H}\end{array}$ & $\begin{array}{c}\text { Time }<= \\
\mathbf{5 0} \mathbf{K P H}\end{array}$ & $\begin{array}{c}\text { Time }<= \\
\mathbf{7 0} \mathbf{K P H}\end{array}$ \\
\hline 1 & 0 & & & & & & & & \\
2 & 193 & CHURCH & 52.5 & 0.7 & 13.2 & 40.5 & 26.5 & 52.5 & 52.5 \\
3 & 289 & YONGE & 85.7 & 1.7 & 12.1 & 68.5 & 47.5 & 85.7 & 85.7 \\
4 & 202 & BAY & 64.3 & 0.8 & 11.3 & 52.3 & 36.7 & 64.3 & 64.3 \\
5 & 285 & YORK & 47.3 & 1.0 & 21.7 & 30.3 & 11.3 & 47.3 & 47.3 \\
6 & 40 & UNIVERSITY & 17.8 & 0.3 & 8.1 & 15.3 & 12.0 & 17.8 & 17.8 \\
7 & 97 & SIMCOE & 28.3 & 0.5 & 12.4 & 22.2 & 16.7 & 27.5 & 28.3 \\
8 & 288 & JOHN & 50.8 & 0.8 & 20.4 & 33.3 & 19.7 & 50.7 & 50.8 \\
9 & 217 & BLUE JAYS WAY & 30.3 & 0.3 & 25.8 & 17.2 & 11.0 & 29.2 & 30.2 \\
10 & 62 & & 4.8 & 0.0 & 46.3 & 1.5 & 0.0 & 4.0 & 4.7 \\
\hline Total & $\mathbf{1 , 6 7 3}$ & & $\mathbf{3 8 2 . 0}$ & $\mathbf{6 . 2}$ & $\mathbf{1 5 . 8}$ & $\mathbf{2 8 1 . 2}$ & $\mathbf{1 8 1 . 3}$ & $\mathbf{3 7 9 . 0}$ & $\mathbf{3 8 1 . 7}$ \\
\hline
\end{tabular}

Stats based on 6 BEFORE runs.

Stops based on a Stop Speed of $8 \mathrm{KPH}$.

Total Delay based on a Normal Speed of $60 \mathrm{KPH}$. 


\section{City of Toronto}

Heading Second Line

Heading Third Line

Detailed Statistics By Run

Study Name : wellington street AM

Study Date : 04/24/2015

Page No. : : 2

Travel Time (sec) by Section

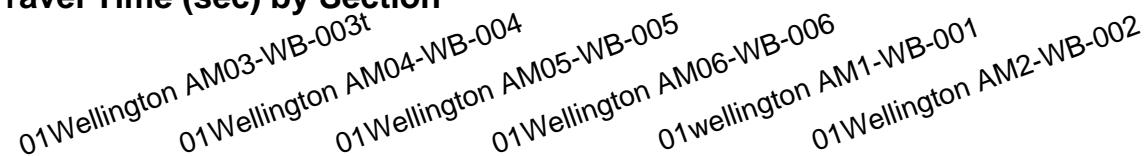

\begin{tabular}{|c|c|l|c|c|c|c|c|c|}
\hline $\begin{array}{c}\text { Node } \\
\text { \# }\end{array}$ & Length & \multicolumn{1}{|c|}{ Node Name } & Run \#1 & Run \#2 & Run \#3 & Run \#4 & Run \#5 & Run \#6 \\
\hline 1 & 0 & & & & & & & \\
2 & 193 & CHURCH & 27 & 52 & 78 & 64 & 73 & 21 \\
3 & 289 & YONGE & 106 & 65 & 97 & 91 & 32 & 123 \\
4 & 202 & BAY & 84 & 20 & 76 & 41 & 105 & 60 \\
5 & 285 & YORK & 57 & 27 & 78 & 36 & 29 & 57 \\
6 & 40 & UNIVERSITY & 68 & 15 & 6 & 7 & 6 & 5 \\
7 & 97 & SIMCOE & 10 & 36 & 26 & 54 & 36 & 8 \\
8 & 288 & JOHN & 22 & 77 & 29 & 49 & 67 & 61 \\
9 & 217 & BLUE JAYS WAY & 59 & 50 & 17 & 18 & 19 & 19 \\
10 & 62 & & 9 & 5 & 5 & 6 & 4 & 0 \\
\hline Totals & $\mathbf{1 6 7 3}$ & & $\mathbf{4 4 2}$ & $\mathbf{3 4 7}$ & $\mathbf{4 1 2}$ & $\mathbf{3 6 6}$ & $\mathbf{3 7 1}$ & $\mathbf{3 5 4}$ \\
\hline
\end{tabular}




\section{City of Toronto}

Heading Second Line

Heading Third Line

Detailed Statistics By Run
Study Name : wellington street AM

Study Date : 04/24/2015

Page No. : 3

\section{Number of Stops by Section}

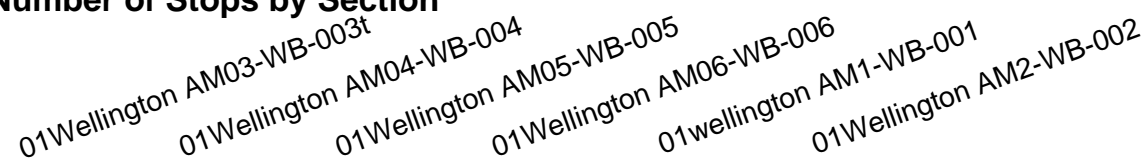

\begin{tabular}{|c|c|l|c|c|c|c|c|c|}
\hline $\begin{array}{c}\text { Node } \\
\text { \# }\end{array}$ & Length & \multicolumn{1}{|c|}{ Node Name } & Run \#1 & Run \#2 & Run \#3 & Run \#4 & Run \#5 & Run \#6 \\
\hline 1 & 0 & & & & & & & \\
2 & 193 & CHURCH & 0 & 1 & 1 & 1 & 1 & 0 \\
3 & 289 & YONGE & 2 & 1 & 1 & 2 & 1 & 3 \\
4 & 202 & BAY & 1 & 0 & 1 & 1 & 1 & 1 \\
5 & 285 & YORK & 1 & 0 & 1 & 1 & 0 & 3 \\
6 & 40 & UNIVERSITY & 0 & 0 & 1 & 1 & 1 & 0 \\
7 & 97 & SIMCOE & 0 & 2 & 0 & 1 & 1 & 1 \\
8 & 288 & JOHN & 1 & 1 & 0 & 0 & 0 & 0 \\
9 & 217 & BLUE JAYS WAY & 0 & 0 & 0 & 0 & 0 & 0 \\
10 & 62 & & $\mathbf{6}$ & $\mathbf{6}$ & $\mathbf{5}$ & $\mathbf{7}$ & $\mathbf{5}$ & $\mathbf{8}$ \\
\hline Totals & $\mathbf{1 6 7 3}$ & & & & & & 0 \\
\hline
\end{tabular}

Stops based on a Stop Speed of $8 \mathrm{KPH}$. 
City of Toronto

Heading Second Line

Heading Third Line

Detailed Statistics By Run

Study Name : wellington street AM

Study Date : 04/24/2015

Page No. : $\mathbf{4}$

\section{Average Speed (KPH) by Section}

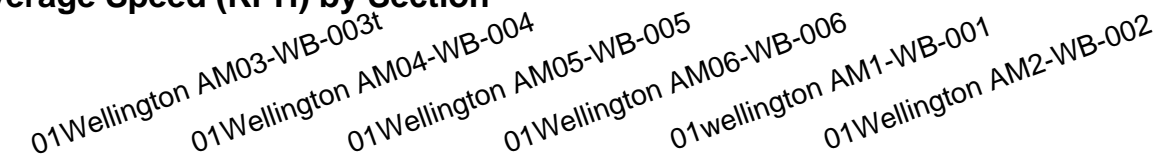

\begin{tabular}{|c|c|l|c|c|c|c|c|c|}
\hline $\begin{array}{c}\text { Node } \\
\text { \# }\end{array}$ & Length & \multicolumn{1}{|c|}{ Node Name } & Run \#1 & Run \#2 & Run \#3 & Run \#4 & Run \#5 & Run \#6 \\
\hline 1 & 0 & & & & & & & \\
2 & 193 & CHURCH & 25.6 & 13.6 & 9.2 & 11.2 & 9.9 & 34.0 \\
3 & 289 & YONGE & 9.8 & 15.8 & 10.7 & 11.2 & 31.5 & 8.4 \\
4 & 202 & BAY & 8.7 & 36.5 & 9.6 & 17.9 & 7.0 & 12.1 \\
5 & 285 & YORK & 17.8 & 38.3 & 13.1 & 28.6 & 34.9 & 18.0 \\
6 & 40 & UNIVERSITY & 2.2 & 8.7 & 25.2 & 19.5 & 24.9 & 33.1 \\
7 & 97 & SIMCOE & 39.6 & 9.8 & 13.6 & 6.9 & 9.6 & 40.6 \\
8 & 288 & JOHN & 47.0 & 13.8 & 35.1 & 20.7 & 15.5 & 17.3 \\
9 & 217 & BLUE JAYS WAY & 13.0 & 15.7 & 46.4 & 45.1 & 41.7 & 37.0 \\
10 & 62 & & 24.9 & 42.5 & 45.1 & 35.9 & 63.6 & 0.0 \\
\hline Totals & $\mathbf{1 6 7 3}$ & & $\mathbf{1 3 . 7}$ & $\mathbf{1 7 . 4}$ & $\mathbf{1 4 . 7}$ & $\mathbf{1 6 . 5}$ & $\mathbf{1 6 . 3}$ & $\mathbf{1 6 . 2}$ \\
\hline
\end{tabular}


City of Toronto

Heading Second Line

Heading Third Line

Detailed Statistics By Run

Study Name : wellington street AM

Study Date : 04/24/2015

Page No. : 5

Total Delay (sec) by Section

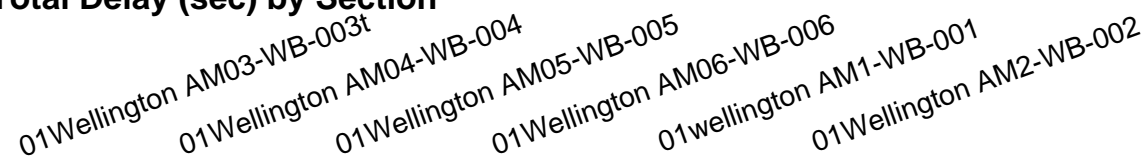

\begin{tabular}{|c|c|l|c|c|c|c|c|c|}
\hline $\begin{array}{c}\text { Node } \\
\text { \# }\end{array}$ & Length & \multicolumn{1}{|c|}{ Node Name } & Run \#1 & Run \#2 & Run \#3 & Run \#4 & Run \#5 & Run \#6 \\
\hline 1 & 0 & & & & & & & \\
2 & 193 & CHURCH & 15 & 40 & 66 & 52 & 61 & 9 \\
3 & 289 & YONGE & 89 & 48 & 79 & 74 & 15 & 106 \\
4 & 202 & BAY & 72 & 8 & 64 & 29 & 93 & 48 \\
5 & 285 & YORK & 40 & 10 & 61 & 19 & 12 & 40 \\
6 & 40 & UNIVERSITY & 66 & 13 & 3 & 4 & 4 & 2 \\
7 & 97 & SIMCOE & 3 & 30 & 20 & 48 & 30 & 2 \\
8 & 288 & JOHN & 4 & 59 & 12 & 32 & 50 & 43 \\
9 & 217 & BLUE JAYS WAY & 46 & 36 & 4 & 4 & 6 & 7 \\
10 & 62 & & 5 & 1 & 1 & 2 & 0 & 0 \\
\hline Totals & $\mathbf{1 6 7 3}$ & & $\mathbf{3 4 0}$ & $\mathbf{2 4 5}$ & $\mathbf{3 1 0}$ & $\mathbf{2 6 4}$ & $\mathbf{2 7 1}$ & $\mathbf{2 5 7}$ \\
\hline
\end{tabular}

Total Delay based on a Normal Speed of $60 \mathrm{KPH}$. 


\section{City of Toronto}

Heading Second Line

Heading Third Line

Overall Output Statistics

Study Name : wellington pm

Study Date : 04/27/2015

Page No. : : 1

\begin{tabular}{|c|c|l|c|c|c|c|c|c|c|}
\hline $\begin{array}{c}\text { Node } \\
\#\end{array}$ & Length & Node & $\begin{array}{c}\text { Travel } \\
\text { Time }\end{array}$ & $\begin{array}{c}\text { \# of } \\
\text { Stops }\end{array}$ & $\begin{array}{c}\text { Avg } \\
\text { Speed }\end{array}$ & $\begin{array}{c}\text { Total } \\
\text { Delay }\end{array}$ & $\begin{array}{c}\text { Time }<= \\
\mathbf{1 0} \mathbf{K P H}\end{array}$ & $\begin{array}{c}\text { Time }<= \\
\mathbf{5 0} \mathbf{K P H}\end{array}$ & $\begin{array}{c}\text { Time }<= \\
\mathbf{7 0} \mathbf{K P H}\end{array}$ \\
\hline 1 & 0 & & & & & & & & \\
2 & 171 & church & 76.0 & 1.3 & 8.1 & 65.5 & 54.8 & 76.0 & 76.0 \\
3 & 303 & Yonge & 59.0 & 1.0 & 18.5 & 40.8 & 27.8 & 59.0 & 59.0 \\
4 & 193 & Bay & 45.3 & 1.0 & 15.3 & 33.3 & 20.5 & 45.3 & 45.3 \\
5 & 254 & York & 88.8 & 2.3 & 10.3 & 73.3 & 51.8 & 88.8 & 88.8 \\
6 & 77 & university & 32.8 & 0.5 & 8.4 & 27.8 & 22.5 & 32.8 & 32.8 \\
7 & 108 & Simcoe & 16.8 & 0.3 & 23.3 & 9.8 & 4.8 & 16.5 & 16.8 \\
8 & 277 & John & 42.5 & 0.5 & 23.4 & 25.5 & 13.3 & 42.3 & 42.5 \\
9 & 210 & Blue Jays way & 43.5 & 1.0 & 17.4 & 31.5 & 22.3 & 42.5 & 43.3 \\
10 & 45 & & 5.8 & 0.0 & 28.2 & 3.5 & 0.0 & 5.5 & 5.5 \\
\hline Total & $\mathbf{1 , 6 3 8}$ & & $\mathbf{4 1 0 . 3}$ & $\mathbf{7 . 8}$ & $\mathbf{1 4 . 4}$ & $\mathbf{3 1 0 . 8}$ & $\mathbf{2 1 7 . 5}$ & $\mathbf{4 0 8 . 5}$ & $\mathbf{4 0 9 . 8}$ \\
\hline
\end{tabular}

Stats based on 4 BEFORE runs.

Stops based on a Stop Speed of $8 \mathrm{KPH}$.

Total Delay based on a Normal Speed of $60 \mathrm{KPH}$. 


\section{City of Toronto}

Heading Second Line

Heading Third Line

Travel Time (sec) by Section

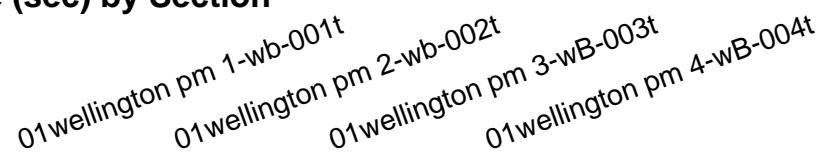

\begin{tabular}{|c|c|l|c|c|c|c|}
\hline $\begin{array}{c}\text { Node } \\
\text { \# }\end{array}$ & Length & \multicolumn{1}{|c|}{ Node Name } & Run \#1 & Run \#2 & Run \#3 & Run \#4 \\
\hline 1 & 0 & & & & & \\
2 & 171 & church & 97 & 74 & 66 & 67 \\
3 & 303 & Yonge & 25 & 49 & 76 & 86 \\
4 & 193 & Bay & 51 & 56 & 41 & 33 \\
5 & 254 & York & 29 & 41 & 90 & 195 \\
6 & 77 & university & 11 & 8 & 66 & 46 \\
7 & 108 & Simcoe & 14 & 9 & 34 & 10 \\
8 & 277 & John & 31 & 47 & 67 & 25 \\
9 & 210 & Blue Jays way & 51 & 58 & 41 & 24 \\
10 & 45 & & 6 & 8 & 9 & 0 \\
\hline Totals & $\mathbf{1 6 3 8}$ & & $\mathbf{3 1 5}$ & $\mathbf{3 5 0}$ & $\mathbf{4 9 0}$ & $\mathbf{4 8 6}$ \\
\hline
\end{tabular}




\section{City of Toronto}

Heading Second Line

Heading Third Line

Detailed Statistics By Run
Study Name : wellington pm

Study Date : 04/27/2015

Page No. : : 3

Number of Stops by Section

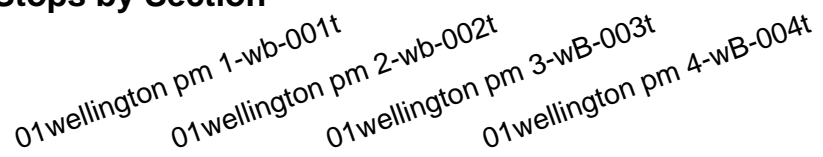

\begin{tabular}{|c|c|l|c|c|c|c|}
\hline $\begin{array}{c}\text { Node } \\
\#\end{array}$ & Length & \multicolumn{1}{|c|}{ Node Name } & Run \#1 & Run \#2 & Run \#3 & Run \#4 \\
\hline 1 & 0 & & & & & \\
2 & 171 & church & 2 & 1 & 1 & 1 \\
3 & 303 & Yonge & 0 & 1 & 2 & 1 \\
4 & 193 & Bay & 1 & 1 & 1 & 1 \\
5 & 254 & York & 0 & 1 & 4 & 4 \\
6 & 77 & university & 0 & 0 & 1 & 1 \\
7 & 108 & Simcoe & 0 & 0 & 1 & 0 \\
8 & 277 & John & 1 & 1 & 1 & 0 \\
9 & 210 & Blue Jays way & 0 & 0 & 1 & 1 \\
10 & 45 & & $\mathbf{4}$ & $\mathbf{6}$ & $\mathbf{1 2}$ & $\mathbf{9}$ \\
\hline Totals & $\mathbf{1 6 3 8}$ & &
\end{tabular}

Stops based on a Stop Speed of $8 \mathrm{KPH}$. 
City of Toronto

Heading Second Line

Heading Third Line

\section{Average Speed (KPH) by Section}

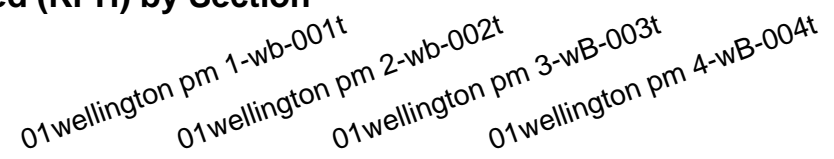

\begin{tabular}{|c|c|l|c|c|c|c|}
\hline $\begin{array}{c}\text { Node } \\
\text { \# }\end{array}$ & Length & Node Name & Run \#1 & Run \#2 & Run \#3 & Run \#4 \\
\hline 1 & 0 & & & & & \\
2 & 171 & church & 6.5 & 8.7 & 9.8 & 9.4 \\
3 & 303 & Yonge & 44.3 & 22.1 & 14.0 & 12.5 \\
4 & 193 & Bay & 13.3 & 12.4 & 16.9 & 21.5 \\
5 & 254 & York & 31.7 & 22.3 & 10.5 & 4.6 \\
6 & 77 & university & 24.4 & 35.0 & 4.1 & 6.1 \\
7 & 108 & Simcoe & 29.2 & 44.9 & 11.7 & 38.8 \\
8 & 277 & John & 32.2 & 20.4 & 14.4 & 40.2 \\
9 & 210 & Blue Jays way & 14.6 & 13.3 & 18.5 & 21.1 \\
10 & 45 & & 26.8 & 20.9 & 18.2 & 0.0 \\
\hline Totals & $\mathbf{1 6 3 8}$ & & $\mathbf{1 8 . 8}$ & $\mathbf{1 6 . 9}$ & $\mathbf{1 2 . 1}$ & $\mathbf{1 1 . 3}$ \\
\hline
\end{tabular}


City of Toronto

Heading Second Line

Heading Third Line

Total Delay (sec) by Section

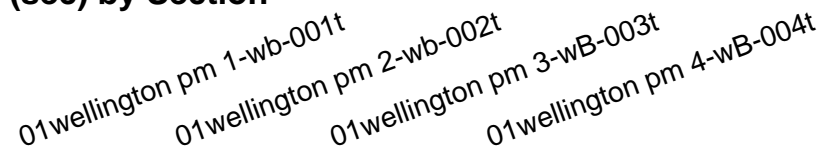

\begin{tabular}{|c|c|l|c|c|c|c|}
\hline $\begin{array}{c}\text { Node } \\
\text { \# }\end{array}$ & Length & \multicolumn{1}{|c|}{ Node Name } & Run \#1 & Run \#2 & Run \#3 & Run \#4 \\
\hline 1 & 0 & & & & & \\
2 & 171 & church & 87 & 63 & 55 & 57 \\
3 & 303 & Yonge & 6 & 31 & 58 & 68 \\
4 & 193 & Bay & 39 & 44 & 29 & 21 \\
5 & 254 & York & 14 & 25 & 74 & 180 \\
6 & 77 & university & 6 & 3 & 61 & 41 \\
7 & 108 & Simcoe & 7 & 2 & 27 & 3 \\
8 & 277 & John & 14 & 30 & 50 & 8 \\
9 & 210 & Blue Jays way & 38 & 45 & 28 & 15 \\
10 & 45 & & 3 & 5 & 6 & 0 \\
\hline Totals & $\mathbf{1 6 3 8}$ & & $\mathbf{2 1 4}$ & $\mathbf{2 4 8}$ & $\mathbf{3 8 8}$ & $\mathbf{3 9 3}$ \\
\hline
\end{tabular}

Total Delay based on a Normal Speed of $60 \mathrm{KPH}$. 


\section{City of Toronto}

Heading Second Line

Heading Third Line

Overall Output Statistics

Study Name : Wellington off peak

Study Date : 04/27/2015

Page No. : : 1

\begin{tabular}{|c|c|c|c|c|c|c|c|c|c|}
\hline $\begin{array}{c}\text { Node } \\
\# \\
\end{array}$ & Length & Node & $\begin{array}{c}\text { Travel } \\
\text { Time } \\
\end{array}$ & $\begin{array}{c}\text { \# of } \\
\text { Stops }\end{array}$ & $\begin{array}{c}\text { Avg } \\
\text { Speed }\end{array}$ & $\begin{array}{l}\text { Total } \\
\text { Delay }\end{array}$ & $\begin{array}{l}\text { Time <= } \\
10 \mathrm{KPH}\end{array}$ & $\begin{array}{l}\text { Time <= } \\
50 \mathrm{KPH}\end{array}$ & $\begin{array}{l}\text { Time <= } \\
70 \mathrm{KPH}\end{array}$ \\
\hline 1 & 0 & & & & & & & & \\
\hline 2 & 133 & church & 50.2 & 1.0 & 9.5 & 42.2 & 32.4 & 50.2 & 50.2 \\
\hline 3 & 295 & Yonge & 49.6 & 0.8 & 21.4 & 31.6 & 18.0 & 49.6 & 49.6 \\
\hline 4 & 209 & Bay & 48.4 & 0.8 & 15.5 & 35.4 & 20.4 & 48.4 & 48.4 \\
\hline 5 & 244 & York & 62.4 & 2.4 & 14.1 & 47.4 & 27.0 & 62.4 & 62.4 \\
\hline 6 & 90 & University & 22.8 & 0.4 & 14.2 & 17.2 & 11.4 & 22.8 & 22.8 \\
\hline 7 & 123 & Simcoe & 33.2 & 0.6 & 13.3 & 25.4 & 18.6 & 33.0 & 33.2 \\
\hline 8 & 298 & John & 54.2 & 0.8 & 19.8 & 36.0 & 23.2 & 54.2 & 54.2 \\
\hline 9 & 206 & Blue Jays Way & 42.6 & 0.6 & 17.4 & 30.8 & 22.8 & 42.2 & 42.2 \\
\hline 10 & 0 & & & & & & & & \\
\hline Total & 1,598 & & 364.0 & 7.4 & 15.8 & 266.2 & 173.8 & 363.2 & 363.4 \\
\hline
\end{tabular}

Stats based on 5 BEFORE runs.

Stops based on a Stop Speed of $8 \mathrm{KPH}$.

Total Delay based on a Normal Speed of $60 \mathrm{KPH}$. 


\section{City of Toronto}

Heading Second Line

Heading Third Line

Detailed Statistics By Run
Study Name : Wellington off peak

Study Date : 04/27/2015

Page No. : : 2

Travel Time (sec) by Section

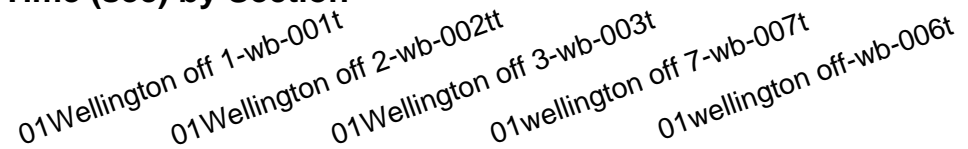

\begin{tabular}{|c|c|l|c|c|c|c|c|}
\hline $\begin{array}{c}\text { Node } \\
\text { \# }\end{array}$ & Length & Node Name & Run \#1 & Run \#2 & Run \#3 & Run \#4 & Run \#5 \\
\hline 1 & 0 & & & & & & \\
2 & 133 & church & 63 & 42 & 49 & 59 & 38 \\
3 & 295 & Yonge & 74 & 51 & 38 & 59 & 26 \\
4 & 209 & Bay & 38 & 56 & 70 & 55 & 23 \\
5 & 244 & York & 32 & 66 & 80 & 106 & 28 \\
6 & 90 & University & 9 & 35 & 48 & 14 & 8 \\
7 & 123 & Simcoe & 10 & 24 & 65 & 17 & 50 \\
8 & 298 & John & 60 & 29 & 57 & 58 & 67 \\
9 & 206 & Blue Jays Way & 60 & 50 & 20 & 65 & 18 \\
10 & 0 & & 0 & 1 & 1 & 0 & 1 \\
\hline Totals & $\mathbf{1 5 9 8}$ & & $\mathbf{3 4 6}$ & $\mathbf{3 5 4}$ & $\mathbf{4 2 8}$ & $\mathbf{4 3 3}$ & $\mathbf{2 5 9}$ \\
\hline
\end{tabular}




\section{City of Toronto}

Heading Second Line

Heading Third Line

Detailed Statistics By Run
Study Name : Wellington off peak

Study Date : 04/27/2015

Page No. : : 3

Number of Stops by Section

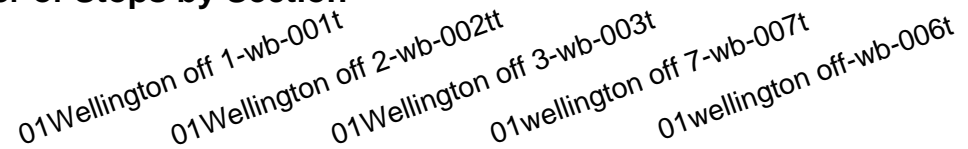

\begin{tabular}{|c|c|l|c|c|c|c|c|}
\hline $\begin{array}{c}\text { Node } \\
\text { \# }\end{array}$ & Length & \multicolumn{1}{|c|}{ Node Name } & Run \#1 & Run \#2 & Run \#3 & Run \#4 & Run \#5 \\
\hline 1 & 0 & & & & & & \\
2 & 133 & church & 1 & 1 & 1 & 1 & 1 \\
3 & 295 & Yonge & 1 & 1 & 1 & 1 & 0 \\
4 & 209 & Bay & 1 & 1 & 1 & 1 & 0 \\
5 & 244 & York & 1 & 3 & 2 & 6 & 0 \\
6 & 90 & University & 0 & 1 & 1 & 0 & 0 \\
7 & 123 & Simcoe & 1 & 1 & 1 & 0 & 1 \\
8 & 298 & John & 1 & 1 & 0 & 1 & 1 \\
9 & 206 & Blue Jays Way & 0 & 0 & 0 & 0 & 0 \\
10 & 0 & & $\mathbf{6}$ & $\mathbf{9}$ & $\mathbf{8}$ & $\mathbf{1 1}$ & $\mathbf{3}$ \\
\hline Totals & $\mathbf{1 5 9 8}$ & &
\end{tabular}

Stops based on a Stop Speed of $8 \mathrm{KPH}$. 
City of Toronto

Heading Second Line

Heading Third Line

Detailed Statistics By Run

Study Name : Wellington off peak

Study Date : 04/27/2015

Page No. : $\mathbf{4}$

\section{Average Speed (KPH) by Section}

of wellington off $1-w b-00$ tt
of Wellington of 2 wb-

\begin{tabular}{|c|c|l|c|c|c|c|c|}
\hline $\begin{array}{c}\text { Node } \\
\text { \# }\end{array}$ & Length & Node Name & Run \#1 & Run \#2 & Run \#3 & Run \#4 & Run \#5 \\
\hline 1 & 0 & & & & & & \\
2 & 133 & church & 7.6 & 11.4 & 9.8 & 8.3 & 12.8 \\
3 & 295 & Yonge & 14.4 & 21.3 & 28.0 & 18.0 & 40.7 \\
4 & 209 & Bay & 19.9 & 13.4 & 10.7 & 13.6 & 32.8 \\
5 & 244 & York & 27.7 & 12.9 & 11.1 & 8.4 & 32.6 \\
6 & 90 & University & 39.3 & 10.2 & 6.9 & 22.5 & 35.4 \\
7 & 123 & Simcoe & 40.9 & 18.3 & 6.8 & 26.3 & 9.3 \\
8 & 298 & John & 17.9 & 37.4 & 19.1 & 18.6 & 15.9 \\
9 & 206 & Blue Jays Way & 9.9 & 14.0 & 37.0 & 10.3 & 42.5 \\
10 & 0 & & 0.0 & 0.0 & 35.4 & 0.0 & 46.7 \\
\hline Totals & $\mathbf{1 5 9 8}$ & & $\mathbf{1 6 . 3}$ & $\mathbf{1 6 . 3}$ & $\mathbf{1 3 . 6}$ & $\mathbf{1 3 . 2}$ & $\mathbf{2 2 . 5}$ \\
\hline
\end{tabular}


City of Toronto

Heading Second Line

Heading Third Line

Detailed Statistics By Run

Study Name : Wellington off peak

Study Date : 04/27/2015

Page No. : $\mathbf{5}$

Total Delay (sec) by Section

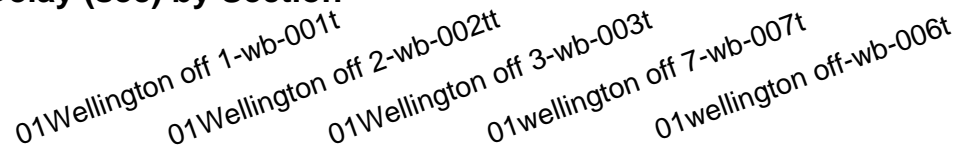

\begin{tabular}{|c|c|l|c|c|c|c|c|}
\hline $\begin{array}{c}\text { Node } \\
\text { \# }\end{array}$ & Length & Node Name & Run \#1 & Run \#2 & Run \#3 & Run \#4 & Run \#5 \\
\hline 1 & 0 & & & & & & \\
2 & 133 & church & 55 & 34 & 41 & 51 & 30 \\
3 & 295 & Yonge & 56 & 33 & 20 & 41 & 8 \\
4 & 209 & Bay & 25 & 43 & 57 & 42 & 10 \\
5 & 244 & York & 17 & 51 & 65 & 91 & 13 \\
6 & 90 & University & 3 & 29 & 42 & 9 & 3 \\
7 & 123 & Simcoe & 2 & 16 & 57 & 10 & 42 \\
8 & 298 & John & 42 & 10 & 39 & 40 & 49 \\
9 & 206 & Blue Jays Way & 50 & 38 & 7 & 54 & 5 \\
10 & 0 & & 0 & 1 & 0 & 0 & 0 \\
\hline Totals & $\mathbf{1 5 9 8}$ & & $\mathbf{2 5 0}$ & $\mathbf{2 5 5}$ & $\mathbf{3 2 8}$ & $\mathbf{3 3 8}$ & $\mathbf{1 6 0}$ \\
\hline
\end{tabular}

Total Delay based on a Normal Speed of $60 \mathrm{KPH}$. 


\section{City of Toronto}

Heading Second Line

Heading Third Line

Overall Output Statistics

Study Name : Wellington Day 2 AM

Study Date : 04/27/2015

Page No. : : 1

\begin{tabular}{|c|c|l|c|c|c|c|c|c|c|}
\hline $\begin{array}{c}\text { Node } \\
\#\end{array}$ & Length & Node & $\begin{array}{c}\text { Travel } \\
\text { Time }\end{array}$ & $\begin{array}{c}\text { \# of } \\
\text { Stops }\end{array}$ & $\begin{array}{c}\text { Avg } \\
\text { Speed }\end{array}$ & $\begin{array}{c}\text { Total } \\
\text { Delay }\end{array}$ & $\begin{array}{c}\text { Time }<= \\
\mathbf{1 0} \mathbf{K P H}\end{array}$ & $\begin{array}{c}\text { Time }<= \\
\mathbf{5 0} \mathbf{K P H}\end{array}$ & $\begin{array}{c}\text { Time }<= \\
\mathbf{7 0} \mathbf{K P H}\end{array}$ \\
\hline 1 & 0 & & & & & & & & \\
2 & 140 & church & 69.1 & 1.0 & 7.3 & 60.6 & 50.9 & 69.1 & 69.1 \\
3 & 293 & yonge & 67.3 & 1.0 & 15.7 & 49.3 & 36.3 & 66.9 & 67.3 \\
4 & 197 & Bay & 42.9 & 0.9 & 16.5 & 30.9 & 19.6 & 42.9 & 42.9 \\
5 & 271 & York & 67.3 & 1.6 & 14.5 & 50.9 & 32.1 & 66.0 & 67.3 \\
6 & 84 & university & 35.4 & 0.9 & 8.5 & 30.4 & 23.6 & 35.4 & 35.4 \\
7 & 129 & Simcoe & 14.6 & 0.0 & 31.8 & 6.6 & 0.0 & 14.6 & 14.6 \\
8 & 317 & John & 40.3 & 0.4 & 28.3 & 21.1 & 8.4 & 39.1 & 40.3 \\
9 & 211 & Blue Jays Way & 38.9 & 0.4 & 19.5 & 28.0 & 20.9 & 37.3 & 38.1 \\
10 & 61 & & 1.3 & 0.0 & 170.7 & 0.4 & 0.0 & 1.1 & 1.1 \\
\hline Total & $\mathbf{1 , 7 0 3}$ & & $\mathbf{3 7 7 . 0}$ & $\mathbf{6 . 1}$ & $\mathbf{1 6 . 3}$ & $\mathbf{2 7 8 . 1}$ & $\mathbf{1 9 1 . 7}$ & $\mathbf{3 7 2 . 4}$ & $\mathbf{3 7 6 . 1}$ \\
\hline
\end{tabular}

Stats based on 7 BEFORE runs.

Stops based on a Stop Speed of $8 \mathrm{KPH}$.

Total Delay based on a Normal Speed of $60 \mathrm{KPH}$. 


\section{City of Toronto}

Heading Second Line

Heading Third Line

Detailed Statistics By Run

Study Name : Wellington Day 2 AM

Study Date : 04/27/2015

Page No. : 2

\section{Travel Time (sec) by Section}

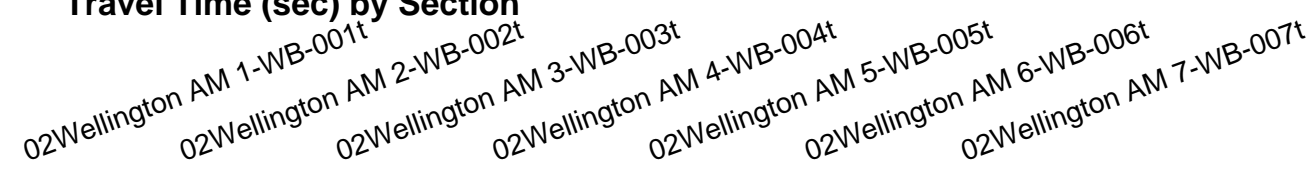

\begin{tabular}{|c|c|l|c|c|c|c|c|c|c|}
\hline $\begin{array}{c}\text { Node } \\
\text { \# }\end{array}$ & Length & Node Name & Run \#1 & Run \#2 & Run \#3 & Run \#4 & Run \#5 & Run \#6 & Run \#7 \\
\hline 1 & 0 & & & & & & & & \\
2 & 140 & church & 50 & 78 & 65 & 77 & 57 & 72 & 85 \\
3 & 293 & yonge & 25 & 68 & 62 & 27 & 56 & 141 & 92 \\
4 & 197 & Bay & 16 & 35 & 60 & 68 & 16 & 56 & 49 \\
5 & 271 & York & 46 & 23 & 57 & 145 & 89 & 32 & 79 \\
6 & 84 & university & 37 & 14 & 56 & 30 & 8 & 73 & 30 \\
7 & 129 & Simcoe & 15 & 13 & 17 & 16 & 12 & 14 & 15 \\
8 & 317 & John & 36 & 31 & 24 & 25 & 26 & 75 & 65 \\
9 & 211 & Blue Jays Way & 17 & 55 & 66 & 13 & 82 & 21 & 18 \\
10 & 61 & & 2 & 0 & 0 & 0 & 0 & 7 & 0 \\
\hline Totals & $\mathbf{1 7 0 3}$ & & $\mathbf{2 4 4}$ & $\mathbf{3 1 7}$ & $\mathbf{4 0 7}$ & $\mathbf{4 0 1}$ & $\mathbf{3 4 6}$ & $\mathbf{4 9 1}$ & $\mathbf{4 3 3}$ \\
\hline
\end{tabular}




\section{City of Toronto}

Heading Second Line

Heading Third Line

Detailed Statistics By Run

Study Name : Wellington Day 2 AM

Study Date : 04/27/2015

Page No. : 3

\begin{tabular}{|c|c|c|c|c|c|c|c|c|c|}
\hline \multirow[b]{2}{*}{$\begin{array}{c}\text { Node } \\
\#\end{array}$} & \multicolumn{9}{|c|}{ 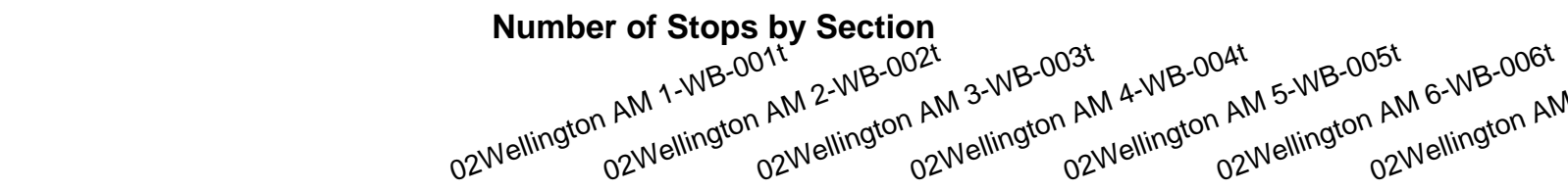 } \\
\hline & Length & Node Name & Run \#1 & Run \#2 & Run \#3 & Run \#4 & Run \#5 & Run \#6 & Run \#7 \\
\hline 1 & 0 & & & & & & & & \\
\hline 2 & 140 & church & 2 & 1 & 1 & 1 & 0 & 1 & 1 \\
\hline 3 & 293 & yonge & 0 & 1 & 1 & 0 & 1 & 3 & 1 \\
\hline 4 & 197 & Bay & 0 & 1 & 1 & 1 & 0 & 2 & 1 \\
\hline 5 & 271 & York & 2 & 0 & 1 & 4 & 2 & 0 & 2 \\
\hline 6 & 84 & university & 1 & 1 & 0 & 2 & 0 & 1 & 1 \\
\hline 7 & 129 & Simcoe & 0 & 0 & 0 & 0 & 0 & 0 & 0 \\
\hline 8 & 317 & John & 1 & 0 & 0 & 0 & 0 & 1 & 1 \\
\hline 9 & 211 & Blue Jays Way & 0 & 1 & 1 & 0 & 1 & 0 & 0 \\
\hline 10 & 61 & & 0 & 0 & 0 & 0 & 0 & 0 & 0 \\
\hline Totals & 1703 & & 6 & 5 & 5 & 8 & 4 & 8 & 7 \\
\hline
\end{tabular}

Stops based on a Stop Speed of $8 \mathrm{KPH}$. 
City of Toronto

Heading Second Line

Heading Third Line

Detailed Statistics By Run

Study Name : Wellington Day 2 AM

Study Date : 04/27/2015

Page No. : : 4

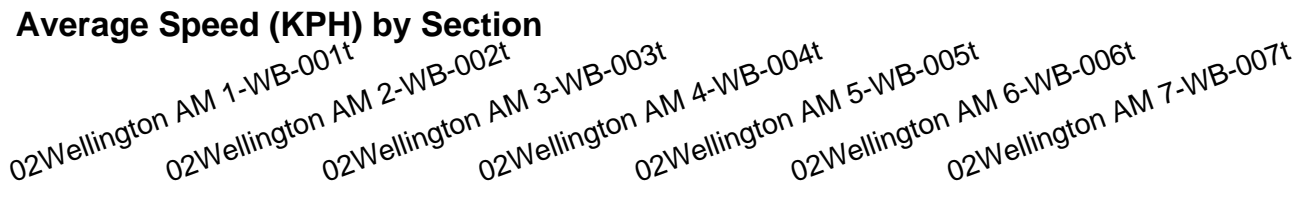

\begin{tabular}{|c|c|l|c|c|c|c|c|c|c|}
\hline $\begin{array}{c}\text { Node } \\
\text { \# }\end{array}$ & Length & Node Name & Run \#1 & Run \#2 & Run \#3 & Run \#4 & Run \#5 & Run \#6 & Run \#7 \\
\hline 1 & 0 & & & & & & & & \\
2 & 140 & church & 10.2 & 6.9 & 8.1 & 6.6 & 9.3 & 6.9 & 6.3 \\
3 & 293 & yonge & 42.5 & 15.4 & 17.1 & 40.0 & 18.6 & 7.4 & 11.2 \\
4 & 197 & Bay & 44.2 & 20.0 & 11.7 & 10.3 & 43.3 & 13.1 & 14.5 \\
5 & 271 & York & 21.3 & 42.4 & 16.6 & 6.6 & 11.3 & 30.1 & 12.5 \\
6 & 84 & university & 8.5 & 21.0 & 5.8 & 10.0 & 35.4 & 3.9 & 9.4 \\
7 & 129 & Simcoe & 30.6 & 38.1 & 28.0 & 30.4 & 41.8 & 33.1 & 30.7 \\
8 & 317 & John & 31.6 & 36.7 & 47.8 & 46.1 & 42.5 & 15.3 & 17.7 \\
9 & 211 & Blue Jays Way & 45.8 & 6.8 & 9.2 & 38.1 & 7.8 & 36.1 & 40.6 \\
10 & 61 & & 35.4 & 0.0 & 0.0 & 0.0 & 0.0 & 31.0 & 0.0 \\
\hline Totals & $\mathbf{1 7 0 3}$ & & $\mathbf{2 4 . 6}$ & $\mathbf{1 7 . 6}$ & $\mathbf{1 4 . 3}$ & $\mathbf{1 4 . 1}$ & $\mathbf{1 6 . 8}$ & $\mathbf{1 2 . 5}$ & $\mathbf{1 3 . 5}$ \\
\hline
\end{tabular}




\section{City of Toronto}

Heading Second Line

Heading Third Line

Detailed Statistics By Run

Study Name : Wellington Day 2 AM

Study Date : 04/27/2015

Page No. : : 5

Total Delay (sec) by Section

\begin{tabular}{|c|c|c|c|c|c|c|c|c|c|}
\hline $\begin{array}{c}\text { Node } \\
\#\end{array}$ & Length & Node Name & Run \#1 & Run \#2 & Run \#3 & Run \#4 & Run \#5 & Run \#6 & Run \#7 \\
\hline 1 & 0 & & & & & & & & \\
\hline 2 & 140 & church & 42 & 69 & 56 & 69 & 48 & 64 & 76 \\
\hline 3 & 293 & yonge & 7 & 50 & 44 & 9 & 38 & 123 & 74 \\
\hline 4 & 197 & Bay & 4 & 23 & 48 & 56 & 4 & 44 & 37 \\
\hline 5 & 271 & York & 30 & 7 & 41 & 129 & 72 & 15 & 62 \\
\hline 6 & 84 & university & 32 & 9 & 51 & 25 & 3 & 68 & 25 \\
\hline 7 & 129 & Simcoe & 7 & 5 & 9 & 8 & 4 & 6 & 7 \\
\hline 8 & 317 & John & 17 & 12 & 5 & 5 & 7 & 56 & 46 \\
\hline 9 & 211 & Blue Jays Way & 4 & 48 & 55 & 4 & 71 & 8 & 6 \\
\hline 10 & 61 & & 0 & 0 & 0 & 0 & 0 & 3 & 0 \\
\hline Totals & 1703 & & 143 & 223 & 309 & 305 & 247 & 387 & 333 \\
\hline
\end{tabular}

Total Delay based on a Normal Speed of $60 \mathrm{KPH}$. 


\section{City of Toronto}

Heading Second Line

Heading Third Line

Overall Output Statistics

Study Name : Wellington Day 2 PM

Study Date : 04/27/2015

Page No. : : 1

\begin{tabular}{|c|c|c|c|c|c|c|c|c|c|}
\hline $\begin{array}{c}\text { Node } \\
\# \\
\end{array}$ & Length & Node & $\begin{array}{c}\text { Travel } \\
\text { Time }\end{array}$ & $\begin{array}{c}\text { \# of } \\
\text { Stops }\end{array}$ & $\begin{array}{c}\text { Avg } \\
\text { Speed }\end{array}$ & $\begin{array}{l}\text { Total } \\
\text { Delay }\end{array}$ & $\begin{array}{l}\text { Time <= } \\
10 \mathrm{KPH}\end{array}$ & $\begin{array}{l}\text { Time <= } \\
50 \mathrm{KPH}\end{array}$ & $\begin{array}{l}\text { Time <= } \\
70 \mathrm{KPH}\end{array}$ \\
\hline 1 & 0 & & & & & & & & \\
\hline 2 & 212 & church & 55.7 & 0.8 & 13.7 & 42.7 & 28.2 & 55.7 & 55.7 \\
\hline 3 & 285 & Yonge & 58.5 & 0.8 & 17.5 & 41.5 & 27.7 & 58.5 & 58.5 \\
\hline 4 & 211 & Bay & 60.7 & 1.8 & 12.5 & 47.7 & 33.2 & 60.7 & 60.7 \\
\hline 5 & 226 & York & 54.0 & 1.2 & 15.1 & 40.0 & 22.7 & 53.8 & 54.0 \\
\hline 6 & 54 & University & 25.8 & 0.3 & 7.5 & 22.8 & 17.8 & 25.8 & 25.8 \\
\hline 7 & 112 & Simcoe & 35.5 & 0.5 & 11.4 & 28.5 & 19.5 & 35.5 & 35.5 \\
\hline 8 & 315 & John & 47.3 & 0.5 & 23.9 & 28.3 & 14.2 & 47.3 & 47.3 \\
\hline 9 & 214 & Blue Jays Way & 25.8 & 0.2 & 29.8 & 12.8 & 3.0 & 25.8 & 25.8 \\
\hline 10 & 58 & & 14.5 & 0.5 & 14.5 & 11.3 & 7.5 & 13.8 & 13.8 \\
\hline Total & 1,687 & & 377.8 & 6.7 & 16.1 & 275.7 & 173.7 & 377.0 & 377.2 \\
\hline
\end{tabular}

Stats based on 6 BEFORE runs.

Stops based on a Stop Speed of $8 \mathrm{KPH}$.

Total Delay based on a Normal Speed of $60 \mathrm{KPH}$. 


\section{City of Toronto}

Heading Second Line

Heading Third Line

Detailed Statistics By Run

Study Name : Wellington Day 2 PM

Study Date : 04/27/2015

Page No. : 2

Travel Time (sec) by Section

02 Wellington $P M$
02 Wellingtion $P M$
$02 W$ ellington $P M$

\begin{tabular}{|c|c|l|c|c|c|c|c|c|}
\hline $\begin{array}{c}\text { Node } \\
\text { \# }\end{array}$ & Length & \multicolumn{1}{|c|}{ Node Name } & Run \#1 & Run \#2 & Run \#3 & Run \#4 & Run \#5 & Run \#6 \\
\hline 1 & 0 & & & & & & & \\
2 & 212 & lhurch & 59 & 99 & 50 & 28 & 26 & 72 \\
3 & 285 & Yonge & 64 & 23 & 63 & 86 & 60 & 55 \\
4 & 211 & Bay & 50 & 40 & 61 & 50 & 67 & 96 \\
5 & 226 & York & 32 & 41 & 26 & 46 & 36 & 143 \\
6 & 54 & University & 24 & 39 & 11 & 48 & 24 & 9 \\
7 & 112 & Simcoe & 47 & 33 & 19 & 47 & 53 & 14 \\
8 & 315 & John & 32 & 30 & 69 & 55 & 31 & 67 \\
9 & 214 & Blue Jays Way & 23 & 20 & 26 & 19 & 24 & 43 \\
10 & 58 & & 7 & 12 & 26 & 35 & 4 & 3 \\
\hline Totals & $\mathbf{1 6 8 7}$ & & $\mathbf{3 3 8}$ & $\mathbf{3 3 7}$ & $\mathbf{3 5 1}$ & $\mathbf{4 1 4}$ & $\mathbf{3 2 5}$ & $\mathbf{5 0 2}$ \\
\hline
\end{tabular}




\section{City of Toronto}

Heading Second Line

Heading Third Line

Detailed Statistics By Run
Study Name : Wellington Day 2 PM

Study Date : 04/27/2015

Page No. : 3

Number of Stops by Section

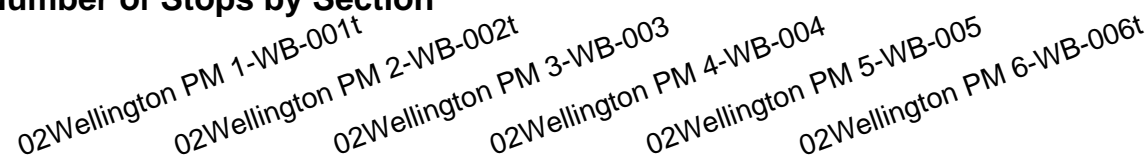

\begin{tabular}{|c|c|l|c|c|c|c|c|c|}
\hline $\begin{array}{c}\text { Node } \\
\text { \# }\end{array}$ & Length & \multicolumn{1}{|c|}{ Node Name } & Run \#1 & Run \#2 & Run \#3 & Run \#4 & Run \#5 & Run \#6 \\
\hline 1 & 0 & & & & & & & \\
2 & 212 & lhurch & 1 & 1 & 1 & 1 & 0 & 1 \\
3 & 285 & Yonge & 1 & 0 & 1 & 1 & 1 & 1 \\
4 & 211 & Bay & 1 & 1 & 1 & 1 & 1 & 6 \\
5 & 226 & York & 1 & 1 & 0 & 2 & 1 & 3 \\
6 & 54 & University & 0 & 1 & 0 & 0 & 0 & 0 \\
7 & 112 & Simcoe & 0 & 0 & 1 & 1 & 0 & 1 \\
8 & 315 & John & 0 & 0 & 0 & 0 & 0 & 1 \\
9 & 214 & Blue Jays Way & 0 & 1 & 1 & 1 & 0 & 0 \\
10 & 58 & & $\mathbf{4}$ & $\mathbf{6}$ & $\mathbf{5}$ & $\mathbf{8}$ & $\mathbf{4}$ & $\mathbf{1 3}$ \\
\hline Totals & $\mathbf{1 6 8 7}$ & &
\end{tabular}

Stops based on a Stop Speed of $8 \mathrm{KPH}$. 
City of Toronto

Heading Second Line

Heading Third Line

Detailed Statistics By Run

Study Name : Wellington Day 2 PM

Study Date : 04/27/2015

Page No. : : 4

\section{Average Speed (KPH) by Section}

$$
\begin{aligned}
& 02 \text { Wellington } P M \\
& 02 W \text { ellington } P M \\
& 02 W \text { ellington } P M \\
& 02 W \text { ellington } P M
\end{aligned}
$$

\begin{tabular}{|c|c|l|c|c|c|c|c|c|}
\hline $\begin{array}{c}\text { Node } \\
\text { \# }\end{array}$ & Length & \multicolumn{1}{|c|}{ Node Name } & Run \#1 & Run \#2 & Run \#3 & Run \#4 & Run \#5 & Run \#6 \\
\hline 1 & 0 & & & & & & & \\
2 & 212 & church & 13.0 & 8.0 & 15.7 & 27.7 & 29.4 & 10.7 \\
3 & 285 & Yonge & 16.4 & 43.3 & 16.1 & 11.9 & 17.4 & 18.9 \\
4 & 211 & Bay & 14.8 & 19.0 & 12.3 & 15.0 & 11.2 & 7.8 \\
5 & 226 & York & 25.6 & 20.2 & 31.5 & 17.6 & 22.4 & 5.7 \\
6 & 54 & University & 7.6 & 4.6 & 17.8 & 4.2 & 8.3 & 21.6 \\
7 & 112 & Simcoe & 9.0 & 12.1 & 21.7 & 8.6 & 7.6 & 30.3 \\
8 & 315 & John & 35.4 & 37.8 & 16.5 & 20.7 & 37.3 & 16.7 \\
9 & 214 & Blue Jays Way & 33.5 & 38.8 & 29.7 & 40.8 & 31.9 & 17.8 \\
10 & 58 & & 29.2 & 19.0 & 8.3 & 6.0 & 19.3 & 16.9 \\
\hline Totals & $\mathbf{1 6 8 7}$ & & $\mathbf{1 8 . 0}$ & $\mathbf{1 8 . 1}$ & $\mathbf{1 7 . 4}$ & $\mathbf{1 4 . 7}$ & $\mathbf{1 8 . 3}$ & $\mathbf{1 1 . 8}$ \\
\hline
\end{tabular}




\section{City of Toronto}

Heading Second Line

Heading Third Line

Detailed Statistics By Run

Study Name : Wellington Day 2 PM

Study Date : 04/27/2015

Page No. : 5

Total Delay (sec) by Section

02 Wellington $P M$
02 Wellington $P M$
$02 W$ ellington $P M$

\begin{tabular}{|c|c|l|c|c|c|c|c|c|}
\hline $\begin{array}{c}\text { Node } \\
\text { \# }\end{array}$ & Length & \multicolumn{1}{|c|}{ Node Name } & Run \#1 & Run \#2 & Run \#3 & Run \#4 & Run \#5 & Run \#6 \\
\hline 1 & 0 & & & & & & & \\
2 & 212 & church & 46 & 86 & 37 & 15 & 13 & 59 \\
3 & 285 & Yonge & 47 & 6 & 46 & 69 & 43 & 38 \\
4 & 211 & Bay & 37 & 27 & 48 & 37 & 54 & 83 \\
5 & 226 & York & 18 & 27 & 12 & 32 & 22 & 129 \\
6 & 54 & University & 21 & 36 & 8 & 45 & 21 & 6 \\
7 & 112 & Simcoe & 40 & 26 & 12 & 40 & 46 & 7 \\
8 & 315 & John & 13 & 11 & 50 & 36 & 12 & 48 \\
9 & 214 & Blue Jays Way & 10 & 7 & 13 & 6 & 11 & 30 \\
10 & 58 & & 3 & 8 & 22 & 31 & 2 & 2 \\
\hline Totals & $\mathbf{1 6 8 7}$ & & $\mathbf{2 3 5}$ & $\mathbf{2 3 4}$ & $\mathbf{2 4 8}$ & $\mathbf{3 1 1}$ & $\mathbf{2 2 4}$ & $\mathbf{4 0 2}$ \\
\hline
\end{tabular}

Total Delay based on a Normal Speed of $60 \mathrm{KPH}$. 


\section{APPENDIX E}

Volume Balancing 


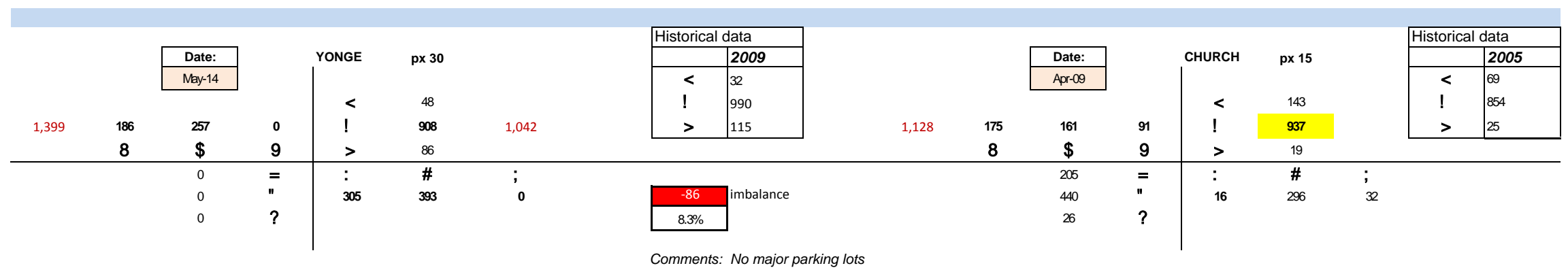

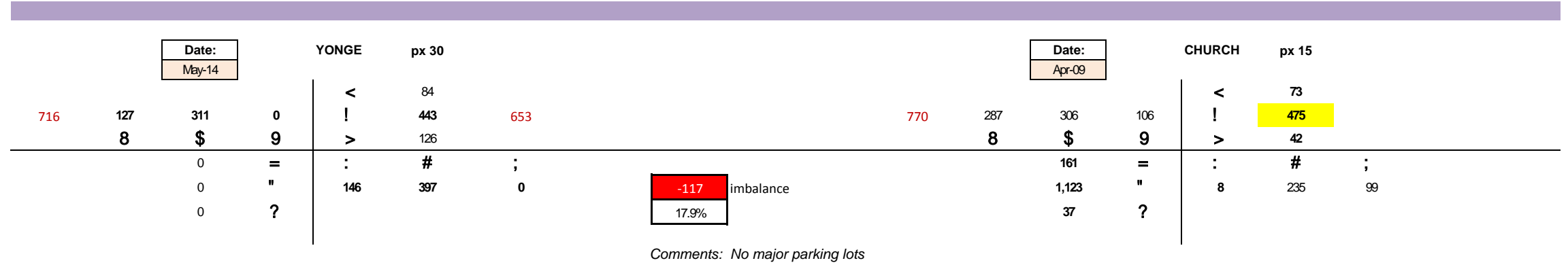

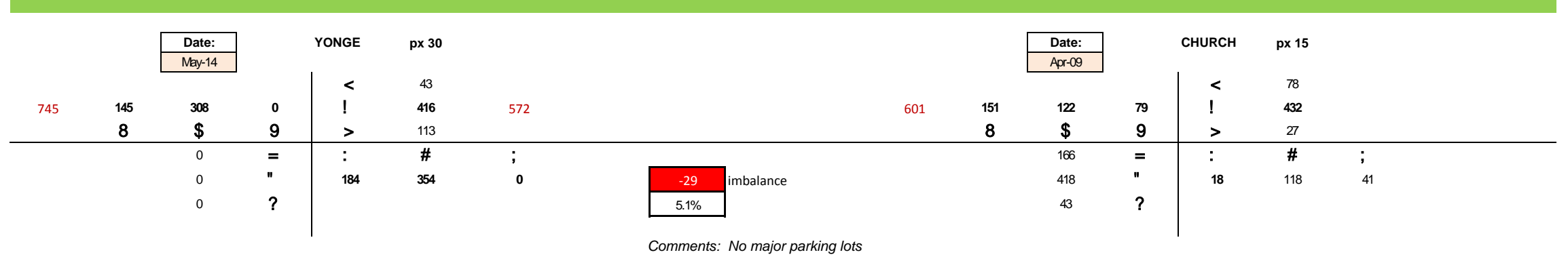




\begin{tabular}{|c|c|c|c|c|c|c|c|c|c|c|c|c|c|c|c|c|}
\hline \multirow{6}{*}{919} & \multirow{6}{*}{0} & \multirow{5}{*}{$\begin{array}{c}\text { Date: } \\
\text { Aug-12 } \\
0\end{array}$} & \multirow{6}{*}{0} & \multirow{5}{*}{ YORK } & \multirow{3}{*}{$p \times 71$} & & Historical data & \multirow[b]{5}{*}{1,415} & \multirow[b]{5}{*}{154} & \multirow{2}{*}{ Date: } & \multirow{2}{*}{\multicolumn{2}{|c|}{ BAY }} & \multirow[b]{2}{*}{$\mathrm{p} \times 60$} & \multicolumn{2}{|r|}{ Historical data } & \\
\hline & & & & & & & 2007 & & & & & & & \multirow{5}{*}{1,228} & \multirow{4}{*}{\begin{tabular}{|l|}
2005 \\
134 \\
1102 \\
124
\end{tabular}} & \\
\hline & & & & & & & 214 & & & \multirow{4}{*}{$\begin{array}{c}\text { Alg-09 } \\
418\end{array}$} & \multirow{4}{*}{0} & & \multirow{3}{*}{$\begin{array}{c}34 \\
1,119\end{array}$} & & & \\
\hline & & & & & 210 & & 810 & & & & & & & & & \\
\hline & & & & & 795 & 1,005 & 0 & & & & & & & & & \\
\hline & & & & & 0 & & & & & & & & 75 & & & \\
\hline & & 0 & & & & & & & & 0 & & & & & & \\
\hline & & 0 & & 124 & 646 & 0 & -410 & Iimbalance & & 0 & & 142 & 744 & 0 & -171 & Jimbalance \\
\hline & & 0 & & & & & $40.8 \%$ & & & 0 & & & & & $13.9 \%$ & \\
\hline
\end{tabular}

Comments: At least 3 major parking lots

Comments: At least 2 major parking lots

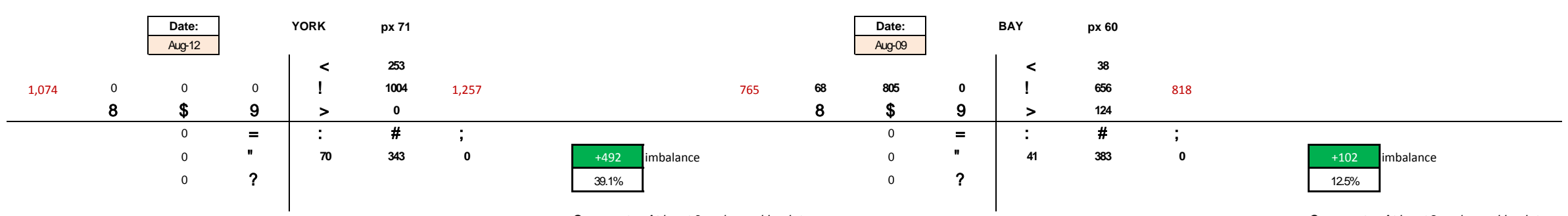

Comments: At least 3 major parking lots

Comments: At least 2 major parking lots

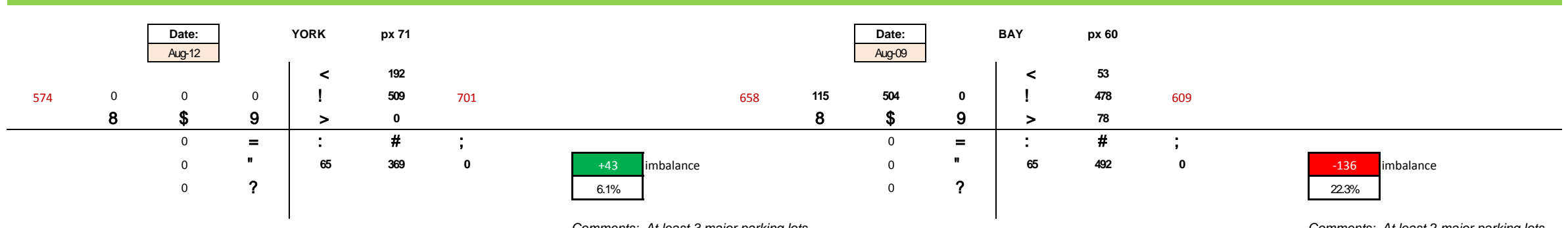

Comments: At least 3 major parking lots 


\begin{tabular}{|c|c|c|c|c|c|c|c|c|c|c|c|c|c|c|c|c|c|c|}
\hline \multirow{6}{*}{815} & \multirow{6}{*}{127} & \multirow{3}{*}{$\begin{array}{l}\text { Date: } \\
\text { Nov-09 }\end{array}$} & & \multirow{5}{*}{ SIMCOE } & \multirow{3}{*}{$p \times 264$} & & \multicolumn{2}{|l|}{ Historical data } & & & \multirow[b]{2}{*}{ Date: } & \multirow{2}{*}{\multicolumn{2}{|c|}{ UNIVERSITY }} & \multirow[b]{2}{*}{ px 76} & & \multicolumn{3}{|l|}{ Historical data } \\
\hline & & & & & & & 2007 & 2003 & & & & & & & & \begin{tabular}{|l|l} 
& 2009 \\
\end{tabular} & 2006 & 2002 \\
\hline & & & & & & & 0 & 0 & & & May-11 & & & & & 143 & 177 & 127 \\
\hline & & & & & 0 & & 464 & 650 & & & & & & 91 & & 574 & 7134 & 462 \\
\hline & & 197 & 0 & & 591 & 763 & 94 & 102 & 830 & 128 & 1,152 & 0 & & 597 & 769 & 109 & 137 & 137 \\
\hline & & & & & 172 & & & & & & & & & 81 & & & & \\
\hline & & 0 & & & & & & & & & 0 & & & & & & & \\
\hline & & 0 & & 97 & 0 & 0 & -67 & Iimbalance & & & 0 & & 105 & 917 & 0 & & -150 & Jimbalance \\
\hline & & 43 & & & & & $8.8 \%$ & & & & 0 & & & & & & $19.5 \%$ & \\
\hline
\end{tabular}

Comments: Several major parking lots

comments: A couple smaller parking lots

Comments: 1 major parking lot

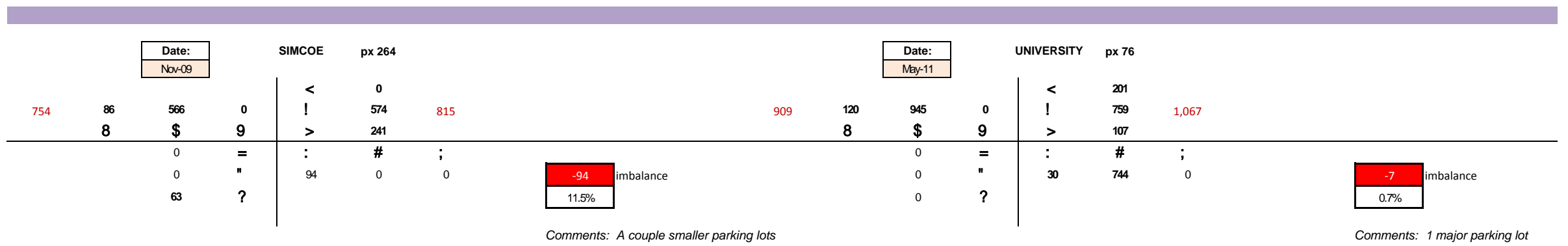

Comments: Several major parking lots

Comments: A couple smaller parking lots

Comments: 1 major parking lot

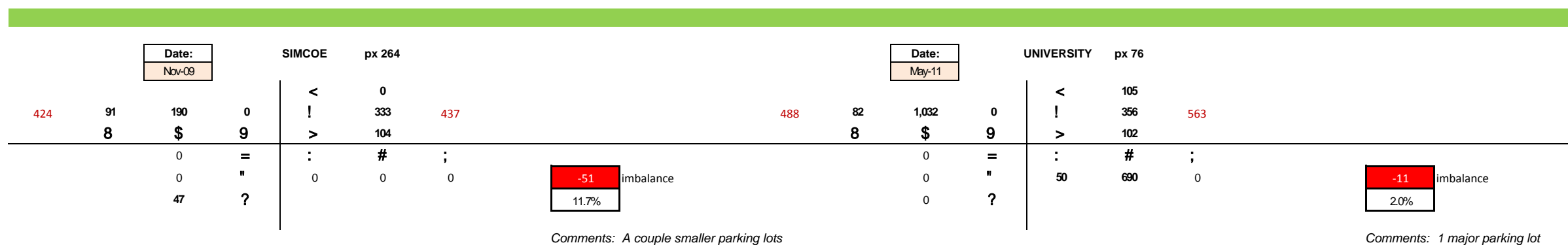

Comments: Several major parking lots

Comments: A couple smaller parking lots

Comments: 1 major parking lot 


\begin{tabular}{|c|c|c|c|c|c|c|c|c|c|c|c|c|c|c|c|c|c|c|}
\hline \multirow{6}{*}{97} & \multirow{6}{*}{22} & \multirow{3}{*}{\begin{tabular}{|l|} 
Date: \\
Jul-11
\end{tabular}} & \multirow{2}{*}{\multicolumn{2}{|c|}{ BLUE JAYS WAY }} & \multirow[b]{2}{*}{ px 1489} & & \multicolumn{2}{|l|}{ Historical data } & & & \multirow{3}{*}{\begin{tabular}{|l|l|} 
Date: \\
Apr-09
\end{tabular}} & & \multirow{3}{*}{ JOHN } & \multirow[b]{2}{*}{$\mathrm{px} 1489$} & & \multicolumn{2}{|l|}{ Historical data } & \multirow[b]{2}{*}{2000} \\
\hline & & & & & & & \begin{tabular}{|l|l} 
& 2008 \\
\end{tabular} & 2003 & & & & & & & & \begin{tabular}{|l|l|}
2008 \\
\end{tabular} & 2005 & \\
\hline & & & & & & & 61 & 56 & & & & & & & & 125 & 141 & 111 \\
\hline & & & & & 82 & & 71 & 10 & & & & & & 150 & & 227 & 201 & 309 \\
\hline & & 328 & 0 & & 61 & 252 & 82 & 98 & 381 & 55 & 258 & 92 & & 311 & 497 & 68 & 83 & 104 \\
\hline & & & & & 109 & & & & & & & & & 36 & & & & \\
\hline & & 24 & & & & & & & & & 0 & & & & & & & \\
\hline & & 0 & & 14 & 625 & 0 & -129 & imbalance & & & 0 & & 15 & 381 & $2 \pi$ & & -318 & Iimbalance - w \\
\hline & & 33 & & & & & $51.2 \%$ & & & & 0 & & & & & & $64.0 \%$ & \\
\hline & & & & & & & Comments: & $\begin{array}{l}\text { No major pa } \\
\text { using SB lan }\end{array}$ & $\begin{array}{l}\text { motoris } \\
\text { t St. we }\end{array}$ & $\begin{array}{l}\text { servec } \\
\text { John S }\end{array}$ & & & & & & & $\begin{array}{l}-326 \\
117.7 \%\end{array}$ & Iimbalance - EB \\
\hline
\end{tabular}

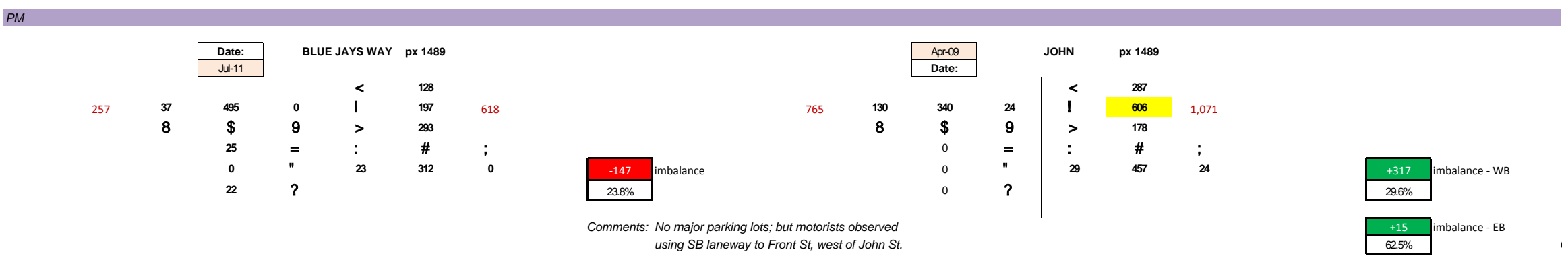

Off Peak

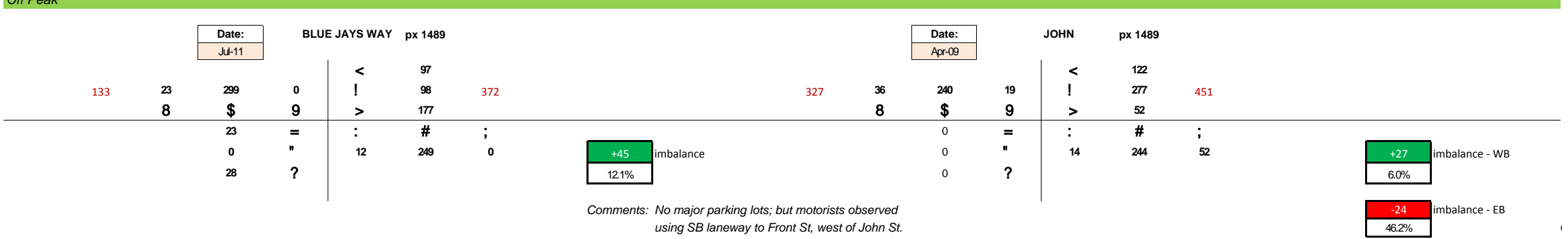




\section{APPENDIX F}

Detailed MOE 


\begin{tabular}{|c|c|c|c|c|c|c|c|c|}
\hline \multicolumn{9}{|c|}{ 15: Church \& Wellington St } \\
\hline \multirow[b]{2}{*}{ Lane Group } & \multicolumn{3}{|c|}{ AM - Baseline } & \multicolumn{3}{|c|}{ AM - Optimized 1} & \multicolumn{2}{|c|}{ Difference } \\
\hline & v/c Ratio & Total Delay & $\begin{array}{c}\text { Level of } \\
\text { Service (LOS) }\end{array}$ & v/c Ratio & Total Delay & $\begin{array}{c}\text { Level of } \\
\text { Service (LOS) }\end{array}$ & v/c Ratio & Total Delay \\
\hline EBL & 0.81 & 53.6 & D & 0.81 & 53.6 & D & 0 & 0 \\
\hline EBT & 0.75 & 38.5 & $\mathrm{D}$ & 0.75 & 38.5 & $\mathrm{D}$ & 0 & 0 \\
\hline EBR & 0.11 & 0.7 & $A$ & 0.11 & 0.7 & $A$ & 0 & 0 \\
\hline WBL & 0.07 & 26.1 & C & 0.07 & 26.1 & C & 0 & 0 \\
\hline WBT & 1.14 & 108.2 & $\mathrm{~F}$ & 1.14 & 108.2 & $\mathrm{~F}$ & 0 & 0 \\
\hline WBR & 0.22 & 1.6 & A & 0.22 & 1.6 & A & 0 & 0 \\
\hline \multicolumn{9}{|l|}{ NBL } \\
\hline NBT & 0.66 & 35.4 & $\mathrm{D}$ & 0.66 & 35.4 & $\mathrm{D}$ & 0 & 0 \\
\hline \multicolumn{9}{|l|}{ NBR } \\
\hline \multicolumn{9}{|l|}{ SBL } \\
\hline SBT & 0.86 & 36.9 & $\mathrm{D}$ & 0.86 & 36.9 & $\mathrm{D}$ & 0 & 0 \\
\hline \multicolumn{9}{|l|}{ SBR } \\
\hline & & & & & & & & \\
\hline & & & & & & & & \\
\hline & & & & & & & & \\
\hline & & & & & & & & \\
\hline & & & & & & & & \\
\hline & & & & & & & & \\
\hline
\end{tabular}

\begin{tabular}{|c|c|c|c|c|c|c|c|c|}
\hline \multicolumn{9}{|c|}{ 30: Yonge \& Wellington St } \\
\hline \multirow[b]{2}{*}{ Lane Group } & \multicolumn{3}{|c|}{ AM - Baseline } & \multicolumn{3}{|c|}{ AM - Optimized 1} & \multicolumn{2}{|c|}{ Difference } \\
\hline & v/c Ratio & Total Delay & $\begin{array}{c}\text { Level of } \\
\text { Service (LOS) }\end{array}$ & v/c Ratio & Total Delay & $\begin{array}{c}\text { Level of } \\
\text { Service (LOS) }\end{array}$ & v/c Ratio & Total Delay \\
\hline \multicolumn{9}{|l|}{ EBL } \\
\hline \multicolumn{9}{|l|}{ EBT } \\
\hline \multicolumn{9}{|l|}{ EBR } \\
\hline \multicolumn{9}{|l|}{ WBL } \\
\hline WBT & 0.88 & 36 & D & 0.88 & 36 & D & 0 & 0 \\
\hline \multicolumn{9}{|l|}{ WBR } \\
\hline \multicolumn{9}{|l|}{ NBL } \\
\hline NBT & 0.75 & 17.6 & B & 0.75 & 17.6 & B & 0 & 0 \\
\hline \multicolumn{9}{|l|}{ NBR } \\
\hline \multicolumn{9}{|l|}{ SBL } \\
\hline SBT & 0.42 & 16.2 & B & 0.42 & 16.2 & B & 0 & 0 \\
\hline \multicolumn{9}{|l|}{ SBR } \\
\hline & & & & & & & & \\
\hline & & & & & & & & \\
\hline & & & & & & & & \\
\hline & & & & & & & & \\
\hline & & & & & & & & \\
\hline & & & & & & & & \\
\hline
\end{tabular}




\begin{tabular}{|c|c|c|c|c|c|c|c|c|}
\hline \multicolumn{9}{|c|}{ 60: Bay \& Wellington St } \\
\hline \multirow[b]{2}{*}{ Lane Group } & \multicolumn{3}{|c|}{ AM - Baseline } & \multicolumn{3}{|c|}{ AM - Optimized 1} & \multicolumn{2}{|c|}{ Difference } \\
\hline & v/c Ratio & Total Delay & $\begin{array}{c}\text { Level of } \\
\text { Service (LOS) }\end{array}$ & v/c Ratio & Total Delay & $\begin{array}{c}\text { Level of } \\
\text { Service (LOS) }\end{array}$ & v/c Ratio & Total Delay \\
\hline \multicolumn{9}{|l|}{ EBL } \\
\hline \multicolumn{9}{|l|}{ EBT } \\
\hline \multicolumn{9}{|l|}{ EBR } \\
\hline \multicolumn{9}{|l|}{ WBL } \\
\hline WBT & 0.97 & 44.1 & $\bar{D}$ & 0.83 & 17.2 & $B$ & -0.14 & -26.9 \\
\hline \multicolumn{9}{|l|}{ WBR } \\
\hline \multicolumn{9}{|l|}{ NBL } \\
\hline NBT & 0.83 & 21.3 & $\mathrm{C}$ & 0.89 & 29.5 & $\mathrm{C}$ & 0.06 & 8.2 \\
\hline \multicolumn{9}{|l|}{ NBR } \\
\hline \multicolumn{9}{|l|}{ SBL } \\
\hline SBT & 0.67 & 21.4 & C & 0.68 & 24.9 & C & 0.01 & 3.5 \\
\hline \multicolumn{9}{|l|}{ SBR } \\
\hline & & & & & & & & \\
\hline & & & & & & & & \\
\hline & & & & & & & & \\
\hline & & & & & & & & \\
\hline & & & & & & & & \\
\hline & & & & & & & & \\
\hline
\end{tabular}




\begin{tabular}{|c|c|c|c|c|c|c|c|c|}
\hline \multicolumn{9}{|c|}{ 71: York \& Wellington St } \\
\hline \multirow[b]{2}{*}{ Lane Group } & \multicolumn{3}{|c|}{ AM - Baseline } & \multicolumn{3}{|c|}{ AM - Optimized 1} & \multicolumn{2}{|c|}{ Difference } \\
\hline & v/c Ratio & Total Delay & $\begin{array}{c}\text { Level of } \\
\text { Service (LOS) }\end{array}$ & v/c Ratio & Total Delay & $\begin{array}{c}\text { Level of } \\
\text { Service (LOS) }\end{array}$ & v/c Ratio & Total Delay \\
\hline \multicolumn{9}{|l|}{ EBL } \\
\hline \multicolumn{9}{|l|}{ EBT } \\
\hline \multicolumn{9}{|l|}{ EBR } \\
\hline \multicolumn{9}{|l|}{ WBL } \\
\hline WBT & 0.73 & 12 & B & 0.73 & 8.4 & A & 0 & -3.6 \\
\hline \multicolumn{9}{|l|}{ WBR } \\
\hline \multicolumn{9}{|l|}{ NBL } \\
\hline NBT & 0.67 & 17.1 & B & 0.65 & 17.9 & $B$ & -0.02 & 0.8 \\
\hline \multicolumn{9}{|l|}{ NBR } \\
\hline \multicolumn{9}{|l|}{ SBL } \\
\hline \multicolumn{9}{|l|}{ SBT } \\
\hline \multicolumn{9}{|l|}{ SBR } \\
\hline & & & & & & & & \\
\hline & & & & & & & & \\
\hline & & & & & & & & \\
\hline & & & & & & & & \\
\hline & & & & & & & & \\
\hline & & & & & & & & \\
\hline
\end{tabular}

\begin{tabular}{|c|c|c|c|c|c|c|c|c|}
\hline \multicolumn{9}{|c|}{ 76: University ave \& Wellington St } \\
\hline \multirow[b]{2}{*}{ Lane Group } & \multicolumn{3}{|c|}{ AM - Baseline } & \multicolumn{3}{|c|}{ AM - Optimized 1} & \multicolumn{2}{|c|}{ Difference } \\
\hline & v/c Ratio & Total Delay & $\begin{array}{c}\text { Level of } \\
\text { Service (LOS) }\end{array}$ & v/c Ratio & Total Delay & $\begin{array}{c}\text { Level of } \\
\text { Service (LOS) }\end{array}$ & v/c Ratio & Total Delay \\
\hline \multicolumn{9}{|l|}{ EBL } \\
\hline \multicolumn{9}{|l|}{ EBT } \\
\hline \multicolumn{9}{|l|}{ EBR } \\
\hline \multicolumn{9}{|l|}{ WBL } \\
\hline WBT & 0.46 & 27.1 & $\mathrm{C}$ & 0.46 & 27.1 & $\mathrm{C}$ & 0 & 0 \\
\hline WBR & & & & & & & & 0 \\
\hline NBL & & & & & & & 0 & 0 \\
\hline NBT & 0.63 & 17.1 & $\mathrm{~B}$ & 0.63 & 17.1 & B & 0 & 0 \\
\hline NBR & & & & & & & 0 & 0 \\
\hline SBL & & & & & & & 0 & 0 \\
\hline SBT & 0.72 & 25.9 & C & 0.72 & 25.9 & C & 0 & 0 \\
\hline \multicolumn{9}{|l|}{ SBR } \\
\hline & & & & & & & & \\
\hline & & & & & & & & \\
\hline & & & & & & & & \\
\hline & & & & & & & & \\
\hline & & & & & & & & \\
\hline
\end{tabular}




\begin{tabular}{|c|c|c|c|c|c|c|c|c|}
\hline \multirow[b]{3}{*}{ Lane Group } & \multicolumn{7}{|c|}{ 264: Simcoe \& Wellington St } & \\
\hline & \multicolumn{3}{|c|}{ AM - Baseline } & \multicolumn{3}{|c|}{ AM - Optimized 1} & \multicolumn{2}{|c|}{ Difference } \\
\hline & v/c Ratio & Total Delay & $\begin{array}{c}\text { Level of } \\
\text { Service (LOS) }\end{array}$ & v/c Ratio & Total Delay & $\begin{array}{c}\text { Level of } \\
\text { Service (LOS) }\end{array}$ & v/c Ratio & Total Delay \\
\hline \multicolumn{9}{|l|}{ EBL } \\
\hline \multicolumn{9}{|l|}{ EBT } \\
\hline EBR & 1.12 & 98.6 & $\mathrm{~F}$ & 0.77 & 21.1 & C & -0.35 & -77.5 \\
\hline \multicolumn{9}{|l|}{ WBL } \\
\hline WBT & 0.44 & 11.6 & B & 0.52 & 17.9 & B & 0.08 & 6.3 \\
\hline \multicolumn{9}{|l|}{ WBR } \\
\hline NBL & 0.61 & 39.1 & $\mathrm{D}$ & 0.37 & 17.8 & $\mathrm{C}$ & 0.37 & -21.3 \\
\hline \multicolumn{9}{|l|}{ NBT } \\
\hline \multicolumn{9}{|l|}{ NBR } \\
\hline \multicolumn{9}{|l|}{ SBL } \\
\hline SBT & 0.8 & 37.3 & D & 0.89 & 52.7 & D & 0.09 & 15.4 \\
\hline \multicolumn{9}{|l|}{ SBR } \\
\hline & & & & & & & & \\
\hline & & & & & & & & \\
\hline & & & & & & & & \\
\hline & & & & & & & & \\
\hline & & & & & & & & \\
\hline & & & & & & & & \\
\hline
\end{tabular}

\begin{tabular}{|c|c|c|c|c|c|c|c|c|}
\hline \multicolumn{9}{|c|}{ 1489: John \& Wellington St } \\
\hline \multirow[b]{2}{*}{ Lane Group } & \multicolumn{3}{|c|}{ AM - Baseline } & \multicolumn{3}{|c|}{ AM - Optimized 1} & \multicolumn{2}{|c|}{ Difference } \\
\hline & v/c Ratio & Total Delay & $\begin{array}{c}\text { Level of } \\
\text { Service (LOS) }\end{array}$ & v/c Ratio & Total Delay & $\begin{array}{c}\text { Level of } \\
\text { Service (LOS) }\end{array}$ & v/c Ratio & Total Delay \\
\hline \multicolumn{9}{|l|}{ EBL } \\
\hline \multicolumn{9}{|l|}{ EBT } \\
\hline \multicolumn{9}{|l|}{ EBR } \\
\hline \multicolumn{9}{|l|}{ WBL } \\
\hline WBT & 0.4 & 16.8 & $B$ & 0.48 & 10.7 & $B$ & 0.08 & -6.1 \\
\hline \multicolumn{9}{|l|}{ WBR } \\
\hline \multicolumn{9}{|l|}{ NBL } \\
\hline NBT & 0.97 & 42 & $\mathrm{D}$ & 0.83 & 20.2 & C & -0.14 & -21.8 \\
\hline \multicolumn{9}{|l|}{ NBR } \\
\hline \multicolumn{9}{|l|}{ SBL } \\
\hline SBT & 0.82 & 35.9 & $\mathrm{D}$ & 0.59 & 20.2 & C & -0.23 & -15.7 \\
\hline \multicolumn{9}{|l|}{ SBR } \\
\hline & & & & & & & & \\
\hline & & & & & & & & \\
\hline & & & & & & & & \\
\hline & & & & & & & & \\
\hline
\end{tabular}




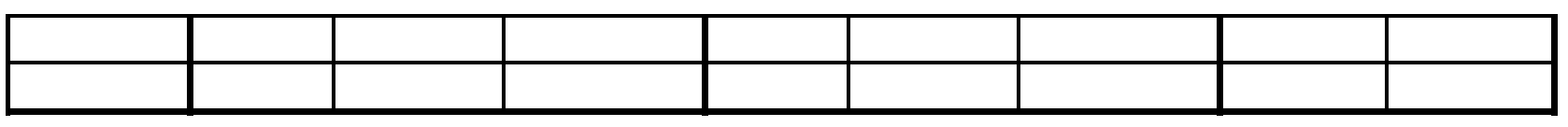

\begin{tabular}{|c|c|c|c|c|c|c|c|c|}
\hline \multicolumn{9}{|c|}{ 1682: Blue Jays Way \& Wellington St } \\
\hline \multirow[b]{2}{*}{ Lane Group } & \multicolumn{3}{|c|}{ AM - Baseline } & \multicolumn{3}{|c|}{ AM - Optimized 1} & \multicolumn{2}{|c|}{ Difference } \\
\hline & v/c Ratio & Total Delay & $\begin{array}{c}\text { Level of } \\
\text { Service (LOS) }\end{array}$ & v/c Ratio & Total Delay & $\begin{array}{c}\text { Level of } \\
\text { Service (LOS) }\end{array}$ & v/c Ratio & Total Delay \\
\hline EBL & 0.49 & 49.7 & $\bar{D}$ & 0.59 & 63.2 & $\mathrm{E}$ & 0.1 & 13.5 \\
\hline EBT & & & & & & & 0 & 0 \\
\hline EBR & 0.21 & 2.5 & $A$ & 0.45 & 46.2 & $\bar{D}$ & 0.24 & 43.7 \\
\hline WBL & 0.61 & 46.6 & $\bar{D}$ & 0.58 & 23.5 & C & -0.03 & -23.1 \\
\hline WBT & 0.29 & 23.6 & C & 0.27 & 1.3 & $A$ & -0.02 & -22.3 \\
\hline WBR & & & & & & & 0 & 0 \\
\hline NBL & & & & & & & 0 & 0 \\
\hline NBT & 0.66 & 24 & C & 0.74 & 29.7 & $C$ & 0.08 & 5.7 \\
\hline NBR & & & & & & & 0 & 0 \\
\hline SBL & & & & & & & 0 & 0 \\
\hline SBT & 0.35 & 18.1 & $B$ & 0.39 & 21.6 & $C$ & 0.04 & 3.5 \\
\hline \multicolumn{9}{|l|}{ SBR } \\
\hline & & & & & & & & \\
\hline & & & & & & & & \\
\hline & & & & & & & & \\
\hline & & & & & & & & \\
\hline & & & & & & & & \\
\hline & & & & & & & & \\
\hline
\end{tabular}




\begin{tabular}{|c|c|c|c|c|c|c|c|c|}
\hline \multicolumn{9}{|c|}{ 15: Church \& Wellingtone St } \\
\hline \multirow[b]{2}{*}{ Lane Group } & \multicolumn{3}{|c|}{ OFF - Baseline } & \multicolumn{3}{|c|}{ OFF - Optimized 1} & \multicolumn{2}{|c|}{ Difference } \\
\hline & v/c Ratio & Total Delay & $\begin{array}{c}\text { Level of } \\
\text { Service (LOS) }\end{array}$ & v/c Ratio & Total Delay & $\begin{array}{c}\text { Level of } \\
\text { Service (LOS) }\end{array}$ & v/c Ratio & Total Delay \\
\hline EBL & 0.61 & 40.3 & $\mathrm{D}$ & 0.61 & 40.3 & $\mathrm{D}$ & 0 & 0 \\
\hline EBT & 0.67 & 36.2 & $\mathrm{D}$ & 0.67 & 36.2 & $\mathrm{D}$ & 0 & 0 \\
\hline EBR & 0.16 & 1.2 & $A$ & 0.16 & 1.2 & $A$ & 0 & 0 \\
\hline WBL & 0.18 & 27.9 & $\mathrm{C}$ & 0.18 & 27.9 & $\mathrm{C}$ & 0 & 0 \\
\hline WBT & 0.62 & 33.9 & C & 0.62 & 33.9 & C & 0 & 0 \\
\hline WBR & 0.32 & 4.2 & $A$ & 0.32 & 4.2 & $A$ & 0 & 0 \\
\hline \multicolumn{9}{|l|}{ NBL } \\
\hline NBT & 0.34 & 23.7 & $\mathrm{C}$ & 0.34 & 23.7 & C & 0 & 0 \\
\hline \multicolumn{9}{|l|}{ NBR } \\
\hline \multicolumn{9}{|l|}{ SBL } \\
\hline SBT & 0.71 & 25.4 & $C$ & 0.71 & 25.4 & C & 0 & 0 \\
\hline \multicolumn{9}{|l|}{ SBR } \\
\hline & & & & & & & & \\
\hline & & & & & & & & \\
\hline & & & & & & & & \\
\hline & & & & & & & & \\
\hline & & & & & & & & \\
\hline & & & & & & & & \\
\hline
\end{tabular}

\begin{tabular}{|c|c|c|c|c|c|c|c|c|}
\hline \multicolumn{9}{|c|}{ 30: Yonge \& Wellingtone St } \\
\hline \multirow[b]{2}{*}{ Lane Group } & \multicolumn{3}{|c|}{ OFF - Baseline } & \multicolumn{3}{|c|}{ OFF - Optimized 1} & \multicolumn{2}{|c|}{ Difference } \\
\hline & v/c Ratio & Total Delay & $\begin{array}{c}\text { Level of } \\
\text { Service (LOS) }\end{array}$ & v/c Ratio & Total Delay & $\begin{array}{c}\text { Level of } \\
\text { Service (LOS) }\end{array}$ & v/c Ratio & Total Delay \\
\hline \multicolumn{9}{|l|}{ EBL } \\
\hline \multicolumn{9}{|l|}{ EBT } \\
\hline \multicolumn{9}{|l|}{ EBR } \\
\hline \multicolumn{9}{|l|}{ WBL } \\
\hline WBT & 0.51 & 23 & $C$ & 0.51 & 23 & C & 0 & 0 \\
\hline \multicolumn{9}{|l|}{ WBR } \\
\hline \multicolumn{9}{|l|}{ NBL } \\
\hline NBT & 0.61 & 14.2 & B & 0.61 & 14.2 & B & 0 & 0 \\
\hline \multicolumn{9}{|l|}{ NBR } \\
\hline \multicolumn{9}{|l|}{ SBL } \\
\hline SBT & 0.54 & 15.9 & B & 0.54 & 15.9 & B & 0 & 0 \\
\hline \multicolumn{9}{|l|}{ SBR } \\
\hline & & & & & & & & \\
\hline & & & & & & & & \\
\hline & & & & & & & & \\
\hline & & & & & & & & \\
\hline & & & & & & & & \\
\hline & & & & & & & & \\
\hline
\end{tabular}




\begin{tabular}{|c|c|c|c|c|c|c|c|c|}
\hline \multicolumn{9}{|c|}{ 60: Bay \& Wellingtone St } \\
\hline \multirow[b]{2}{*}{ Lane Group } & \multicolumn{3}{|c|}{ OFF - Baseline } & \multicolumn{3}{|c|}{ OFF - Optimized 1} & \multicolumn{2}{|c|}{ Difference } \\
\hline & v/c Ratio & Total Delay & $\begin{array}{c}\text { Level of } \\
\text { Service (LOS) }\end{array}$ & v/c Ratio & Total Delay & $\begin{array}{c}\text { Level of } \\
\text { Service (LOS) }\end{array}$ & v/c Ratio & Total Delay \\
\hline \multicolumn{9}{|l|}{ EBL } \\
\hline \multicolumn{9}{|l|}{ EBT } \\
\hline \multicolumn{9}{|l|}{ EBR } \\
\hline \multicolumn{9}{|l|}{ WBL } \\
\hline WBT & 0.55 & 17.5 & $B$ & 0.59 & 16.1 & B & 0.04 & -1.4 \\
\hline \multicolumn{9}{|l|}{ WBR } \\
\hline \multicolumn{9}{|l|}{ NBL } \\
\hline NBT & 0.66 & 17.8 & B & 0.58 & 16.3 & B & -0.08 & -1.5 \\
\hline \multicolumn{9}{|l|}{ NBR } \\
\hline \multicolumn{9}{|l|}{ SBL } \\
\hline SBT & 0.64 & 16.6 & B & 0.56 & 15.5 & B & -0.08 & -1.1 \\
\hline \multicolumn{9}{|l|}{ SBR } \\
\hline & & & & & & & & \\
\hline & & & & & & & & \\
\hline & & & & & & & & \\
\hline & & & & & & & & \\
\hline & & & & & & & & \\
\hline & & & & & & & & \\
\hline
\end{tabular}




\begin{tabular}{|c|c|c|c|c|c|c|c|c|}
\hline \multicolumn{9}{|c|}{ 71: York \& Wellingtone St } \\
\hline \multirow[b]{2}{*}{ Lane Group } & \multicolumn{3}{|c|}{ OFF - Baseline } & \multicolumn{3}{|c|}{ OFF - Optimized 1} & \multicolumn{2}{|c|}{ Difference } \\
\hline & v/c Ratio & Total Delay & $\begin{array}{c}\text { Level of } \\
\text { Service (LOS) }\end{array}$ & v/c Ratio & Total Delay & $\begin{array}{c}\text { Level of } \\
\text { Service (LOS) }\end{array}$ & v/c Ratio & Total Delay \\
\hline \multicolumn{9}{|l|}{ EBL } \\
\hline \multicolumn{9}{|l|}{ EBT } \\
\hline \multicolumn{9}{|l|}{ EBR } \\
\hline \multicolumn{9}{|l|}{ WBL } \\
\hline WBT & 0.5 & 10 & $B$ & 0.48 & 8.9 & A & -0.02 & -1.1 \\
\hline \multicolumn{9}{|l|}{ WBR } \\
\hline \multicolumn{9}{|l|}{ NBL } \\
\hline NBT & 0.48 & 14.8 & B & 0.47 & 17.3 & B & -0.01 & 2.5 \\
\hline \multicolumn{9}{|l|}{ NBR } \\
\hline \multicolumn{9}{|l|}{ SBL } \\
\hline \multicolumn{9}{|l|}{ SBT } \\
\hline \multicolumn{9}{|l|}{ SBR } \\
\hline & & & & & & & & \\
\hline & & & & & & & & \\
\hline & & & & & & & & \\
\hline & & & & & & & & \\
\hline & & & & & & & & \\
\hline & & & & & & & & \\
\hline
\end{tabular}

\begin{tabular}{|c|c|c|c|c|c|c|c|c|}
\hline \multicolumn{9}{|c|}{ 76: University \& Wellingtone St } \\
\hline \multirow[b]{2}{*}{ Lane Group } & \multicolumn{3}{|c|}{ OFF - Baseline } & \multicolumn{3}{|c|}{ OfF - Optimized 1} & \multicolumn{2}{|c|}{ Difference } \\
\hline & v/c Ratio & Total Delay & $\begin{array}{c}\text { Level of } \\
\text { Service (LOS) }\end{array}$ & v/c Ratio & Total Delay & $\begin{array}{c}\text { Level of } \\
\text { Service (LOS) }\end{array}$ & v/c Ratio & Total Delay \\
\hline \multicolumn{9}{|l|}{ EBL } \\
\hline \multicolumn{9}{|l|}{ EBT } \\
\hline \multicolumn{9}{|l|}{ EBR } \\
\hline \multicolumn{9}{|l|}{ WBL } \\
\hline WBT & 0.46 & 25.5 & $\mathrm{C}$ & 0.46 & 25.5 & $\mathrm{C}$ & 0 & 0 \\
\hline \multicolumn{9}{|l|}{ WBR } \\
\hline \multicolumn{9}{|l|}{ NBL } \\
\hline NBT & 0.48 & 14.3 & $B$ & 0.48 & 14.3 & $B$ & 0 & 0 \\
\hline \multicolumn{9}{|l|}{ NBR } \\
\hline \multicolumn{9}{|l|}{ SBL } \\
\hline SBT & 0.59 & 15.7 & B & 0.59 & 15.7 & B & 0 & 0 \\
\hline \multicolumn{9}{|l|}{ SBR } \\
\hline & & & & & & & & \\
\hline & & & & & & & & \\
\hline & & & & & & & & \\
\hline & & & & & & & & \\
\hline & & & & & & & & \\
\hline
\end{tabular}




\begin{tabular}{|c|c|c|c|c|c|c|c|c|}
\hline \multirow[b]{3}{*}{ Lane Group } & \multicolumn{6}{|c|}{ 264: Simcoe \& Wellingtone St } & & \\
\hline & \multicolumn{3}{|c|}{ OFF - Baseline } & \multicolumn{3}{|c|}{ OFF - Optimized 1} & \multicolumn{2}{|c|}{ Difference } \\
\hline & v/c Ratio & Total Delay & $\begin{array}{c}\text { Level of } \\
\text { Service (LOS) }\end{array}$ & v/c Ratio & Total Delay & $\begin{array}{c}\text { Level of } \\
\text { Service (LOS) }\end{array}$ & v/c Ratio & Total Delay \\
\hline \multicolumn{9}{|l|}{ EBL } \\
\hline \multicolumn{9}{|l|}{ EBT } \\
\hline EBR & 0.18 & 1.2 & $A$ & 0.1 & 0.8 & $A$ & -0.08 & -0.4 \\
\hline WBL & & & & & & & 0 & \\
\hline WBT & 0.3 & 12 & B & 0.35 & 17 & B & 0.05 & 5 \\
\hline WBR & & & & & & & 0 & \\
\hline NBL & 0.53 & 29.1 & $\mathrm{C}$ & 0.37 & 16.4 & $B$ & -0.16 & -12.7 \\
\hline \multicolumn{9}{|l|}{ NBT } \\
\hline \multicolumn{9}{|l|}{ NBR } \\
\hline \multicolumn{9}{|l|}{ SBL } \\
\hline SBT & 0.66 & 24.5 & $\mathrm{C}$ & 0.79 & 39.5 & $\mathrm{D}$ & 0.13 & 15 \\
\hline \multicolumn{9}{|l|}{ SBR } \\
\hline & & & & & & & & \\
\hline & & & & & & & & \\
\hline & & & & & & & & \\
\hline & & & & & & & & \\
\hline & & & & & & & & \\
\hline & & & & & & & & \\
\hline
\end{tabular}

\begin{tabular}{|c|c|c|c|c|c|c|c|c|}
\hline \multicolumn{9}{|c|}{ 1489: John \& Wellingtone St } \\
\hline \multirow[b]{2}{*}{ Lane Group } & \multicolumn{3}{|c|}{ OFF - Baseline } & \multicolumn{3}{|c|}{ OFF - Optimized 1} & \multicolumn{2}{|c|}{ Difference } \\
\hline & v/c Ratio & Total Delay & $\begin{array}{c}\text { Level of } \\
\text { Service (LOS) }\end{array}$ & v/c Ratio & Total Delay & $\begin{array}{c}\text { Level of } \\
\text { Service (LOS) }\end{array}$ & v/c Ratio & Total Delay \\
\hline \multicolumn{9}{|l|}{ EBL } \\
\hline \multicolumn{9}{|l|}{ EBT } \\
\hline \multicolumn{9}{|l|}{ EBR } \\
\hline \multicolumn{9}{|l|}{ WBL } \\
\hline WBT & 0.42 & 9.1 & A & 0.43 & 12.2 & B & 0.01 & 3.1 \\
\hline \multicolumn{9}{|l|}{ WBR } \\
\hline \multicolumn{9}{|l|}{ NBL } \\
\hline NBT & 0.42 & 17.6 & $B$ & 0.41 & 18.9 & $B$ & -0.01 & 1.3 \\
\hline \multicolumn{9}{|l|}{ NBR } \\
\hline \multicolumn{9}{|l|}{ SBL } \\
\hline SBT & 0.39 & 18.9 & $B$ & 0.37 & 20 & B & -0.02 & 1.1 \\
\hline \multicolumn{9}{|l|}{ SBR } \\
\hline & & & & & & & & \\
\hline & & & & & & & & \\
\hline & & & & & & & & \\
\hline & & & & & & & & \\
\hline
\end{tabular}




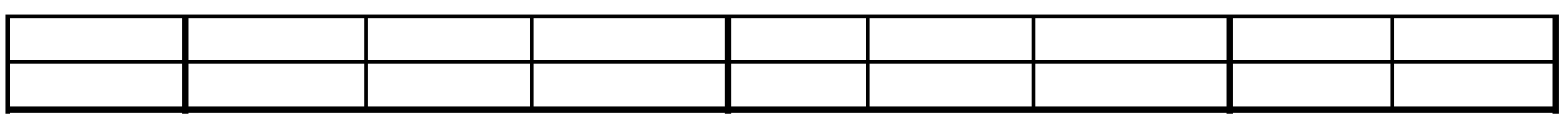

\begin{tabular}{|c|c|c|c|c|c|c|c|c|}
\hline \multicolumn{9}{|c|}{ 1682: Blue Jays Way \& Wellingtone St } \\
\hline \multirow[b]{2}{*}{ Lane Group } & \multicolumn{3}{|c|}{ OFF - Baseline } & \multicolumn{3}{|c|}{ OfF - Optimized 1} & \multicolumn{2}{|c|}{ Difference } \\
\hline & v/c Ratio & Total Delay & $\begin{array}{c}\text { Level of } \\
\text { Service (LOS) }\end{array}$ & v/c Ratio & Total Delay & $\begin{array}{c}\text { Level of } \\
\text { Service (LOS) }\end{array}$ & v/c Ratio & Total Delay \\
\hline EBL & 0.25 & 35 & $\mathrm{C}$ & 0.31 & 41.9 & $\bar{D}$ & 0.06 & 6.9 \\
\hline \multicolumn{9}{|l|}{ EBT } \\
\hline EBR & 0.16 & 1.8 & A & 0.17 & 2 & A & 0.01 & 0.2 \\
\hline WBL & 0.88 & 61.1 & $\mathrm{E}$ & 0.81 & 42.7 & $\mathrm{D}$ & -0.07 & -18.4 \\
\hline WBT & 0.35 & 12.8 & $\mathrm{~B}$ & 0.31 & 3.3 & $\mathrm{~A}$ & -0.04 & -9.5 \\
\hline \multicolumn{9}{|l|}{ WBR } \\
\hline \multicolumn{9}{|l|}{ NBL } \\
\hline NBT & 0.31 & 18.6 & $B$ & 0.34 & 21.9 & $\mathrm{C}$ & 0.03 & 3.3 \\
\hline \multicolumn{9}{|l|}{ NBR } \\
\hline \multicolumn{9}{|l|}{ SBL } \\
\hline SBT & 0.36 & 18.4 & $B$ & 0.39 & 21.8 & $C$ & 0.03 & 3.4 \\
\hline \multicolumn{9}{|l|}{ SBR } \\
\hline & & & & & & & & \\
\hline & & & & & & & & \\
\hline & & & & & & & & \\
\hline & & & & & & & & \\
\hline & & & & & & & & \\
\hline & & & & & & & & \\
\hline
\end{tabular}




\begin{tabular}{|c|c|c|c|c|c|c|c|c|}
\hline \multicolumn{9}{|c|}{ 15: Church \& Wellington St } \\
\hline \multirow[b]{2}{*}{ Lane Group } & \multicolumn{3}{|c|}{ PM - Baseline } & \multicolumn{3}{|c|}{ PM - Optimized 1} & \multicolumn{2}{|c|}{ Difference } \\
\hline & v/c Ratio & Total Delay & $\begin{array}{c}\text { Level of } \\
\text { Service (LOS) }\end{array}$ & v/c Ratio & Total Delay & $\begin{array}{c}\text { Level of } \\
\text { Service (LOS) }\end{array}$ & v/c Ratio & Total Delay \\
\hline EBL & 0.57 & 37.8 & D & 0.57 & 37.8 & D & 0 & 0 \\
\hline EBT & 1.7 & 346.9 & $\mathrm{~F}$ & 1.7 & 346.9 & $\mathrm{~F}$ & 0 & 0 \\
\hline EBR & 0.16 & 1.3 & $A$ & 0.16 & 1.3 & $A$ & 0 & 0 \\
\hline WBL & 0.13 & 27 & C & 0.13 & 27 & C & 0 & 0 \\
\hline WBT & 0.69 & 35.6 & $\mathrm{D}$ & 0.69 & 35.6 & $\mathrm{D}$ & 0 & 0 \\
\hline WBR & 0.32 & 4.2 & A & 0.32 & 4.2 & A & 0 & 0 \\
\hline \multicolumn{9}{|l|}{ NBL } \\
\hline NBT & 0.66 & 31.4 & C & 0.66 & 31.4 & C & 0 & 0 \\
\hline \multicolumn{9}{|l|}{ NBR } \\
\hline \multicolumn{9}{|l|}{ SBL } \\
\hline SBT & 1.36 & 198.2 & $\mathrm{~F}$ & 1.36 & 198.2 & $\mathrm{~F}$ & 0 & 0 \\
\hline \multicolumn{9}{|l|}{ SBR } \\
\hline & & & & & & & & \\
\hline & & & & & & & & \\
\hline & & & & & & & & \\
\hline & & & & & & & & \\
\hline & & & & & & & & \\
\hline & & & & & & & & \\
\hline
\end{tabular}

\begin{tabular}{|c|c|c|c|c|c|c|c|c|}
\hline \multicolumn{9}{|c|}{ 30: Yonge \& Wellington St } \\
\hline \multirow[b]{2}{*}{ Lane Group } & \multicolumn{3}{|c|}{ PM - Baseline } & \multicolumn{3}{|c|}{ PM - Optimized 1} & \multicolumn{2}{|c|}{ Difference } \\
\hline & v/c Ratio & Total Delay & $\begin{array}{c}\text { Level of } \\
\text { Service (LOS) }\end{array}$ & v/c Ratio & Total Delay & $\begin{array}{c}\text { Level of } \\
\text { Service (LOS) }\end{array}$ & v/c Ratio & Total Delay \\
\hline \multicolumn{9}{|l|}{ EBL } \\
\hline \multicolumn{9}{|l|}{ EBT } \\
\hline \multicolumn{9}{|l|}{ EBR } \\
\hline \multicolumn{9}{|l|}{ WBL } \\
\hline WBT & 0.66 & 28.3 & C & 0.66 & 28.3 & C & 0 & 0 \\
\hline WBR & & & & & & & 0 & \\
\hline NBL & & & & & & & 0 & \\
\hline NBT & 0.51 & 11.7 & B & 0.51 & 11.7 & B & 0 & 0 \\
\hline NBR & & & & & & & 0 & \\
\hline SBL & & & & & & & 0 & \\
\hline SBT & 0.44 & 14.3 & B & 0.44 & 14.3 & B & 0 & 0 \\
\hline \multicolumn{9}{|l|}{ SBR } \\
\hline & & & & & & & & \\
\hline & & & & & & & & \\
\hline & & & & & & & & \\
\hline & & & & & & & & \\
\hline & & & & & & & & \\
\hline & & & & & & & & \\
\hline
\end{tabular}




\begin{tabular}{|c|c|c|c|c|c|c|c|c|}
\hline \multicolumn{9}{|c|}{ 60: Bay \& Wellington St } \\
\hline \multirow[b]{2}{*}{ Lane Group } & \multicolumn{3}{|c|}{ PM - Baseline } & \multicolumn{3}{|c|}{ PM - Optimized 1} & \multicolumn{2}{|c|}{ Difference } \\
\hline & v/c Ratio & Total Delay & $\begin{array}{c}\text { Level of } \\
\text { Service (LOS) }\end{array}$ & v/c Ratio & Total Delay & $\begin{array}{c}\text { Level of } \\
\text { Service (LOS) }\end{array}$ & v/c Ratio & Total Delay \\
\hline \multicolumn{9}{|l|}{ EBL } \\
\hline \multicolumn{9}{|l|}{ EBT } \\
\hline \multicolumn{9}{|l|}{ EBR } \\
\hline \multicolumn{9}{|l|}{ WBL } \\
\hline WBT & 0.56 & 17.8 & $B$ & 0.58 & 16.2 & $B$ & 0.02 & -1.6 \\
\hline \multicolumn{9}{|l|}{ WBR } \\
\hline \multicolumn{9}{|l|}{ NBL } \\
\hline NBT & 0.46 & 16.8 & $B$ & 0.42 & 16.4 & $B$ & -0.04 & -0.4 \\
\hline \multicolumn{9}{|l|}{ NBR } \\
\hline \multicolumn{9}{|l|}{ SBL } \\
\hline SBT & 0.75 & 22.1 & C & 0.69 & 20.9 & C & -0.06 & -1.2 \\
\hline \multicolumn{9}{|l|}{ SBR } \\
\hline & & & & & & & & \\
\hline & & & & & & & & \\
\hline & & & & & & & & \\
\hline & & & & & & & & \\
\hline & & & & & & & & \\
\hline & & & & & & & & \\
\hline
\end{tabular}




\begin{tabular}{|c|c|c|c|c|c|c|c|c|}
\hline \multicolumn{9}{|c|}{ 71: York \& Wellington St } \\
\hline \multirow[b]{2}{*}{ Lane Group } & \multicolumn{3}{|c|}{ PM - Baseline } & \multicolumn{3}{|c|}{ PM - Optimized 1} & \multicolumn{2}{|c|}{ Difference } \\
\hline & v/c Ratio & Total Delay & $\begin{array}{c}\text { Level of } \\
\text { Service (LOS) }\end{array}$ & v/c Ratio & Total Delay & $\begin{array}{c}\text { Level of } \\
\text { Service (LOS) }\end{array}$ & v/c Ratio & Total Delay \\
\hline \multicolumn{9}{|l|}{ EBL } \\
\hline \multicolumn{9}{|l|}{ EBT } \\
\hline \multicolumn{9}{|l|}{ EBR } \\
\hline \multicolumn{9}{|l|}{ WBL } \\
\hline WBT & 0.82 & 18.1 & B & 0.77 & 14.6 & B & -0.05 & -3.5 \\
\hline \multicolumn{9}{|l|}{ WBR } \\
\hline \multicolumn{9}{|l|}{ NBL } \\
\hline NBT & 0.49 & 15 & B & 0.5 & 17.4 & B & 0.01 & 2.4 \\
\hline \multicolumn{9}{|l|}{ NBR } \\
\hline \multicolumn{9}{|l|}{ SBL } \\
\hline \multicolumn{9}{|l|}{ SBT } \\
\hline \multicolumn{9}{|l|}{ SBR } \\
\hline & & & & & & & & \\
\hline & & & & & & & & \\
\hline & & & & & & & & \\
\hline & & & & & & & & \\
\hline & & & & & & & & \\
\hline & & & & & & & & \\
\hline
\end{tabular}

\begin{tabular}{|c|c|c|c|c|c|c|c|c|}
\hline \multicolumn{9}{|c|}{ 76: University ave \& Wellington St } \\
\hline \multirow[b]{2}{*}{ Lane Group } & \multicolumn{3}{|c|}{ PM - Baseline } & \multicolumn{3}{|c|}{ PM - Optimized 1} & \multicolumn{2}{|c|}{ Difference } \\
\hline & v/c Ratio & Total Delay & $\begin{array}{c}\text { Level of } \\
\text { Service (LOS) }\end{array}$ & v/c Ratio & Total Delay & $\begin{array}{c}\text { Level of } \\
\text { Service (LOS) }\end{array}$ & v/c Ratio & Total Delay \\
\hline \multicolumn{9}{|l|}{ EBL } \\
\hline \multicolumn{9}{|l|}{ EBT } \\
\hline \multicolumn{9}{|l|}{ EBR } \\
\hline \multicolumn{9}{|l|}{ WBL } \\
\hline WBT & 0.57 & 25.7 & $\mathrm{C}$ & 0.57 & 25.7 & $\mathrm{C}$ & 0 & 0 \\
\hline \multicolumn{9}{|l|}{ WBR } \\
\hline \multicolumn{9}{|l|}{ NBL } \\
\hline NBT & 0.47 & 18 & B & 0.47 & 18 & B & 0 & 0 \\
\hline \multicolumn{9}{|l|}{ NBR } \\
\hline \multicolumn{9}{|l|}{ SBL } \\
\hline SBT & 0.71 & 22.5 & C & 0.71 & 22.5 & C & 0 & 0 \\
\hline \multicolumn{9}{|l|}{ SBR } \\
\hline & & & & & & & & \\
\hline & & & & & & & & \\
\hline & & & & & & & & \\
\hline & & & & & & & & \\
\hline & & & & & & & & \\
\hline
\end{tabular}




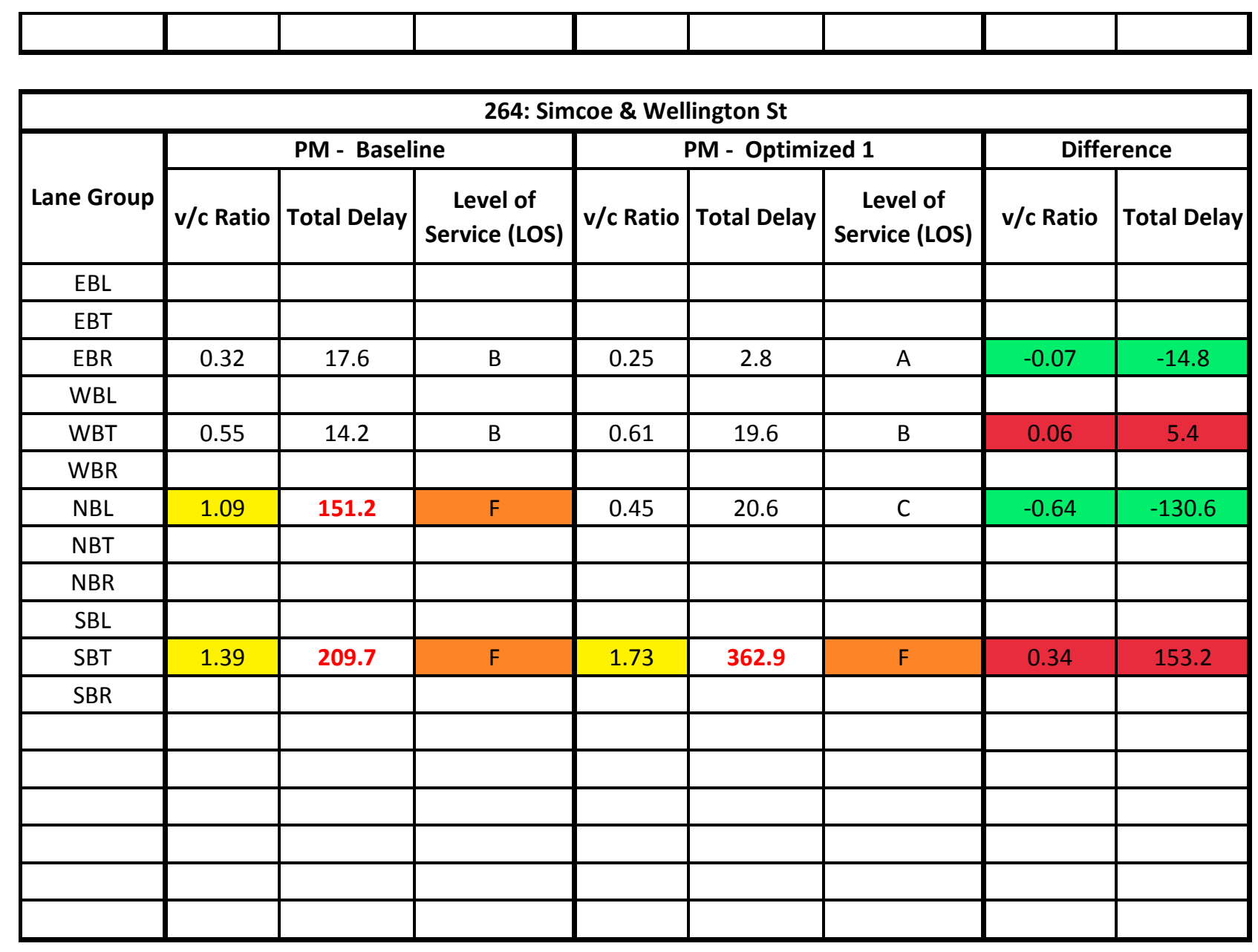

\begin{tabular}{|c|c|c|c|c|c|c|c|c|}
\hline \multicolumn{9}{|c|}{ 1489: John \& Wellington St } \\
\hline \multirow[b]{2}{*}{ Lane Group } & \multicolumn{3}{|c|}{ PM - Baseline } & \multicolumn{3}{|c|}{ PM - Optimized 1} & \multicolumn{2}{|c|}{ Difference } \\
\hline & v/c Ratio & Total Delay & $\begin{array}{c}\text { Level of } \\
\text { Service (LOS) }\end{array}$ & v/c Ratio & Total Delay & $\begin{array}{c}\text { Level of } \\
\text { Service (LOS) }\end{array}$ & v/c Ratio & Total Delay \\
\hline \multicolumn{9}{|l|}{ EBL } \\
\hline \multicolumn{9}{|l|}{ EBT } \\
\hline \multicolumn{9}{|l|}{ EBR } \\
\hline \multicolumn{9}{|l|}{ WBL } \\
\hline WBT & 0.79 & 22.7 & C & 0.77 & 16 & B & -0.02 & -6.7 \\
\hline \multicolumn{9}{|l|}{ WBR } \\
\hline \multicolumn{9}{|l|}{ NBL } \\
\hline NBT & 0.66 & 23.4 & C & 0.65 & 25.5 & C & -0.01 & 2.1 \\
\hline \multicolumn{9}{|l|}{ NBR } \\
\hline \multicolumn{9}{|l|}{ SBL } \\
\hline SBT & 0.62 & 22.5 & C & 0.61 & 24.5 & C & -0.01 & 2 \\
\hline \multicolumn{9}{|l|}{ SBR } \\
\hline & & & & & & & & \\
\hline & & & & & & & & \\
\hline & & & & & & & & \\
\hline & & & & & & & & \\
\hline
\end{tabular}




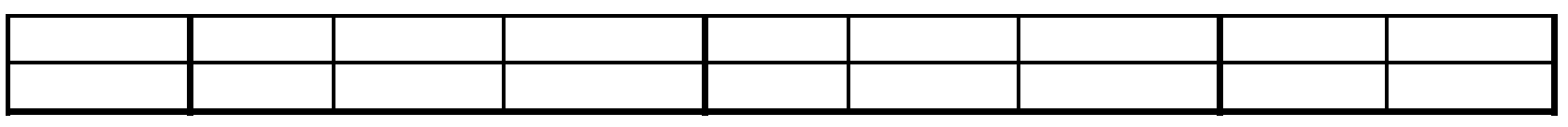

\begin{tabular}{|c|c|c|c|c|c|c|c|c|}
\hline \multicolumn{9}{|c|}{ 1682: Blue Jays Way \& Wellington St } \\
\hline \multirow[b]{2}{*}{ Lane Group } & \multicolumn{3}{|c|}{ PM - Baseline } & \multicolumn{3}{|c|}{ PM - Optimized 1} & \multicolumn{2}{|c|}{ Difference } \\
\hline & v/c Ratio & Total Delay & $\begin{array}{c}\text { Level of } \\
\text { Service (LOS) }\end{array}$ & v/c Ratio & Total Delay & $\begin{array}{c}\text { Level of } \\
\text { Service (LOS) }\end{array}$ & v/c Ratio & Total Delay \\
\hline EBL & 0.25 & 33.8 & C & 0.31 & 40.7 & $\bar{D}$ & 0.06 & 6.9 \\
\hline EBT & & & & & & & 0 & 0 \\
\hline EBR & 0.15 & 1.6 & A & 0.16 & 1.9 & A & 0.01 & 0.3 \\
\hline WBL & 0.91 & 45.7 & D & 0.93 & 49.2 & D & 0.02 & 3.5 \\
\hline WBT & 0.43 & 6.2 & $A$ & 0.43 & 6.7 & $A$ & 0 & 0.5 \\
\hline WBR & & & & & & & 0 & 0 \\
\hline NBL & & & & & & & 0 & 0 \\
\hline NBT & 0.6 & 24.3 & C & 0.58 & 25.9 & $\mathrm{C}$ & -0.02 & 1.6 \\
\hline NBR & & & & & & & 0 & 0 \\
\hline SBL & & & & & & & 0 & 0 \\
\hline SBT & 0.78 & 28.2 & $C$ & 0.75 & 29.4 & $C$ & -0.03 & 1.2 \\
\hline \multicolumn{9}{|l|}{ SBR } \\
\hline & & & & & & & & \\
\hline & & & & & & & & \\
\hline & & & & & & & & \\
\hline & & & & & & & & \\
\hline & & & & & & & & \\
\hline & & & & & & & & \\
\hline
\end{tabular}




\section{APPENDIX G}

Proposed Signal Timing Plans 


\begin{tabular}{|c|c|c|c|c|c|c|c|c|}
\hline \multirow[t]{2}{*}{$\begin{array}{l}\text { LOCATION: } \\
\text { PX: } \\
\text { MODE / COMMENT: } \\
\text { PREPARED / CHECKED BY: } \\
\text { PREPARATION DATE: } \\
\text { IMPLEMENTATION DATE: }\end{array}$} & $\begin{array}{l}\text { Bay St \& Welling } \\
60 \\
\text { FXT with 2-wire } \\
\text { SS/DS } \\
\text { Nov } 03,2015\end{array}$ & $\begin{array}{l}\text { ton St } \\
\text { olara APS }\end{array}$ & & & & & \multirow[t]{2}{*}{$\begin{array}{r}\text { DISTRICT: } \\
\text { COMPUTER SYSTEM: } \\
\text { CONTROLLER/CABINET TYPE: } \\
\text { CONFLICT FLASH: } \\
\text { DESIGN WALK SPEED: } \\
\text { CHANNELIDROP: } \\
\text { CONTROLLER FRIMWARE: }\end{array}$} & \multirow[t]{2}{*}{$\begin{array}{l}\text { Toronto \& East York } \\
\text { TransSuite } \\
\text { Econolite ASC/3-2100 / TS2 T1 } \\
\text { Red \& Red } \\
1.0 \mathrm{~m} / \mathrm{s} \text { (FDW based on full crossing @ } 1.2 \mathrm{~m} / \mathrm{s}) \\
4016 / 2 \\
2.47 .10\end{array}$} \\
\hline & & & & & & & & \\
\hline \multirow[t]{3}{*}{ NEMA Phase } & & $\begin{array}{c}\text { OFF } \\
\text { All Other } \\
\text { Times }\end{array}$ & \begin{tabular}{|c|} 
AM \\
$07: 00-10: 00$ \\
$M-F$
\end{tabular} & \begin{tabular}{|c|} 
PM \\
15:00-19:00 \\
M-F \\
\end{tabular} & $\begin{array}{c}\text { PAM } \\
\text { All Other } \\
\text { Times }\end{array}$ & $\begin{array}{c}\text { Gardiner } \\
\text { Times to be } \\
\text { determined }\end{array}$ & \multirow[t]{2}{*}{$\begin{array}{c}\text { Phase Mode } \\
\text { (Fixed/Demanded/Callable) }\end{array}$} & \multirow[t]{2}{*}{ Remarks } \\
\hline & \begin{tabular}{|l} 
Local Plan \\
System Plan \\
\end{tabular} & $\begin{array}{l}\text { Pattern } 1 \\
\text { Plan 1 } \\
\end{array}$ & $\begin{array}{l}\text { Pattern 2 } \\
\text { Plan 2 } \\
\end{array}$ & $\begin{array}{l}\text { Pattern } 3 \\
\text { Plan 3 } \\
\end{array}$ & $\begin{array}{l}\text { Pattern } 4 \\
\text { Plan } 4 \\
\end{array}$ & $\begin{array}{c}\text { Pattern } 61 \\
\text { Plan } 61 \\
\end{array}$ & & \\
\hline & $\begin{array}{l}\text { WLK } \\
\text { FDW } \\
\text { MIN } \\
\text { MAX1 } \\
\text { AMB } \\
\text { ALR } \\
\text { SPLIT } \\
\end{array}$ & & & & & & & $\begin{array}{l}\text { Pedestrian Minimums: } \\
\text { NSWK }=7 \text { sec., NSFD }=12 \mathrm{sec} . \\
\text { EWWK }=7 \text { sec., EWFD }=12 \text { sec. } \\
\text { APS on during NSWK and EWWK when activated. } \\
\text { APS not on during NBLA. } \\
\text { Extended Push Activation }=3 \text { sec. } \\
\text { NS pushbutton monitored on local detector } 2 \& \\
\text { EW pushbutton monitored on local detector } 6 . \\
\end{array}$ \\
\hline 2 & $\begin{array}{lc}\text { WLK } & 7 \\
\text { FDW } & 12 \\
\text { MIN } & 19 \\
\text { MAX1 } & 38 \\
\text { AMB } & 4 \\
\text { ALR } & 3 \\
\text { SPLIT } & \\
\end{array}$ & 44 & 4 & 43 & 44 & 46 & Fixed & \\
\hline 3 & $\begin{array}{l}\text { WLK } \\
\text { FDW } \\
\text { MIN } \\
\text { MAX1 } \\
\text { AMB } \\
\text { ALR } \\
\text { SPLIT } \\
\end{array}$ & & & & & & & \\
\hline 4 & \begin{tabular}{|lc} 
WLK & 7 \\
FDW & 12 \\
MIN & 19 \\
MAX1 & 20 \\
AMB & 4 \\
ALR & 2 \\
SPLIT & \\
\end{tabular} & 31 & 34 & 37 & 31 & 34 & & \\
\hline 5 & \begin{tabular}{|lr} 
WLK & \\
FDW & \\
MIN & 6 \\
MAX1 & 6 \\
AMB & 3 \\
ALR & 1 \\
SPLIT & \\
\end{tabular} & & 12 & & & & $\begin{array}{c}\text { Fixed NBLA } \\
\text { 7:00-9:30 M-F } \\
\text { (in shared leftthru lane) }\end{array}$ & \\
\hline 6 & $\begin{array}{lc}\text { WLK } & 7 \\
\text { FDW } & 12 \\
\text { MIN } & 19 \\
\text { MAX1 } & 38 \\
\text { AMB } & 4 \\
\text { ALR } & 3 \\
\text { SPLIT } & \\
\end{array}$ & 44 & 34 & 43 & 44 & 46 & Fixed & \\
\hline USED & $\begin{array}{l}\text { WLK } \\
\text { FDW } \\
\text { MIN } \\
\text { MAX1 } \\
\text { AMB } \\
\text { ALR } \\
\text { SPLIT } \\
\end{array}$ & & & & & & & \\
\hline 8 & $\begin{array}{lc}\text { WLK } & 7 \\
\text { FDW } & 12 \\
\text { MIN } & 19 \\
\text { MAX1 } & 20 \\
\text { AMB } & 4 \\
\text { ALR } & 2 \\
\text { SPLIT } & \\
\end{array}$ & 31 & 34 & 37 & 31 & 34 & Fixed & \\
\hline & $\begin{array}{l}\mathrm{CL} \\
\mathrm{OF}\end{array}$ & $\begin{array}{l}75 \\
58\end{array}$ & $\begin{array}{l}80 \\
56\end{array}$ & $\begin{array}{l}80 \\
66\end{array}$ & $\begin{array}{l}75 \\
58\end{array}$ & $\begin{array}{l}80 \\
56\end{array}$ & & \\
\hline
\end{tabular}

Pick up on TransSuite system on Mar 5,2013. 


\begin{tabular}{|c|c|c|c|c|c|c|c|c|}
\hline $\begin{array}{l}\text { LOCATION: } \\
\text { MODE/COMMENT: } \\
\text { PX: } \\
\text { PREPARED/CHECKED BY: } \\
\text { PREPARATION DATE: } \\
\text { IMPLEMENTATION DATE: }\end{array}$ & $\begin{array}{l}\text { York St \& V } \\
\text { FXT } \\
71 \\
\text { SS/DS } \\
\text { Nov } 03,2015\end{array}$ & /ellington S & & & & & $\begin{array}{l}\text { DISTRICT: } \\
\text { COMPUTER SYSTEM: } \\
\text { CONTROLLER/CABINET TYPE: } \\
\text { CONFLICT FLASH: } \\
\text { DESIGN WALK SPEED: } \\
\text { CHANNEL/DROP: } \\
\text { CONTROLLER FRIMWARE: } \\
\end{array}$ & $\begin{array}{l}\text { Toronto \& East York } \\
\text { TransSuite } \\
\text { Econolite ASC/3-2100 / TS2T1 } \\
\text { Red \& Red } \\
1.0 \mathrm{~m} / \mathrm{s} \text { (FDW based on full crossing @ 1.2m/s) } \\
4016 / 9 \\
2.47 .10\end{array}$ \\
\hline \multirow{3}{*}{ NEMA Phase } & & OFF & AM & PM & PAM & & \multirow{3}{*}{$\begin{array}{l}\text { Phase Mode } \\
\text { (Fixed/Demanded } \\
\text { or Callable) }\end{array}$} & \multirow{3}{*}{ Remarks } \\
\hline & & $\begin{array}{c}\text { All Other } \\
\text { Times }\end{array}$ & $\begin{array}{c}\text { 07:00-9:30 } \\
\text { M-F }\end{array}$ & $\begin{array}{c}\text { 15:00-19:00 } \\
\text { M-F }\end{array}$ & $\begin{array}{l}\text { All Other } \\
\text { Times }\end{array}$ & $\begin{array}{l}\text { Gardiner } \\
\text { Closure }\end{array}$ & & \\
\hline & \begin{tabular}{|l|} 
Local Plan \\
System Plan \\
\end{tabular} & \begin{tabular}{|c|} 
Pattern 1 \\
Plan 1 \\
\end{tabular} & $\begin{array}{l}\text { Pattern 2 } \\
\text { Plan 2 }\end{array}$ & $\begin{array}{c}\text { Pattern } 3 \\
\text { Plan } 3\end{array}$ & $\begin{array}{l}\text { Pattern } 4 \\
\text { Plan } 4\end{array}$ & $\begin{array}{c}\text { Pattern } 61 \\
\text { Plan } 61\end{array}$ & & \\
\hline NOT US & $\begin{array}{l}\text { WLK } \\
\text { FDW } \\
\text { MIN } \\
\text { MAX1 } \\
\text { AMB } \\
\text { ALR } \\
\text { SPLIT } \\
\end{array}$ & & & & & & & $\begin{array}{l}\text { Pedestrian Minimums: } \\
\text { NSWK }=7 \mathrm{sec}, \mathrm{NSFD}=14 \mathrm{sec} \\
\text { EWWK }=7 \mathrm{sec}, \mathrm{EWFD}=14 \mathrm{sec} \\
\end{array}$ \\
\hline 2 & \begin{tabular}{|lc} 
WLK & 7 \\
FDW & 14 \\
MIN & 21 \\
MAX1 & 29 \\
AMB & 4 \\
ALR & 2 \\
SPLIT & \\
\end{tabular} & 35 & 44 & 40 & 35 & 44 & Fixed & . \\
\hline 3 & $\begin{array}{l}\text { WLK } \\
\text { FDW } \\
\text { MIN } \\
\text { MAX1 } \\
\text { AMB } \\
\text { ALR } \\
\text { SPLIT } \\
\end{array}$ & & & & & & & \\
\hline 4 & \begin{tabular}{|lc} 
WLK & 7 \\
FDW & 14 \\
MIN & 21 \\
MAX1 & 35 \\
AMB & 4 \\
ALR & 2 \\
SPLIT & \\
\end{tabular} & 40 & 36 & 40 & 40 & 36 & Fixed & . \\
\hline 5 & $\begin{array}{l}\text { WLK } \\
\text { FDW } \\
\text { MIN } \\
\text { MAX1 } \\
\text { AMB } \\
\text { ALR } \\
\text { SPLIT }\end{array}$ & & & & & & & \\
\hline 6 & $\begin{array}{ll}\text { WLK } & 7 \\
\text { FDW } & 14 \\
\text { MIN } & 21 \\
\text { MAX1 } & 29 \\
\text { AMB } & 4 \\
\text { ALR } & 2 \\
\text { SPLIT } & \end{array}$ & 35 & 44 & 40 & 35 & 44 & Fixed & \\
\hline NOT USED & $\begin{array}{l}\text { WLK } \\
\text { FDW } \\
\text { MIN } \\
\text { MAX1 } \\
\text { AMB } \\
\text { ALR } \\
\text { SPLIT } \\
\end{array}$ & & & & & & & \\
\hline 8 & \begin{tabular}{|lc} 
WLK & 7 \\
FDW & 14 \\
MIN & 21 \\
MAX1 & 35 \\
AMB & 4 \\
ALR & 2 \\
SPLIT &
\end{tabular} & 40 & 36 & 40 & 40 & 36 & Fixed & \\
\hline & $\begin{array}{l}\mathrm{CL} \\
\mathrm{OF}\end{array}$ & $\begin{array}{l}75 \\
10\end{array}$ & $\begin{array}{l}80 \\
65\end{array}$ & $\begin{array}{c}80 \\
6\end{array}$ & $\begin{array}{l}75 \\
10\end{array}$ & $\begin{array}{l}80 \\
65\end{array}$ & & \\
\hline
\end{tabular}




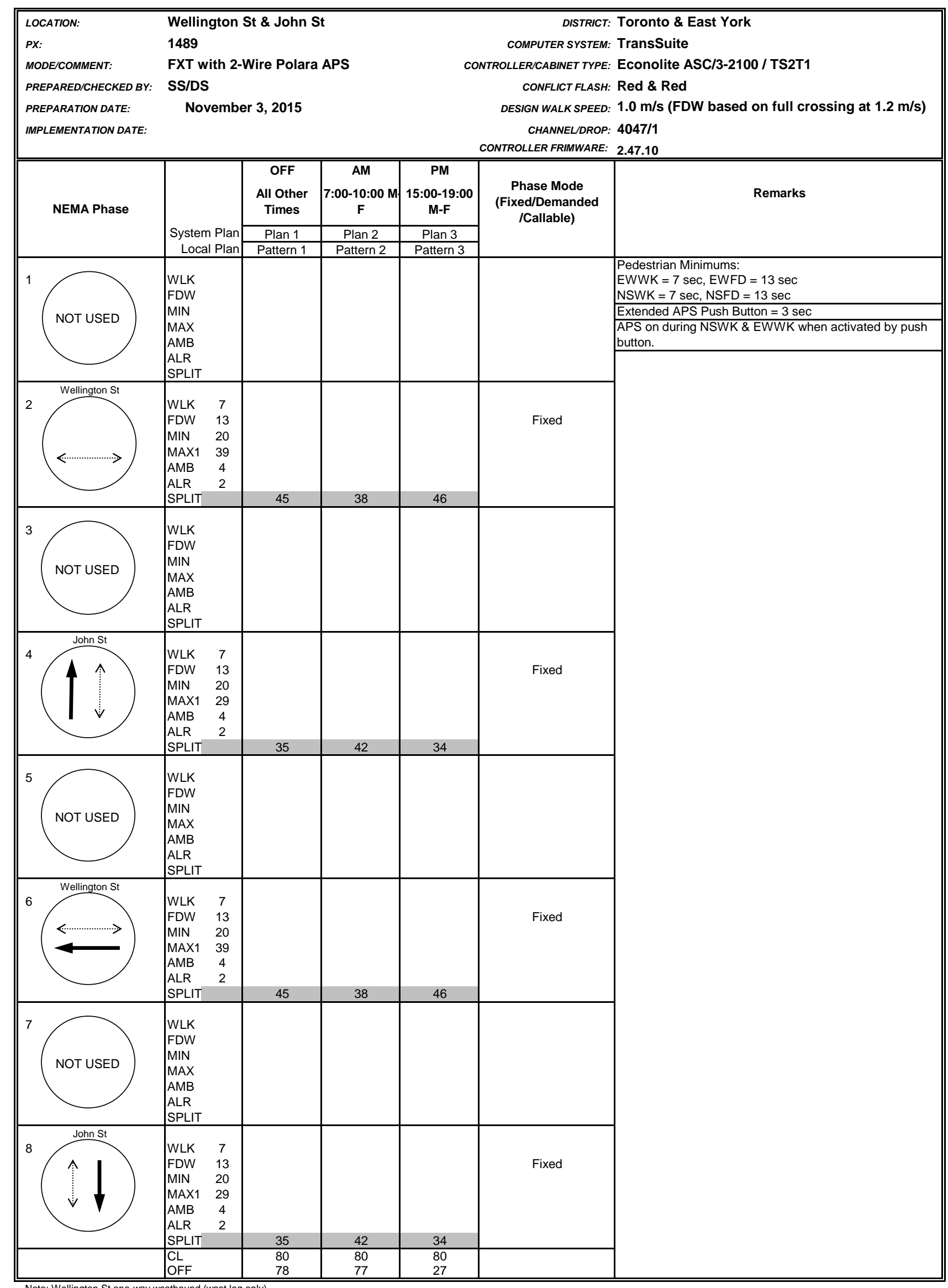

Note: Wellington St one-way westbound (west leg only)

Picked up TransSuite System on April 26, 2013 at 13:03 


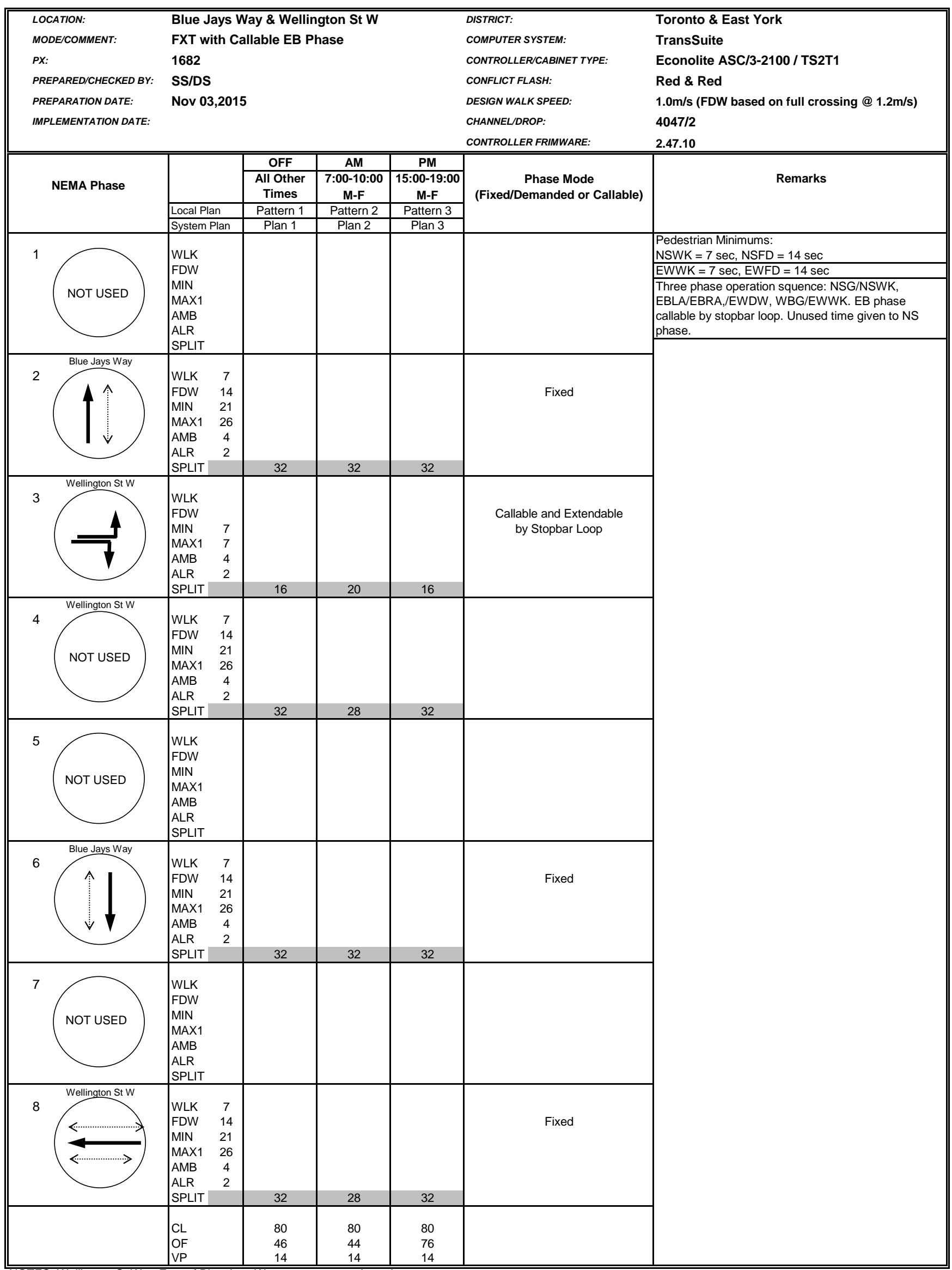




\section{$\underline{\text { References }}$}

[1] "Traffic Control Systems," City of Toronto, [Online]. Available: http://www1.toronto.ca/wps/portal/contentonly?vgnextoid=a6c4fec1181ec410VgnVCM100000 71d60f89RCRD\&vgnextchannel=9452722c231ec410VgnVCM10000071d60f89RCRD. [Accessed $112016]$.

[2] "Mode of Control," City of Toronto, [Online]. Available: http://www1.toronto.ca/wps/portal/contentonly?vgnextoid=d3cc9325bd1ec410VgnVCM10000 071d60f89RCRD\&vgnextchannel=9452722c231ec410VgnVCM10000071d60f89RCRD. [Accessed $112016]$.

[3] "Manual of Transportation Engineering Studies," Institute of Transportation Engineers, 2000, pp. 55-56.

[4] Riniker, K., Silberman, Paul,P.E., P.T.O.E., \& Sabra, Ziad A, PHD,P.E., P.T.O.E., "Signal timing optimization methodologies and challenges for the city of baltimore," Institute of Transportation Engineers.ITE Journal, 2008.

[5] Highway Capacity Manual, Washington DC: Transportation Research Board, 2000.

[6] "Trafficware," [Online]. Available: http://www.trafficware.com/synchro-studio.html.

[7] Highway Capacity Manual, Washington DC: Transportation Research Board, 2010.

[8] "Guidlines for using Synchro 7," City of Toronto, April 2010.

[9] "Michigan Signal Optimization," Michigan Department of Transportation, Michigan, October 2008.

[10] "Annuity Payment (PV)," Finance Formulas, [Online]. Available:

http://www.financeformulas.net/Annuity_Payment_Formula.html. [Accessed 11 2016].

[11] "Signal Optimization (Coordination)," City of Toronto, [Online]. Available: http://www1.toronto.ca/wps/portal/contentonly?vgnextoid=0c9d9325bd1ec410VgnVCM10000 071d60f89RCRD\&vgnextchannel=9452722c231ec410VgnVCM10000071d60f89RCRD. [Accessed $112016]$.

[12] "Toronto Gas Price," [Online]. Available: http://www.torontogasprices.com/. [Accessed 2015].

[13] "F.G. Gardiner Expressway Rehabilitation Project," City of Toronto, January 2016.

[14] Delcan, "GUIDELINES FOR QUANTIFYING VEHICLE EMISSIONS," British Colombia Ministry of Transportation, 2007.

[15] Rakesh B. Singh and James J. Sloan, "DEVELOPMENT AND APPLICATION OFA MICRO SCALE EMISSION," 14th Annual Emission Inventory Conference, Las Vegas, 2005. 